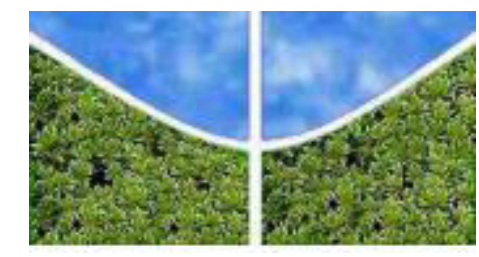

UNIVERSIDADE DE BRASÍLIA

PROGRAMA DE PÓS GRADUAÇÃO EM ZOOLOGIA

\title{
BIOGEOGRAFIA E SISTEMÁTICA DE TRÊS ESPÉCIES DE PEQUENOS MAMÍFEROS (RODENTIA E DIDELPHIMORPHIA) DO CERRADO E CAATINGA
}

LEONARDO FERREIRA MACHADO

BRASÍLIA, OUTUBRO DE 2016 


\section{BIOGEOGRAFIA E SISTEMÁTICA DE TRÊS ESPÉCIES DE PEQUENOS MAMÍFEROS (RODENTIA E DIDELPHIMORPHIA) DO CERRADO E CAATINGA}

LEONARDO FERREIRA MACHADO

TESE APRESENTADA AO PROGRAMA DE PÓS-GRADUAÇÃO EM ZOOLOGIA, DO INSTITUTO DE CIÊNCIAS BIOLÓGICAS DA UNIVERSIDADE DE BRASÍLIA, COMO PARTE DOS REQUISITOS PARA OBTENÇÃO DO TÍTULO DE DOUTOR EM ZOOLOGIA.

ORIENTADOR: PROF. DR. JADER MARINHO-FILHO

BRASÍLIA, OUTUBRO DE 2016 
$\Psi$ Universidade de Brasília

Instituto de Ciências Biológicas

Departamento de Zoologia

Programa de Pós-Graduação em Zoologia

Tese de Doutorado

Leonardo Ferreira Machado

Título:

Biogeografia e sistemática de três espécies de pequenos mamíferos (Rodentia e Didelphimorphia) do Cerrado e Caatinga

Banca Examinadora:

Prof. Dr. Jader Marinho-Filho

Presidente / Orientador

$\mathrm{ZOO} / \mathrm{UnB}$

Prof. Dr. Alexandre Reis Percequilo Membro Titular ESALQ/USP

Prof. Dr. Antônio Aguiar

Membro Titular

$\mathrm{ZOO} / \mathrm{UnB}$
Profa. Dra. Lilian Gimenes Giugliano

Membro Titular

GEM/UnB

Prof. Dr. Eliécer Gutiérrez

Membro Titular

$\mathrm{ZOO} / \mathrm{UnB}$ 
“...o verdadeiro mundo natural, feito de silêncio, caos e noite antiga, prossegue tão hostil e inóspito quanto na aurora dos tempos, maldição a ser combatida com todas as forças e todos os meios, por mais que os discursos vigentes afirmem o contrário. Apenas sua derrota permitirá a plenitude do mito, pois é em torno desse adversário vencido e inerme que se consolida a visão idílica da paisagem natural como um autêntico jardim das delícias, fantasia construída sobre tristes remanescentes domesticados que variam entre a casa de campo, o bosque suburbano e o parque nacional".

Papavero \& Teixeira (2001, p. 1032) ${ }^{1}$

${ }^{1}$ Papavero, N. \& Teixeira, D. M. (2001). Os viajantes e a biogeografia: História, Ciências, SaúdeManguinhos, vol. VIII (suplemento), 1015-1037. 


\section{AGRADECIMENTOS}

Agradeço à minha família pelo apoio e ensinamentos ao longo da vida.

Agradeço ao meu orientador Dr. Jader Marinho-Filho e ao meu coorientador Dr. Fernando Pacheco Rodrigues pela orientação, oportunidade de trabalhar em conjunto e pela confiança depositada em mim.

Aos colegas e amigos pela colaboração no primeiro capítulo da tese, Ana Carolina Loss, Emerson Monteiro Vieira e Anderson Paz.

Aos colegas e amigos do Laboratório e Coleção de Mamíferos da UnB e do Laboratótio de Genética e Biodiversidade agradeço pelo auxílio em laboratório e conversas sobre biogeografia, evolução e ecologia dos animais encontrados no Cerrado e biomas vizinhos.

Agradeço aos colegas e amigos que auxiliaram nas coletas de campo: Renato Rosa, Thales Magalhães, Tiago, Nárjara Veras, Lilian e Arthur.

Agradeço à Dra. Alexandra Bezerra, Dra. Ana Paula Carmignotto e Dra. Leonora Costa pela doação de tecidos de espécimes estudadas na presente tese.

Aos amigos e colegas Dr. Fabrícius Domingos e Dr. Yuri Luiz Reis Leite pelas valiosas sugestões e conselhos sobre análises e comentários sobre o trabalho.

Ao Programa de Pós Graduação em Zoologia da Universidade de Brasília pelo apoio. À Coordenação de Aperfeiçoamento de Pessoal de Nível Superior pela bolsa de doutorado e ao Instituto Chico Mendes de Conservação da Biodiversidade ICMBio, pela autorização de captura e coleta de espécimes.

Por fim, agradeço a todas as pessoas que de alguma forma contribuíram para que eu atingisse mais um objetivo na minha vida. 


\section{SUMÁRIO}

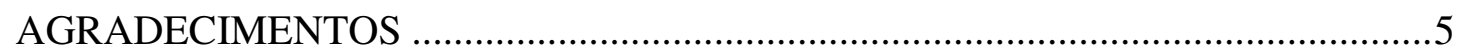

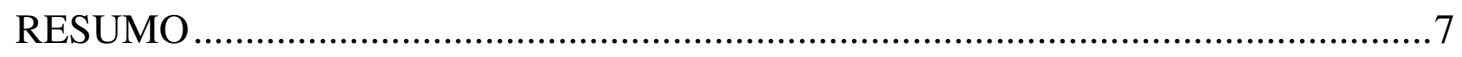

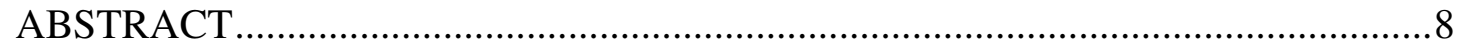

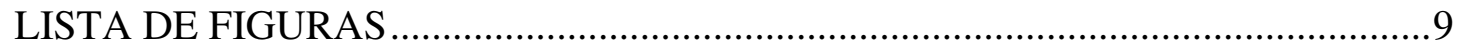

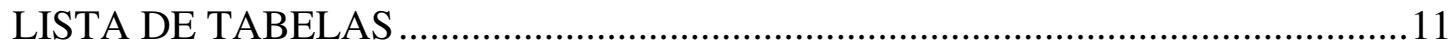

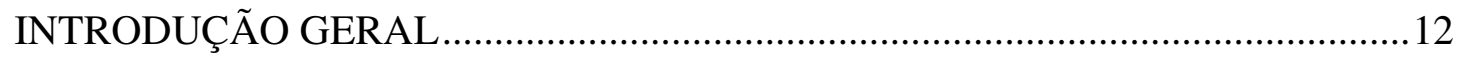

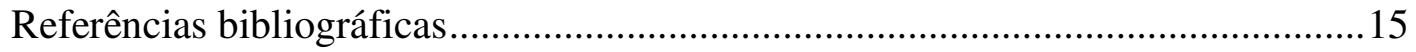

Capítulo 1: A new species of tree rat (Phyllomys, Echimyidae) from Brazilian Cerrado supports Miocene connection between Amazon and Atlantic forests .........................17

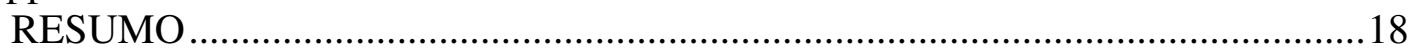

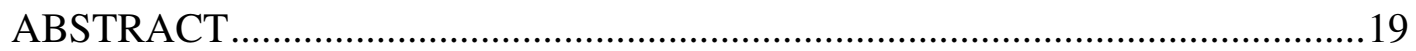

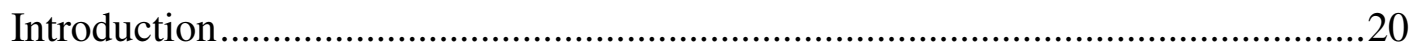

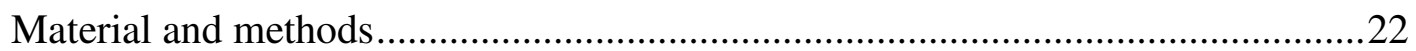

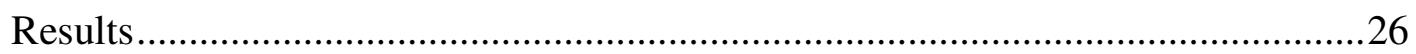

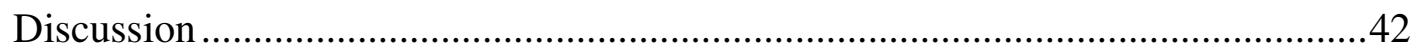

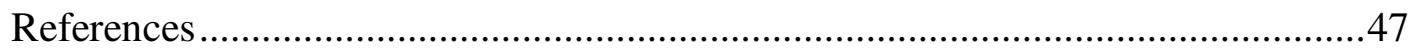

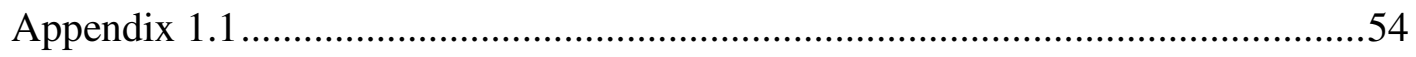

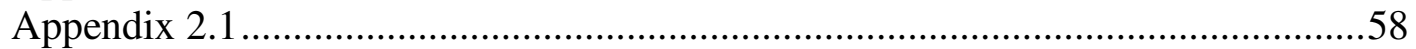

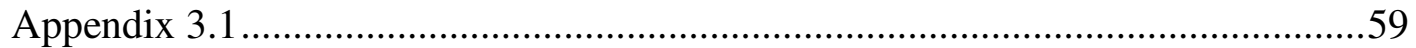

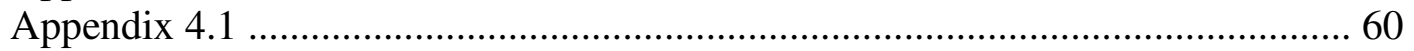

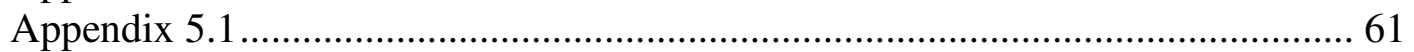

Capítulo 2: Filogeografia e delimitação de espécies em Gracilinanus agilis

(Didelphimorphia, Didelphidae) nos biomas Cerrado e Caatinga ................................72

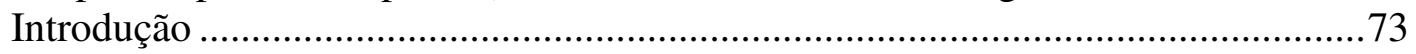

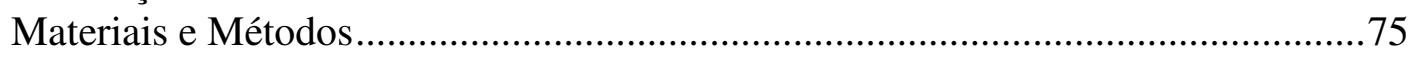

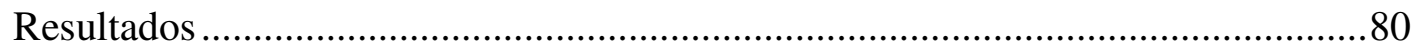

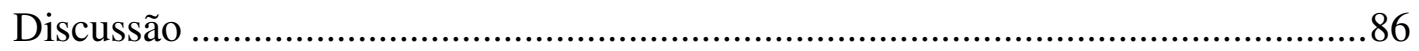

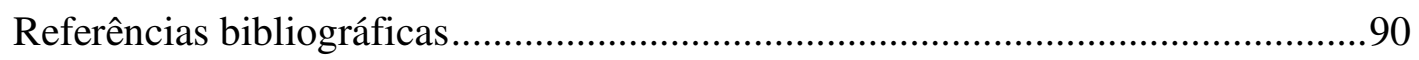

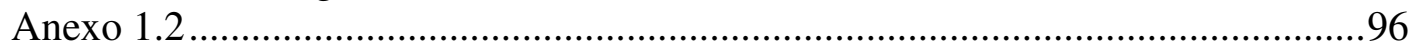

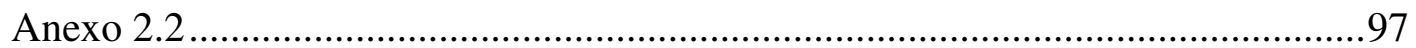

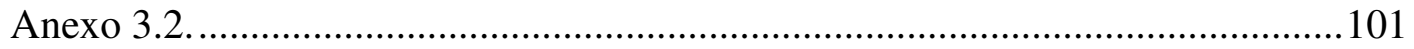

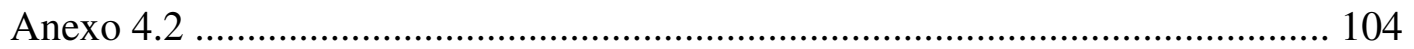

Capítulo 3: Expansão demográfica de Calomys tener (Rodentia, Cricetidae) durante o Quaternário tardio no Cerrado: respostas ao efeito do fogo e ocupação humana pré-

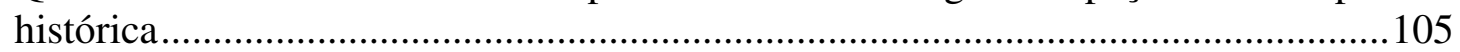

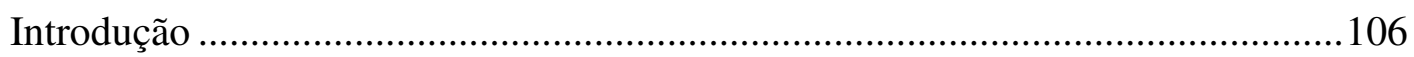

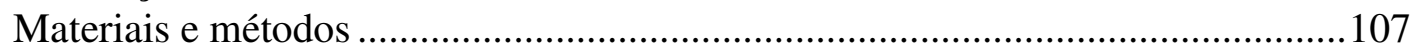

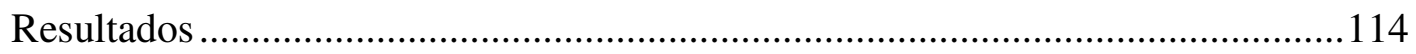

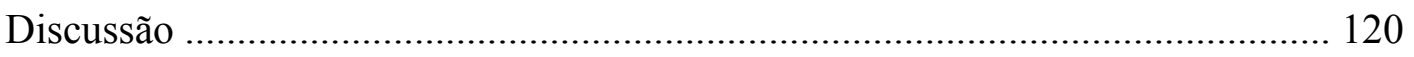

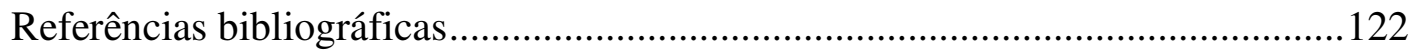

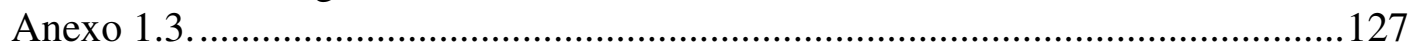

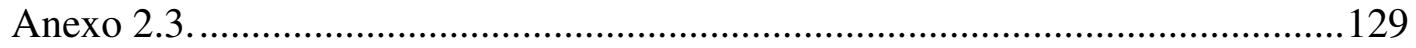

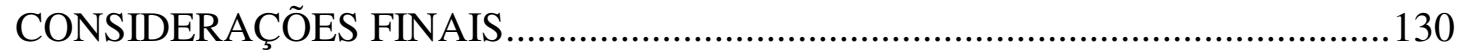




\section{RESUMO}

Os domínios morfoclimáticos da Caatinga e do Cerrado possuem características únicas tanto em termos climáticos, quanto físicos e biológicos. Apresentam ambientes e fitofisionomias particulares que sofreram alterações históricas em seus limites de distribuição geográfica em consequência de mudanças climáticas, eventos geológicos e até mesmo devido a ocupação humana e efeitos de queimadas. Apesar deste passado dinâmico, a história evolutiva e a diversificação dos organismos com distribuição nestes ambientes são pouco exploradas em estudos modernos que utilizam sequências de DNA e métodos biogeográficos, filogeográficos e de demografia histórica. Esta condição é ainda mais evidente em relação aos roedores e marsupiais de pequeno porte, que apesar de serem os grupos de mamíferos com maior diversidade de espécies da América do Sul, são pouco representados em investigações sobre suas diversificações e relações históricas com o Cerrado e a Caatinga. É neste contexto que a presente tese procura contribuir. Foram utilizadas sequências de DNA e métodos filogenéticos e filogeográficos para investigar a relação entre a diversificação de espécies de pequenos mamíferos com a evolução de seus habitats inseridos em fitofisionomias do Cerrado e Caatinga. O primeiro capítulo explora hipóteses filogenéticas e biogeográficas no gênero Phyllomys e contém a descrição de uma nova espécie com distribuição em matas de galerias do Cerrado e áreas de transição com a Floresta Atlântica. Além disso, com base em análise de distribuição ancestral de Phyllomys e outros gêneros distribuídos na Amazônia, é proposta uma hipótese de que habitats apropriados para a ocorrência de ratos de espinho arborícolas se estendiam na atual região sul e central do Cerrado promovendo uma conexão entre Amazônia e Floresta Atlântica durante o Mioceno. O segundo capítulo investiga as relações filogeográficas entre populações de Gracilianus agilis da Caatinga e Cerrado. Propõe que as alterações demográficas sofridas por esta espécie tem relação com a evolução das Matas Secas da região e que G. agilis pode abrigar mais de uma espécie. Por último, o terceiro capítulo avalia se houve alterações demográficas ao longo do tempo em populações de Calomys tener e propõe que eventos de fogo e a ocupação humana na região do Cerrado são fatores que alteram a paisagem natural, criando habitats que possibilitaram o crescimento populacional desta espécie. 


\begin{abstract}
The morphoclimatic domains of Cerrado and Caatinga are unique in terms of biotic, climatic, and geological features. The phytophysiognomies of Cerrado and Caatinga suffered multiple changes in theirs geographic distribution during the last millions years as a consequence of climatic and geologic modifications, fire in natural environments, and pre-historic human settlements. However, the diversification and historical evolution of organisms distributed in these regions are poorly studied. This is much more clearly if one tries to find Cerrado and Caatinga biogeographical studies based in small mammals (rodents and marsupials) as models, and using modern phylogenetic and phylogeographic methods. In this thesis, I used DNA sequences and phylogenetic and phylogeographic methods to investigate small mammals evolution and theirs relationship with the Cerrado and Caatinga phytofisiognomies. The first chapter propose phylogenetic and biogeographic hypothesis for the genus Phyllomys. It contains a description of a new species of Phyllomys and a hypothesis of past link between Amazon and Atlantic forest of South America through where the central/southern Cerrado biome is today. The second chapter investigates phylogeographical relationships of Gracilinanus agilis populations distributed in the Cerrado and Caatinga. I propose that historical expansions and retractions of dry forests of Cerrado and Caatinga are drivers for the diversification of this species, and that populations under G. agilis may represent more than one species. The third chapter focus on historical demographic changes in populations of Calomys tener. The results indicates that burning in natural areas, as well as the pre-historic human settlements may have favored the population expansion of Calomys tener during the late Quaternary.
\end{abstract}




\section{LISTA DE FIGURAS}

Figure 1.1: Bayesian inference phylogram 1 based on concatenated $(v W F, G H R$, $R A G 1, C O I$, and $C y t b)$ molecular data set. Numbers near nodes represent Bayesian posterior probabilities.

Figure 2.1: Live holotype of Phyllomys centralis sp. n. (UNB 3820) after been captured in a live trap installed in a canopy of gallery forest located in the southern portion of APA Gama Cabeça-de-Veado - Federal District, central Brazil. Foto: André Mendonça.

Figure 3.1: Dorsal and ventral views of skins of specimens of Phyllomys centralis sp.

n. The holotype (UNB 3820 - above), and two paratypes (MCN-M 2709 - center; MCN-M 2027 - below). Scale bar $=11 \mathrm{~cm}$

Figure 4.1: Dorsal, ventral, and lateral views of skull and lateral view of mandible of holotype of Phyllomys centralis sp. $\mathrm{n}$. - UNB 3820. (scale bar $=1 \mathrm{~cm})$.

Figure 5.1: Right mandibular (left) and maxillary toothrows of Phyllomys centralis sp. n. (paratype MCN-M2709).

Figure 6.1: Post cranium axial skeleton of Phyllomys centralis sp. n. A - atlas: dorsal tubercle (dt) and ventral tubercle (vt); B - axis: spinous process (sp); C cervical vertebrae: lamina ventralis (lv) of the sixth cervical vertebra; $\mathrm{E}$ - neural process (np) of second thoraxic vertebra; D - the eleventh thoracic vertebra (tv11), and the seventh lumbar vertebra (lv7); F - second sacral vertebra (sv2), ischium (isch), and iliac crest (ic); G - first caudal vertebra (cv1), neural process (np).

Figure 7.1: Sternum region and appendicular skeleton of Phyllomys centralis sp. n. A - sternum region: sternebrae (ste), manubrium (man), and xiphisternum (xiphi); B - scapula: infraspinous fossa (if), supraspinal fossa (sf); C - humerus: deltoid tuberosity (dt); D - radio and ulna: olecranon process (op), and trochlear notch (tn); E - femur: greater trochanter (gt), head of femur (hf), and lesser trochanter (lt); $\mathrm{F}$ - tibia and fibula; $\mathrm{G}$ - manus; $\mathrm{H}$ - pes.

Figure 8.1: Molecular dating chronogram of Phyllomys inferred from concatenated genes ( $v W F, G H R, R A G 1$, and $C y t b)$. Horizontal bars represent $95 \%$ credibility intervals for time estimates.

Figure 9.1: Map of South America showing the limits of the Cerrado, Amazon, and Atlantic Forest biomes. The Atlantic Forest is depicted in sub-regions (see Material and methods for detail). The red polygon refer to the geographic distribution of Phyllomys blainvilii, which is distributed in the relict of Atlantic Forest (Brejos). White star and circles represent collection localities of specimens of Phyllomys centralis sp. n. used in molecular analyses. White star represent the type locality (Brasília, Federal District - Brazil) of Phyllomys centralis sp. $\mathrm{n}$. The chronogram is the result of molecular dating analysis inferred from concatenated genes ( $v W F, G H R, R A G 1$, and $C y t b)$. Colored circles near terminal names refers to geographical distribution of each taxon accordingly to associated biomes. Pie chart shows approximate probabilities of ancestral area distribution (only areas with probabilities higher than $30 \%$ are shown). Geological time limits are based in Gibbard et al. (2010).

Figura 1.2: A) Grupos genéticos indicados pela análise no programa BAPS; B) Filograma resultante da análise filogenética com base em sequências do cyt-b realizada no programa MrBayes. Nós com círculo preto apresentam 
probabilidade posterior $>0,95$; C) Mapa mostrando Cerrado em bege, Caatinga em marrom e rio São Francisco em cinza. Cores das barras em figura A e dos terminais da filogenia em B indicam correspondência com as localidades de mesma coloração da figura $\mathrm{C}$.

Figura 2.2: A) Filogenias de genes nucleares, da esquerda para direita: OGT, P4HB e PPIC. Nós com círculo em preto significam probabilidade superior $>0,95 ; \mathrm{B}$ ) Filogenia de espécies (cytb e PPIC): terminais A, B e C são populações derivadas das localidades correspondentes na figura C. C) mapa indicando localidades de origem das sequências analisadas nas árvores de gene e de espécie. Caatinga em marrom e Cerrado em bege...............................................83

Figura 3.2: Tamanho efetivo populacional através do tempo das populações A (esquerda), B (centro), C (direita) de G. agilis com base em Bayesian Skyline Plots. Área em azul representa intervalo de 95\% de HPD.

Figura 1.3: Mapa destacando a região do Cerrado e pontos de coleta de espécimes de Calomys tener utilizados nas análises. 109

Figura 2.3: Modelos demográficos históricos de populações de $C$. tener testados no programa DIYABC. 1) população grande sem alteração demográfica ao longo do tempo; 2) população pequena sem alteração demográfica; 3) expansão demográfica no começo do Holoceno coincidindo com ocupação humana e registro de fogo no Cerrado - clima seco; 4) expansão demográfica há 32.000 anos atrás devido a existência de um Cerrado antigo frequentemente atingido por fogo - clima seco; 5) expansão demográfica a partir do último máximo interglacial, modelo alternativo - clima quente e úmido. $\mathrm{Ne}=$ tamanho da população efetiva. Tempo fora de escala....... 113

Figura 3.3: Redes de haplótipos com base nos marcadores ADH (A), Bfib (B) e cyt-b (C). Cada círculo representa um haplótipo. Quanto maior o tamanho do círculo maior o número de amostras apresentando o mesmo haplótipo. Cores representam localidades de coleta de acordo com a legenda a direita. Traços nos braços que ligam haplótipos representam números de mutações 115

Figura 4.3: Filogenias resultantes da análise bayesianas com base em sequências do cyt-b (A), ADH (B) e Bfib (C). Retângulos indicam exemplares de Calomys tener (grupo interno). Probabilidade posterior (pp) para o monofiletismo de $C$. tener: $\mathrm{pp}=1$ para cyt-b e $\mathrm{ADH}$ e $\mathrm{pp}=0.67 \mathrm{Bfib}$. 116

Figura 5.3: Tamanho efetivo populacional através do tempo estimado com sequências do cyt-b de $C$. tener com base em Bayesian Skyline Plots. Área em azul representa intervalo de $95 \%$ de HPD.

Figura 6.3: Árvore de espécies utilizando sequências de todos os marcadores (cyt-b, ADH e Bfib) e datação molecular. Número próximo ao nó significa probabilidade posterior. Probabilidade abaixo de 0,9 não apresentada. 118

Figura 7.3: Plots do algoritmo de regressão logística para cada cenário demográfico estimado no programa DIYABC. Modelos 3 e 4 com maiores valores de probabilidade posterior. 


\section{LISTA DE TABELAS}

Table 1.1: Cranial measurements of Phyllomys centralis sp. n. (UNB 3820, MCNM2709, and MCN-M2153), Phyllomys blainvilii, and Phyllomys brasiliensis. Measurements taken from Phyllomys blainvilii, and Phyllomys brasiliensis were taken from Leite (2003).

Table 2.1: Table showing selected characters used to delimit $P$. centralis $\mathrm{sp} . \mathrm{n}$. in relation to the sister species ( $P$. mantiqueirensis) and species with similar geographic distribution: $P$. blainvilii and $P$. brasiliensis.

Tabela 1.2: Resultados obtidos nos testes de desvios do modelo neutro de evolução para as diferentes populações encontradas. Indicadores estatísticos utilizados: $D$ Tajima, $F s$ Fu e $R_{2}$ Ramos-Onsins and Rozas .84

Tabela 1.3: Valores das estatísticas $D$ de Tagima, $F s$ de Fu e $R_{2}$ de Ramos-Onsins e Rozas, que testam desvios do modelo neutro de evolução. Asterisco indica probabilidade $<0,05$ 


\section{INTRODUÇÃO GERAL}

O corredor de formações abertas da América do Sul forma uma diagonal de ambiente secos composta pela Caatinga no nordeste do Brasil, Cerrado no Brasil central e Chaco, que ocupa porções da Argentina, Paraguai e Bolívia (Werneck, 2011). Em especial, o Cerrado e a Caatinga possuem características climáticas, geológicas e biológicas únicas (Ab’Sáber, 2000) e isolam as duas maiores regiões de florestas úmidas da América do Sul, Amazônia e Floresta Atlântica. A Caatinga é formada em grande parte por florestas decíduas (matas secas) e considerada como maior remanescente de uma vegetação estabelecida de maneira relictual na América do Sul, América Central e sul da América do Norte (Prado \& Gibbs, 1993). O Cerrado, por sua vez, é caracterizado por um gradiente horizontal de fitofisionomias e basicamente composto por savanas, campos, matas secas e florestas de galerias (Ratter et al. 1997; Ribeiro \& Walter 2008). Em especial, as florestas de galerias do Cerrado compartilham componentes vegetais com a Amazônia no norte/nordeste e com Floresta Atlântica no sul/sudeste (Oliveira-Filho \& Ratter 1995) formando corredores de vegetação mais úmida ocupados por organismos autóctones e derivados dos biomas vizinhos. Além disso, são propostas conexões históricas entre florestas da Amazônia e Floresta Atlântica em regiões em que hoje em dia o Cerrado e a Caatinga estão estabelecidos (Oliveira-Filho \& Ratter 1995). Eventos de contato e isolamento entre estas florestas estariam relacionados com o histórico de retrações e expansões ao longo do tempo das fitofisionomias do Cerrado e da Caatinga que ocorreram em função de mudanças climáticas e geológicas (Andrade-Lima, 1982; Auler et al. 2004; Bigarella et al. 1975; Rizzini, 1963; Werneck et al. 2011). Esta dinâmica histórica estabelece um complexo cenário evolutivo para a biota destas regiões pouco explorado em estudos biogeográficos (Werneck, 2011).

Informações provenientes de sequências de DNA representam dados robustos para estudos biogeográficos. A filogeografia é uma disciplina que faz uso deste conjunto de dados e permite inferir processos evolutivos intraespecíficos e analisar a estruturação geográfica com base em genealogias (Avise et al. 1987). Uma derivação desta disciplina, a demografia histórica, permite testar cenários de contato entre populações, expansão e retração demográfica ao longo do tempo fornecendo indícios da ocorrência de seleção natural, deriva e gargalos genéticos numa perspectiva geográfica (Avise, 2009; Hickerson et al. 2010). Além disso, sequências de DNA viabilizam estudos de biogeografia histórica (Yu et al. 2010; Yu et al. 2015) e datação 
molecular (Drummond et al. 2006), permitindo compreender quais seriam as áreas de distribuição dos ancestrais de táxons viventes e em que épocas ocorreram os eventos de diversificação, dispersão e extinção que foram determinantes para a configuração do cenário biogeográfico atual. A aplicação de tais métodos com base em sequências de DNA pode contribuir decisivamente para o entendimento da história biogeográfica das formações abertas da diagonal seca, bem como permitir o teste de hipóteses propostas em estudos pioneiros na região (e.g. Werneck et al. 2011).

Pequenos mamíferos das ordens Didelphimorphia e Rodentia representam os grupos com maior diversidade de espécies da América do Sul (Gardner \& Creighton, 2007; Lessa et al. 2014, Patton et al. 2015) e com grande número de gêneros e espécies endêmicas da Caatinga e Cerrado (Carmignotto et al. 2012). Pequenos roedores e marsupiais tem servido de modelos de estudo para investigações biogeográficas em escalas regional (Giarla et al. 2014), continental (Leite et al. 2014) e global (Schenk et al. 2013). Contudo, hipóteses filogeográficas e de demografia histórica no Cerrado e Caatinga utilizando estes grupos como modelos são escassas, podendo ser enumeradas algumas poucas pesquisas com Calomys (Almeida et al. 2007; Nascimento et al. 2011), Trichomys (Nascimento et al. 2013) e Gracilinanus agilis (Faria et al. 2013). Neste contexto, estudos que relacionem a dinâmica evolutiva do Cerrado e Caatinga com evidências de estruturação genética e diversificação de pequenos mamíferos é uma demanda evidente e um campo pouco investigado nas formações vegetais da diagonal de ambientes secos.

O objetivo da presente tese foi investigar a diversificação de pequenos mamíferos no Cerrado, Caatinga e florestas de galeria do Cerrado e suas conexões com Amazônia e Floresta Atlântica. Para isso utilizou-se dados de sequências de DNA e métodos filogeográficos, demografia histórica, datação molecular e biogeografia histórica tendo como grupos de estudo as espécies Calomys tener (Rodentia, Cricetidae), Gracilinanus agilis (Didelphimorphia, Didelphidae) e o gênero Phyllomys (Rodentia, Echimyidae). A obtenção de amostras foi conduzida através de coletas em campo em diversas localidades inseridas no Cerrado e adjacências deste bioma, precisamente nas seguintes localidades: Parque Nacional (PARNA) de Emas - GO; PARNA da Chapada dos Guimarães - MT; PARNA Serra da Canastra - MG; PARNA Grande Sertão Veredas - BA, MG; PARNA do Araguaia - TO; PARNA Chapada das Mesas - MA; Parque Estadual Serra de Ricardo Franco MT; e região do rio das Mortes, nas proximidades do município de Nova Xavantina - 
MT. Adicionalmente, por meio de doações de colegas e coleções científicas, foram obtidas amostras de tecidos de animais de diversas outras localidades compreendendo um conjunto de dados totalmente original e representativo em relação ao conhecimento da distribuição geográfica dos organismos estudados.

A tese está estruturada em três capítulos. O primeiro trata da biogeografia histórica do gênero Phyllomys e descreve uma espécie nova para a região do Cerrado e áreas de transição com a Floresta Atlântica. O segundo capítulo investiga as relações entre estruturação geográfica de populações de G. agilis do Cerrado e Caatinga e a dinâmica histórica de expansões e retrações das Matas Secas, principal habitat desta espécie. Por último, o terceiro capítulo avalia se houve alterações demográficas ao longo do tempo em populações de $C$. tener no Cerrado, e se tais alterações tem relação com a incidência de fogo em seu habitat. 


\section{Referências bibliográficas}

Ab'Sáber, A. N. (2000). The natural organization of Brazilian inter-and subtropical landscapes. Revista Do Instituto Geológico, 21, 57-70.

Andrade-Lima, D. de. (1982). Present-day forest refuges in northeastern Brazil. In G. T. Prance (Ed.), Biological diversification in the Tropics (pp. 245-251). New Yourk: Columbia University Press.

Auler, A. S., Wang, X., Edwards, R. L., Cheng, H., Cristalli, P. S., Smart, P. L., \& Richards, D. A. (2004). Quarternary ecological and geomorphic changes associated with rainfall events in presently semi-arid northeastern Brazil. Journal of Quaternary Science, 19, 693-701.

Avise, J. C. (2009). Phylogeography: retrospect and prospect. Journal of Biogeography, 36, 3-15.

Avise, J. C., Arnold, J., Ball, R. M., Bermingham, E., Lamb, T., Neigel, J. E., ... Saunders, N. C. (1987). Intraspecific Phylogeography: The Mitochondrial DNA Bridge Between Population Genetics and Systematics. Annual Review of Ecology and Systematics, 18, 489-522.

Bigarella, J. J., Andrade-Lima, D. de, \& Riehs, P. J. (1975). Considerações a respeito das mudanças paleoambientais na distribuição de algumas espécies vegetais e animais no Brasil. In J. J. Bigarella \& R. D. Becker (Eds.), Simpósio internacional sobre o Quaternário (47th ed., pp. 411-464). Curitiba - Porto Alegre: Anais da Academia Brasileira de Ciências.

Carmignotto, A. P., Vivo, M. De, \& Langguth, A. (2012). Mammals of the Cerrado and Caatinga: distribution patterns of the tropical open biomes of central South America. In B. D. Patterson \& L. P. Costa (Eds.), Bones, clones and biomes. The history and geography of recent Neotropical mammals (pp. 307-350). Chicago, Illinois: University of Chicago Press.

Drummond, A. J., Ho, S. Y. W., Phillips, M. J., \& Rambaut, A. (2006). Relaxed phylogenetics and dating with confidence. PLoS Biology, 4, 699-710.

Faria, M. B., Nascimento, F. F., Oliveira, J. A., \& Bonvicino, C. R. (2013). Biogeographic determinants of genetic diversification in the mouse opossum Gracilinanus agilis (Didelphimorphia: Didelphidae ). Journal of Heredity, 104, 613-626.

Giarla, T. C., Voss, R. S., \& Jansa, S. A. (2014). Molecular Phylogenetics and Evolution Hidden diversity in the Andes: Comparison of species delimitation methods in montane marsupials. Molecular Phylogenetics and Evolution, 70, $137-151$.

Hickerson, M. J., Carstens, B. C., Cavender-Bares, J., Crandall, K. a, Graham, C. H., Johnson, J. B., ... Yoder, a D. (2010). Phylogeography's past, present, and future: 10 years after Avise, 2000. Molecular Phylogenetics and Evolution, 54, 291-301.

Leite, R. N., Kolokotronis, S., Almeida, F. C., Werneck, F. P., Rogers, D. S., \& Weksler, M. (2014). In the wake of invasion: tracing the historical biogeography of the South American cricetid radiation. Plos One, 9, 1-12.

Lessa, E. P., Cook, J. A., D’Elía, G., \& Opazo, J. C. (2014). Rodent diversity in South 
America: transitioning into the genomics era. Frontiers in Ecology and Evolution, 2, 1-7.

Nascimento, F. F., Lazar, A., Menezes, A. N., Durans, M., Moreira, J. C., SalazarBravo, J., ... Bonvicino, C. R. (2013). The role of historical barriers in the diversification processes in open vegetation formations during the Miocene/Pliocene using an ancient rodent lineage as a model. Plos One, 8, 1-13.

Oliveira-Filho, A. T., \& Ratter, J. A. (1995). A study of the origin of central brazilian forests by the analysis of plant species distribution patterns. Edinburg Journal of Botany.

Patton, J. L., Pardiñas, U. F. J. \& D'Elía, G. (2015). Mammals of South America, Volume 2: Rodents. University of Chicago Press. Chigago (1384 pages)

Prado, D. E., \& Gibbs, P. E. (1993). Patterns of species distribution in the Dry Seasonal Forest of South America. Annals of the Missouri Botanical Garden, 80, 902-927.

Ratter, J. A., Ribeiro, J. F., \& S., B. (1997). The Brazilian Cerrado Vegetation and Threats to its Biodiversity. Annals of Botany, 80, 223-230.

Rizzini, C. T. (1963). Nota prévia sobre a divisão fitogeográfica do Brasil. Revista Brasileira de Geografia, 1, 3-64.

Schenk, J. J., Rowe, K. C., \& Steppan, S. J. (2013). Ecological opportunity and incumbency in the diversification of repeated continental colonizations by Muroid rodents. Systematic Biology, 62, 837-640.

Werneck, F. P. (2011). The diversification of eastern South American open vegetation biomes: Historical biogeography and perspectives. Quaternary Science Reviews, 30, 1630-1648.

Werneck, F. P., Costa, G. C., Colli, G. R., Prado, D. E., \& Sites Jr, J. W. (2011). Revisiting the historical distribution of Seasonally Dry Tropical Forests: new insights based on palaeodistribution modelling and palynological evidences. Global Ecology and Biogeography, 20, 272-288.

Yu, Y., Harris, A. J., Blair, C., \& He, X. (2015). RASP (Reconstruct Ancestral State in Phylogenies): a tool for historical biogeography. Molecular Phylogenetics and Evolution, 87, 46-49.

Yu, Y., Harris, A. J., \& He, X. (2010). Molecular Phylogenetics and Evolution SDIVA (Statistical Dispersal-Vicariance Analysis): A tool for inferring biogeographic histories. Molecular Phylogenetics and Evolution, 56, 848-850. 
Capítulo 1

A new species of tree rat (Phyllomys, Echimiydae) from Brazilian Cerrado supports Miocene connection between Amazon and Atlantic forests 


\section{RESUMO}

As florestas de galeria localizadas no Cerrado do Brasil central possuem intensa presença de elementos vegetais da Amazônia e da Floresta Atlântica. Diversas hipóteses são propostas sobre conexões históricas entre Amazônia e Floresta Atlântica em locais onde hoje o Cerrado e a Caatinga estão estabelecidos, e que tais conexões seriam determinantes para a diversificação de organismos presentes nestas regiões. Neste estudo foram investigadas as relações filogenéticas do rato de espinho da Floresta Atlântica (Phyllomys, Echimyidae) e feita a descrição de uma nova espécie oriunda de florestas de galerias do Cerrado e áreas de transição entre Cerrado e Floresta Atlântica. Foram realizadas análises de datação molecular e distribuição geográfica dos ancestrais das espécies viventes de Phyllomys e grupos externos (Echimys e Makalata) distribuídos na Amazônia, com o objetivo de gerar hipóteses sobre possíveis rotas de dispersão e locais que poderiam abrigar conexão entre a Floresta Atlântica e a Amazônia. Durante o Mioceno, o ancestral comum mais recente de Phyllomys e Echimys provavelmente ocupava a região em que hoje está situada a porção central/sul do Cerrado, enquanto que a maioria dos eventos de diversificação em Phyllomys ocorreram durante o Plioceno e Pleistoceno. Os resultados indicam uma possível existência de conexão florestal durante o Mioceno entre Amazônia e Floresta Atlânica na região atual central/sul do Cerrado, favorecendo uma hipótese de conexão pretérita nesta região entre as duas formações florestais. A espécie nova de Phyllomys é a única do gênero com distribuição na região core do Cerrado, indicando que houve uma especiação in situ de uma linhagem derivada de divergência antiga na árvore de Phyllomys e implicando em expansões e contrações de florestas durante o período Terciário. 


\begin{abstract}
The gallery forests in the Brazilian Cerrado, a vast tropical savanna in South America and a biodiversity hotspot, are composed by biotic elements derived from the adjacent Amazon (AM) and the Atlantic Forest (AF) biomes. Past connections between AM and AF took place through the region where the dry Cerrado and Caatinga domains occur today. Here we describe and name a new species of Atlantic Forest tree rat, Phyllomys centralis sp. n., from the gallery forests of the Cerrado and transitional areas. We inferred molecular phylogenies, divergence dates, and ancestral ranges of Phyllomys species and their close relatives from the AM, Echimys and Makalata. The most recent common ancestor of Phyllomys and Echimys probably occupied the central/southern region of the Cerrado during the Miocene, while the diversification within Phyllomys species in the AF occurred during the PlioPleistocene. These results favor the hypothesis of a past link between AM and AF where the central/southern Cerrado biome is today. The new species found in the gallery forests of Cerrado indicate in situ speciation of a lineage derived from an ancient divergence and implying that forest expansion and contractions occurred during the Tertiary.
\end{abstract}




\section{Introduction}

The Amazon (AM) and Atlantic Forest (AF) in South America are separated by a "diagonal of open formations" (Ab'Sáber 1977), a corridor of drylands composed by the Argentinean and Paraguayan Chaco, the Caatinga in north-eastern Brazil, and the Cerrado. The Cerrado domain lies over 2,000,000 $\mathrm{km}^{2}$ in central Brazil with, basically, three main vegetation types: savannas, dry forests (both deciduous and semi-deciduous forests), and gallery forests (Ratter et al. 1997; Ribeiro \& Walter 2008). In particular, floristic elements from forested formations of the Cerrado are shared with the AM in the north/west and with AF at east/southern portion of the Cerrado (Oliveira-Filho \& Ratter 1995).

There is evidence indicating biotic similarities between AF and central Brazilian forests that extend over the Cerrado, leading to the hypothesis of a past forest link between AM and AF (Rizzini 1963; Oliveira-Filho \& Ratter 1995). Recent studies reinforced this idea by showing phylogeographic affinities between forest trees from AF and gallery forests of Cerrado (Ramos et al. 2009), bird lineages shared by AF and Cerrado gallery forests (Silva 1997), and sister group relationships among lineages of mammals (Costa 2003) and amphibians (Fouquet et al. 2012) distributed in AM and AF. Time and place where the connections between AM, AF, and Cerrado forests occured are variable, indicating a number of events of expansions and retractions of forested and non-forested environments during the Tertiary and Quaternary (e.g. Oliveira-Filho \& Ratter 1995; Auler et al. 2004). Basically, there are three main hypothetic routes that likely played a role in the dynamics of contacts between AF and AM: the northeastern route (Bigarella et al. 1975; Andrade-Lima 1982; Auler et al. 2004; Wang et al. 2004) where the semi-arid Caatinga is nowadays the dominant ecosystem; the central route which could have run through central Brazil, either as a continuous forest corridor or as a series of forest patches (Por 1992; Oliveira-Filho \& Ratter 1995; Costa 2003); and the southern route (Por 1992; Costa 2003; Batalha-Filho et al. 2013), where organisms from AF could have reached Amazonian formations through the Paraná hydrographic basin (Por 1992).

A clear case of sister lineages with disjunct distributions in the $\mathrm{AM}$ and $\mathrm{AF}$ occurs within the tree-dwelling sister genera Echimys and Phyllomys, members of the family Echimyidae of spiny rats. Species of Echimys are mainly distributed in AM forest and Phyllomys species are found in the AF (Leite \& Patton 2002; Galewski et al. 2005; Upham et al. 2013) domain. After diverging from the common ancestor 
shared with Echimys, the lineage leading to Phyllomys experimented an impressive diversification and, currently, species of Phyllomys are found in almost the entire range of the AF (Leite 2003), although there are no hypotheses regarding probable routes or geographic directions to the diversification of this genus. Systematics and taxonomy of Phyllomys is still very confuse, and only in the beginning of the $21^{\text {th }}$ century species names attributed to morphotypes became more clearly recognized (Emmons et al. 2002). Thirteen nominal species of Phyllomys are recognized: $P$. mantiqueirensis, P. medius, $P$. nigrispinus, P. pattoni, P. thomasi, P. unicolor, $P$. blainvilii, P. brasiliensis, $P$. dasythrix, P. kerri, P. lamarum, P. lundi, and P. sulinus (Leite 2003; Leite et al. 2008). The great morphological similarities shared by them is seemingly resulted from a rapid event of diversification of the genus (Leite, 2003), and the recognition of some of these species is somewhat possibly based on karyotype information and molecular phylogenetics. More recently, phylogenetic analyses of nuclear and mitochondrial DNA detected other four monophyletic lineages of Phyllomys, representing species awaiting for formal description (Loss \& Leite 2011; Araújo et al. 2014).

Recent small mammal collections in central Brazil revealed an unexpected record of an exemplar of Phyllomys in a gallery forest in the core area of the Cerrado biome. Evidences based in morphological and molecular genetics indicate this specimen as conspecific to Phyllomys specimens founded in transitional areas between Cerrado and AF, and identified as the fourth undiscribed Phyllomys species by Araújo et al. (2013). We named and describe this new species in this present paper, and perform ancestral reographical range analyses of Phyllomys and related taxa from AM in order to explore hypotheses on the dynamic contact of forests within the Cerrado, AF, and AM. To verify the best-fit hypothesis among the three available alternative hypotheses regarding the routes and connections between the Cerrado forests, AM, and AF, we predict that if the ancestral range of the most recent common ancestor of Phyllomys and Echimys is estimated to be located at northeastern AF, then the northeastern contact route is likely to have played a role in the diversification of these genera. Otherwise, if the ancestral range of the most recent common ancestor of Phyllomys and Echimys is estimated to have occured in the central or southern AF, then the two alternative contact routes (central and southern) are more likely to have played a role in the diversification of these genera. 


\section{Material and methods}

\section{Taxonomic sampling and morphological description}

To investigate the phylogenetic relationship of the Phyllomys specimens, we used DNA sequences from the specimen collected in the Cerrado biome along with other 25 specimens as terminal taxa distributed in 13 recognized Phyllomys species (sensu Loss \& Leite 2011; Araújo et al. 2014): P. blainvilii, P. brasiliensis, P. dasythrix, P. lamarum, P. lundi, P. mantiqueirensis, P. nigrispinus, P. pattoni, $P$. sulinus, Phyllomys sp. 1, Phyllomys sp. 2, Phyllomys sp. 3, and Phyllomys sp. 4. The Echimyidae species, Echimys chrysurus and Makalata didelphoides were used as outgroups, given the closest relationship o these species and Phyllomys, tipically retrived as sister clades in previous studies (Loss \& Leite 2011; Upham et al. 2013; Upham \& Patterson 2015). Other four valid species of Phyllomys were not included in the present study (as any other molecular phylogenetic study) given the inexistence of DNA samples: P. medius, P. kerri, P. thomasi, and P.unicolor. However, the combination of morphological information and known geographic distribution of these four species suggest non-synonymies regarding to all other species of Phyllomys considered in our analyses (Leite, pers. comm.).

For the molecular clock analyses we included other clades of the Infraorder Hystricognathi, in order to accept multiple calibration points and composed by the Echimyidae Dactylomys boliviensis, Mesomys hispidus, Isothrix bistriata, Thrichomys apereoides, Proechimys cuvieri, Myocastor coypus, Callistomys pictus, Trinomys iheringi, Euryzygomatomys spinosus, Clyomys laticeps; the Octodontidae Octodondomys gliroides; the Ctenomyidae Ctenomys coyhaiquensis; the Abrocomidae; Abrocoma bennettii; and the Chinchillidae Chinchilla lanigera. For a complete list of specimens analyzed and museum catalog number see appendix 1.1.

For the morphological description of the new species we use the terminology of Argot (2004) and Carrizo \& Díaz (2013) for post-cranial anatomy; for external and cranial morphology we follow Emmons et al. (2002) and Leite (2003); the dental nomenclature according to Iack-Ximenes et al. (2005). Morphological comparisons were made between Phyllomys sp. n. (specimens UNB3820, MCN-M2709, MCNM2153), $P$. brasiliensis (specimens MCN-M1733, MCN-M1734), literature information for P. blainvilii (Leite, 2003) given the close geographic range of these species, and literature information (Leite, 2003) of the sister species $P$. mantiqueirensis. 
Twenty-three cranial measurements were taken with a digital caliper to the nearest $0.01 \mathrm{~mm}$. These are the same used by Leite (2003): greatest skull length (GSL), nasal length (NL), rostral length (RL), orbital length (OL), rostral breadth (RB), interorbital constriction (IOC), mastoid breadth (MB), zygomatic breadth (ZB), condyloincisive length (CIL), basilar length (BaL), diastema length (D), maxillary toothrow length (MTRL), total palatal length (PLa), posterior palatal length (PLb), incisive foramina length (IFL), bullar length (BuL), postpalatal length (PPL), mesopterygoid fossa width (MPF), maxillary breadth (MaxB), occipital condyle width (OccW), rostral depth (RD), cranial depth (CD), and cranial depth at M1 (CDM1). External measurements were obtained from skin tags or field notes: total length (TOL), tail length (TAL), hind-foot length (HF), and ear length (E).

\section{Molecular data, phylogenetic reconstructions and dating}

DNA extractions from tissue samples preserved in ethanol were made following Bruford et al. (1992). Five DNA fragments were used for the molecular phylogenetic reconstructions: the two mitochondrial genes cytochrome- $b$ (cytb) and cytochrome- $c$ oxidase I (COI); and three nuclear genes, the exon 28 of the nuclear von Willebrand factor $(v W F)$, the exon 10 of the growth hormone receptor $(G H R)$, and the recombination activating gene $1(R A G l)$. Primers used in the amplification process were the MVZ05 and MVZ16 (Smith \& Patton 1993) for the cytb; LCO and HCO (with a tail M13: LepF1_t1, VF1d_t1, LepR1_t1 e VR1d_t1) (Ivanova et al. 2007) for COI; V10 and W13 (Galewski et al. 2005), V2 and W1 (Huchon et al. 1999) for $v W F$; GHREND and GHR50F (Adkins et al. 2001), GHR10F, GHR11F e GHR14R (Upham et al. 2013) for GHR; RAG1F1705 and RAG1R2864 (Teeling et al. 2000), FMNH2b and FMNH3a (Patterson \& Velazco 2008) for RAG1.

Concentration and volume of reagents used for each polymerase chain reaction (PCR) were variable for each species and can be obtained under request to the authors. Thermocycling conditions for the amplification process of each marker can be found at appendix 2.1 .

PCR products were purified using ExoSAP enzymes (GE Healthcare Life Sciences). The cycle-sequencing reactions were performed using BigDye Terminator 3.1 (Applied Biosystems, Inc.) and same primers used for PCR. Samples were sequenced in both directions using the automated DNA sequencer ABI 3500 (Applied Biosystems Inc.) following manufacturer's protocol for sequencing reaction. 
Sequences were aligned in Geneious 6.1 (Biomatters, Auckland, New Zealand). Appropriate models of evolution for each gene partition were determined in jModelTest 2.1.7 (Darriba et al. 2012), allowing for three substitutions schemes and gamma parameter estimate using Bayesian Information Criterion (see appendix 3.1 for selected evolutionary model for each partition). All obtained sequences were deposited in GenBank. Accession numbers of the sequences obtained here and additional sequences downloaded from GenBank are available in appendix 1.1.

We used Bayesian Inference (BI) implemented in MrBayes v.3.0b4 (Huelsenbeck \& Ronquist 2001) to reconstruct phylogenetic relationships within Phyllomys species. This analysis was performed using a concatenated data set of all molecular markers (cytb, COI, vWF, GHR, RAG1) from 26 Phyllomys specimens and two outrgroups (Makalata didelphoides and Echimys chrysurus) totaling 3,996 base pairs (bp) for each terminal taxa. The dataset was partitioned by gene allowing each partition to evolve under an independent model. We used two chains of Markov chain Monte Carlo (MCMC) in MrBayes running for 100 millions generations, sampling one tree every 500 generations, and resulting in 200.000 trees. We discarded the first $25 \%$ samples as burn-in and estimated a 50\% majority-rule consensus from the remaining trees.

In order to calibrate the molecular clock, we included sequences from other Caviomorpha taxa (appendix 1.1). Since there are no COI sequences available for most of the outgroups used in this analysis we excluded this marker for the divergence time estimative, resulting in a data matrix with 44 terminal taxa and 3,330 bp (cytb, vWF, GHR, RAG1) for each taxa.

We estimated the time to most recent common ancestor (with SD and 95\% credibility interval) among Phyllomys lineages using relaxed clock with Log normal distribution and Yule prior as implemented in BEAST 2.3.2 (Drummond et al. 2012) with unlinked evolutionary models and clock rates between partitions. We used a constraint topology by forcing the monophyly of groups according to our previous analysis with all molecular markers for Phyllomys species and following Upham and Patterson (2015), Upham et al. (2013) and Loss et al. (2014) for other Caviomorpha phylogenetic relationships. The software TRACER v1.3 (Rambaut \& Drummond 2007) was used for check convergence in the log likelihood of retrieved trees.

Relaxed clock analysis performed in the BEAST software was used to date the phylogenetic tree. We used three fossils to calibrate the molecular clock following 
Upham et al. (2013) and Upham and Patterson (2015). All calibration points were set as minimum dates (offset) with lognormal priors, mean $=0$ and standard deviation $(\mathrm{SD})=1$. First calibration point represents the most recent common ancestor (MRCA) of Chinchilloidea/Octodontoidea. The minimum age was constrained at 29.5 million years ago using the oldest stem octodontoid, Draconomys verai from the early Oligocene Sarmiento Formation at Gran Barranca, Argentina, pre-Deseadan SALMA - South American Land Mammal Age (Vucetich et al. 2010; Antonie et al. 2012). Second calibration point represents MRCA of Octodontidae/Ctenomyidae. The minimum age was constrained at $5.7 \mathrm{Ma}$ using the stem ancestor of Ctenomys, Xenodontomys simpsoni from the late Miocene Los Salitres Formation at Laguna Chasicó, Argentina, late Huayquerian SALMA (Verzi 2008; Verzi et al. 2013). Third calibration point represents MRCA of the Thrichomys-Callistomys-MyocastorProechimys clade. The minimum age was constrained at 6.0 Ma using the stem ancestor of the Thrichomys lineage, Pampamys emmonsae from the late Miocene Cerro Azul Formation at Laguna Chillhué, Argentina, Chasicoan-Huayquerian SALMA (Verzi et al. 1995, 2013; Olivares \& Verzi 2014).

The Markov chains ran for $10^{7}$ generations sampling 1 tree every $10^{3}$ generations, which resulted in $10^{4}$ trees. Tracer v1.6 (Rambaut et al. 2014) was used to visualize BEAST output files and check for convergence. This analysis indicated effective sample size values all higher than 200.

\section{Biogeographic analyses}

We constructed a map (Appendix 4.1) showing occurrence localities of Phyllomys species based in a series of records obtained in museum collections. A complete list of specimens used to contruct the map and details are provided in Appendix 5.1).

The ancestral geographical distribution of Phyllomys species were inferred using the Bayesian approach - Bayesian Binary MCMC (BBM) Method For Ancestral State in the software RASP 3.1 (Reconstruct Ancestral State in Phylogenies; Yu et al. 2015). Using this approach we can track what region of AF played a role in the contact with AM and forest areas of Cerrado during the diversification of Phyllomys and related outgroups. For this analysis the tree chronogram resulting from the dating analyses of BEAST software was used as input. We pruned the tree terminals so each species were represented by one sole terminal, and outgroups were represented by 
Makalata didelphoides and Echimys chrysurus. The analysis was conducted using four areas of occurrence kept as maximum, ten chains of 5 millions generations, sampling every 100 generations, and discarding $25 \%$ of samples.

We used biomes (biome in the definition of Whittaker 1968: a grouping of communities of similar physiognomy and related environmental conditions within a single continent or region) to delimit the geographic ranges of the living Phyllomys species as follows: AM (the outgroups Makalata didelphoides and Echimys chrysurus); the Cerrado biome ( $P$. brasiliensis, the specimen collected in the core area of Cerrado - UNB 3820, and Phyllomys sp. 4 from areas in the transition of AF and Cerrado); south AF (P. nigrispinus, P. sulinus, and P. dasythrix); south-central AF ( $P$. pattoni, P. lundi, P. mantiqueirensis, Phyllomys. sp. 1, and Phyllomys. sp. 3); northcentral AF (P. pattoni and P. lamarum); northeast AF (Phyllomys sp. 2); and the relicts of AF enclaves in the dry biome Caatinga - called "Brejos" (P. blainvilii). The sense for this regionalization in the distribution of Phyllomys in the AF is based in clades of Phyllomys associated to particular regions of the Atlantic forest (Leite et al. 2003; Loss \& Leite 2011) and also by independent source of evidence for such regionalization of AF biota (Carnaval et al. 2009; Silva et al. 2012). Given that Phyllomys brasiliensis and Phyllomys sp. n. are recorded in transitional areas between Cerrado and AF, we conduct an alternative analyses considering these taxa to occur in transitional areas of Cerrado and AF as well.

\section{Results}

Phylogenetic analysis

The phylogeny resulted from Mr.Bayes analysis (Fig. 1.1) confirmed the monophyly of Phyllomys with high support. The linage that leads to Phyllomys pattoni is derived from a basal dichotomy as the first divergence in Phyllomys tree. The specimens MCN-M 2027, MCN-M 2709 (referred as Phyllomys sp. 4 by Araújo et al. 2014) and UNB 3820 formed a well-supported clade sister to $P$. mantiqueirensis. These specimens display a unique combination of morphological characters, karyotype (Araújo et al. 2014), and distribution. Given these evidences we decided to name a new species as follows in the next sections. Specimens related to Phyllomys sp. 3 formed a well supported clade and is sister to a clade represented by remaining Phyllomys species. This clade is formed by two reciprocally monophyletic 
clades that are represented by two unnamed species, Phyllomys sp. 1 and Phyllomys sp. 2, P. blainvilii, P. lamarum, P. brasiliensis, P. lundi, P. nigrispinus, $P$. sulinus, and $P$. dasythrix. 


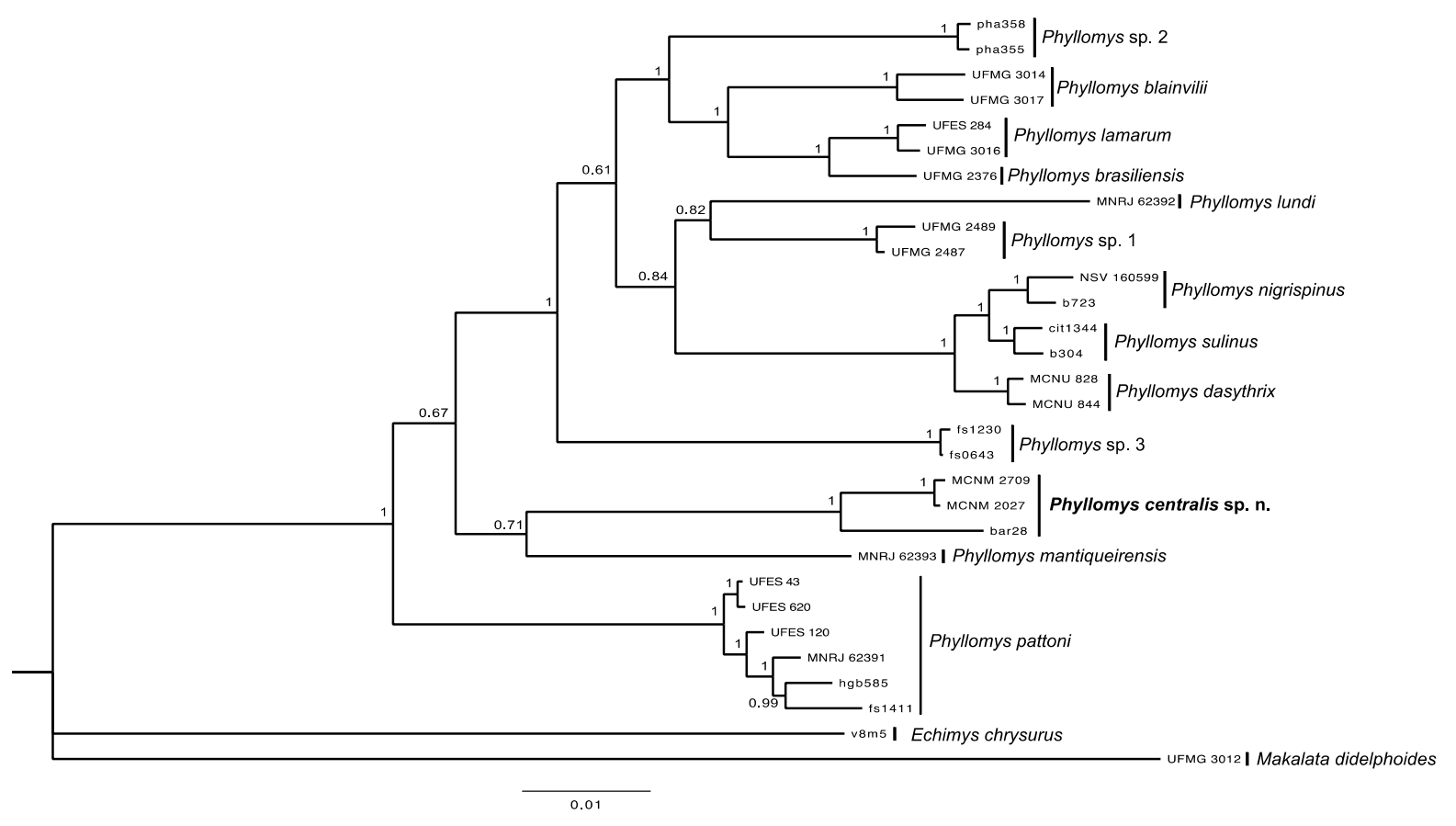

Figure 1.1: Bayesian inference phylogram 1 based on concatenated ( $v W F, G H R, R A G 1, C O I$, and Cytb) molecular data set. Numbers near nodes represent Bayesian posterior probabilities. 


\section{Description of the new species}

Genus Phyllomys Lund, 1839

Phyllomys centralis sp. n. (Fig. 2.1)

Holotype. UNB 3820, adult female; skin, skull, partial skeleton, and tissue in ethanol. Collected by Anderson Paz, 5 March 2012. Deposited in the Mammals collection, Universidade de Brasília (UnB) under the catalog number UNB 3820 cytb sequence, GenBank acc. no. KX852221; COI sequence, GenBank acc. no. KX852223; GHR sequence, GenBank acc. no. KX852229; RAG1 sequence, GenBank acc. no. KX852256; $v W F$ sequence, GenBank acc. no. KX852279.

Type locality. BRAZIL, Distrito Federal, APA Gama Cabeça de Veado, $15^{\circ} 57^{\prime} 04.42 " \mathrm{~S}, 47^{\circ} 57^{\prime} 48.85^{\prime \prime} \mathrm{W}, 1100 \mathrm{~m}$.

Paratypes. MCN-M 2027, young female collected by Kátia R. da Silva, 9 December 2010, BRAZIL, Minas Gerais, Santa Bárbara, 1957'32"S, 4324'54"W (skin, skull, partial skeleton, tissue in ethanol). MCN-M 2709, adult male, collected by Kátia R. da Silva, 26 January 2012, BRAZIL, Minas Gerais, Catas Altas, $20^{\circ} 4^{\prime} 27^{\prime \prime S}, 43^{\circ} 23^{\prime} 53^{\prime \prime W}$ (skin, skull, partial skeleton, tissue in ethanol). MCN-M 2153, adult, sex unknown, collected by Luciana Barçante, BRAZIL, Minas Gerais, Belo Horizonte, $19^{\circ} 49^{\prime} \mathrm{S}, 43^{\circ} 54^{\prime} \mathrm{W}$ (skin, skull, partial skeleton).

Etymology. The name centralis refers to the geographic distribution, which extend to the most central region of BRAZIL compared to the geographic distribution of other Phyllomys species.

Diagnosis. A medium sized species of Phyllomys with coarse dorsal pelage, reddish-brown speckled with black. Pelage color gradually changing to reddish-brown or beige toward the venter, with inguinal, gular and axillary white patches. Dorsal pelage on pes and manus light-brown to silver-white. Aristiforms on rump medium in length (ca. $24 \mathrm{~mm}$ ) and thin $(<0.5 \mathrm{~mm})$, wider and paler at the base, thinning gradually toward the tip, which is either black or orange. Tail shorter than or equal to head and body length, covered with light-brown hairs to the tip, forming a bushy tuft. Upper toothrow parallel to slightly divergent posteriorly; palatine wider than M1. Supraorbital ridges well developed, interorbital region slightly divergent posteriorly. 


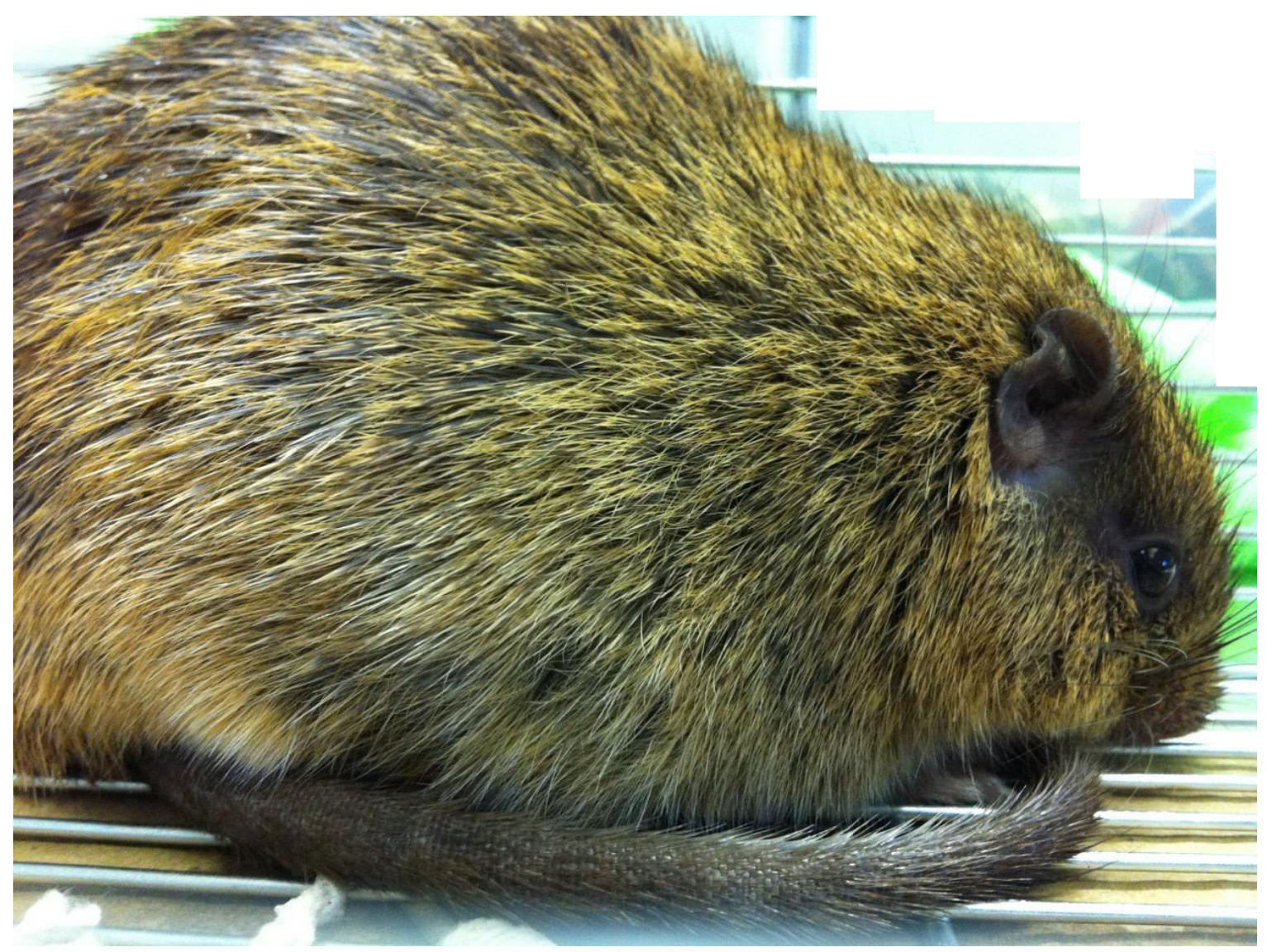

Figure 2.1: Live holotype of Phyllomys centralis sp. n. (UNB 3820) after been captured in a live trap installed in a canopy of gallery forest located in the southern portion of APA Gama Cabeça-de-Veado - Federal District, central Brazil. Foto: André Mendonça. 
Zygomatic arch robust, maximum height approximately equal to or less than one third of jugal length. Postorbital process of zygoma well developed, formed exclusively by the jugal. Lateral process of supraocciptal short, extending to the midline of the external auditory meatus. Incisive foramen ovate, upper incisors orthodont. Karyotype (MCN-M2027): 2n = 76, FN = 140 (Araújo et al. 2013, referred to as "Phyllomys sp. 4").

\section{Description}

External measurements. Female (UnB UNB 3820, holotype). Total body length $471.5 \mathrm{~mm}$, tail $224 \mathrm{~mm}$, hindfoot $43 \mathrm{~mm}$, ear $18.5 \mathrm{~mm}$, weight $340 \mathrm{~g}$. Male (MCN-M 2709, paratype). Total body length $425 \mathrm{~mm}$, tail $211 \mathrm{~mm}$, hindfoot $39 \mathrm{~mm}$, ear 16 $\mathrm{mm}$, weight $250 \mathrm{~g}$. There are no external measurements for the specimen MCNM2153 and the young female MCN-M 2027.

External morphology (Fig. 3.1) Medium sized body (sensu Emmons et al. 2002) with coarse pelage but not heavily spined. Dorsal head color similar to dorsum, nose reddish. Round and small ears densely covered by hairs two times larger than ears. Mystacial vibrissae exceeding the ears, varying from dark brown (MCN-M 2153; 2709) to whitish (UNB 3820). Dorsal pelage ranging from reddish brown (specimen MCN-M 2153) to yellowish brown (specimens UNB 3820; MCN-M 2709), both speckled with black. No clear distinction between dorsal and lateral pelage. Ventral pelage varies from reddish-brown to greyish-beige with inguinal and axillary white patches. Aristiforms on rump short (less than $26 \mathrm{~mm}$ ) and narrow (less than 0,5 mm), paler at the base, gradually darkening toward the distal end. Aristiform tip either black or orange, whiplike tip (filamentum apicalis) present or absent. Tail dark brown above and slightly lighter below, but not conspicuously bicolor; shorter than or equal to head and body length in adult specimens; covered with light brown hairs throughout its length, ending in a bushy tuft. Tail scales visible, especially toward the proximal portion of tail. Dorsal surface of manus and pes covered with light-brown to silverwhite hairs, giving a lighter aspect when compared to the rest of the body. Ungual tufts whitish, reaching claw tips, vestigial pollex bearing a nail. Plantar surface of hindfoot covered by small scales, bearing long hypothenar and thenar pads, and four interdigital pads. 

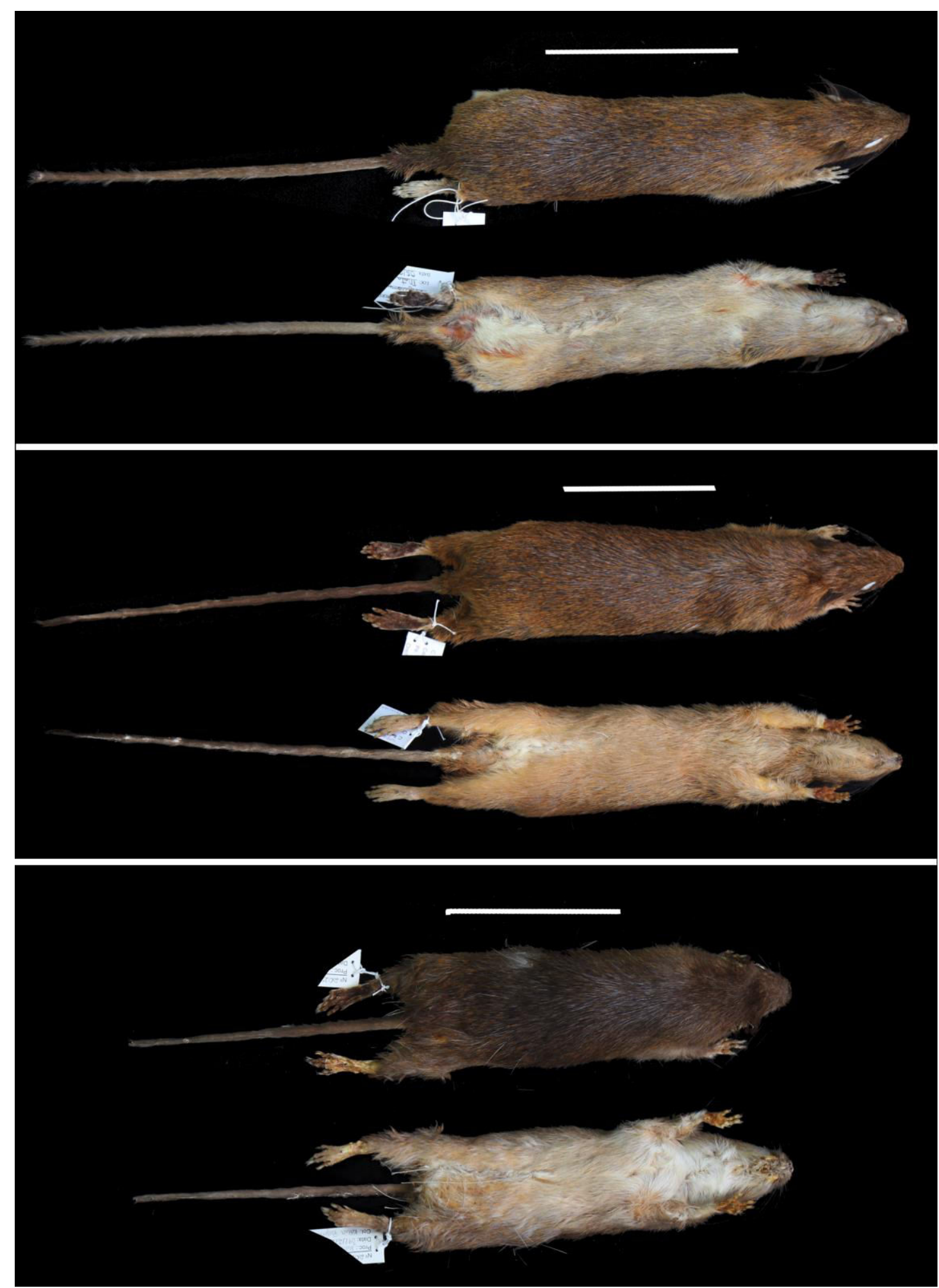

Figure 3.1: Dorsal and ventral views of skins of specimens of Phyllomys centralis sp. n. The holotype (UNB 3820 - above), and two paratypes (MCN-M 2709 - center; MCN-M 2027 - below). Scale bar $=11 \mathrm{~cm}$ 
Cranium (Fig. 4.1). Skull robust and long. Nasal bones widen gradually toward anterior end in dorsal view. Interorbital region diverging posteriorly, with a very small postorbital process. Supraorbital ridges well developed. Zygomatic arch robust, maximum height approximately equal to or less than one third of the jugal length. Postorbital process of zygomatic prominent and formed only by jugal. Incisive foramen ovate present. Palatine width wider than tooth width at M1. Mesopterygoid fossa variable in size and shape, forming an angle of $45-60^{\circ}$, and reaching anterior lamina of M3 or posterior lamina of M2. Lateral process of supraocciptal short, extending to the midline of the external auditory meatus. Ventral root of the angular process laterally deflected or not. Ventral mandibular spine present or absent. Skull measurements presented in Table 1.1.

Dental morphology (Fig. 5.1). Upper incisors orthodont; upper toothrows parallel to slightly divergent posteriorly. Upper cheek teeth rectangular, consisting of 4 simple parallel lophs separated by 3 labial flexi: para-, meta-, and posteroflexus. Lower premolar pentalophodont and lower molars trilophodont. Meso-, postero-, and hypoflexid angled; murid present on $\mathrm{m} 3$ and also visible on worn $\mathrm{m} 2$, separating hypo- and posteroflexid.

Post-cranial skeleton (Figs. 6.1; 7.1): Vertebrae count: 7 cervical, 14 thoracic, 7 lumbar, 3 sacral, and 36 caudal. Dorsal tubercle present on atlas, but smaller than ventral tubercle. Spinous process of axis well developed and projected posteriorly. Lamina ventralis present on sixth cervical vertebra. Neural process of second thoraxic vertebra long and distally broad. Eleventh thoracic vertebra is the anticlinal. Anapophyses present on all but the seventh lumbar vertebra. Second sacral vertebra fused to third and first vertebrae, which is also fused to the ilium. Six proximal caudal vertebrae show well-developed neural and transverse processes, pre- and postzygapophyses, and neural foramen. Sternum formed by a shovel-shaped manubrium, four wide sternebrae, and a rectangular xiphisternum. Scapula with infraspinous fossa wider than supraspinal, cranial border round and vertebral border pointed, spinous process long, acromion and metacromion well developed. Humerus slightly shorter than ulna, deltoid tuberosity well developed positioned on the proximal half. Size of olecranon process similar to trochlear notch. Iliac crest well developed and projected laterally, posterodorsal margin of ischium pointed, sciatic notch well developed. 


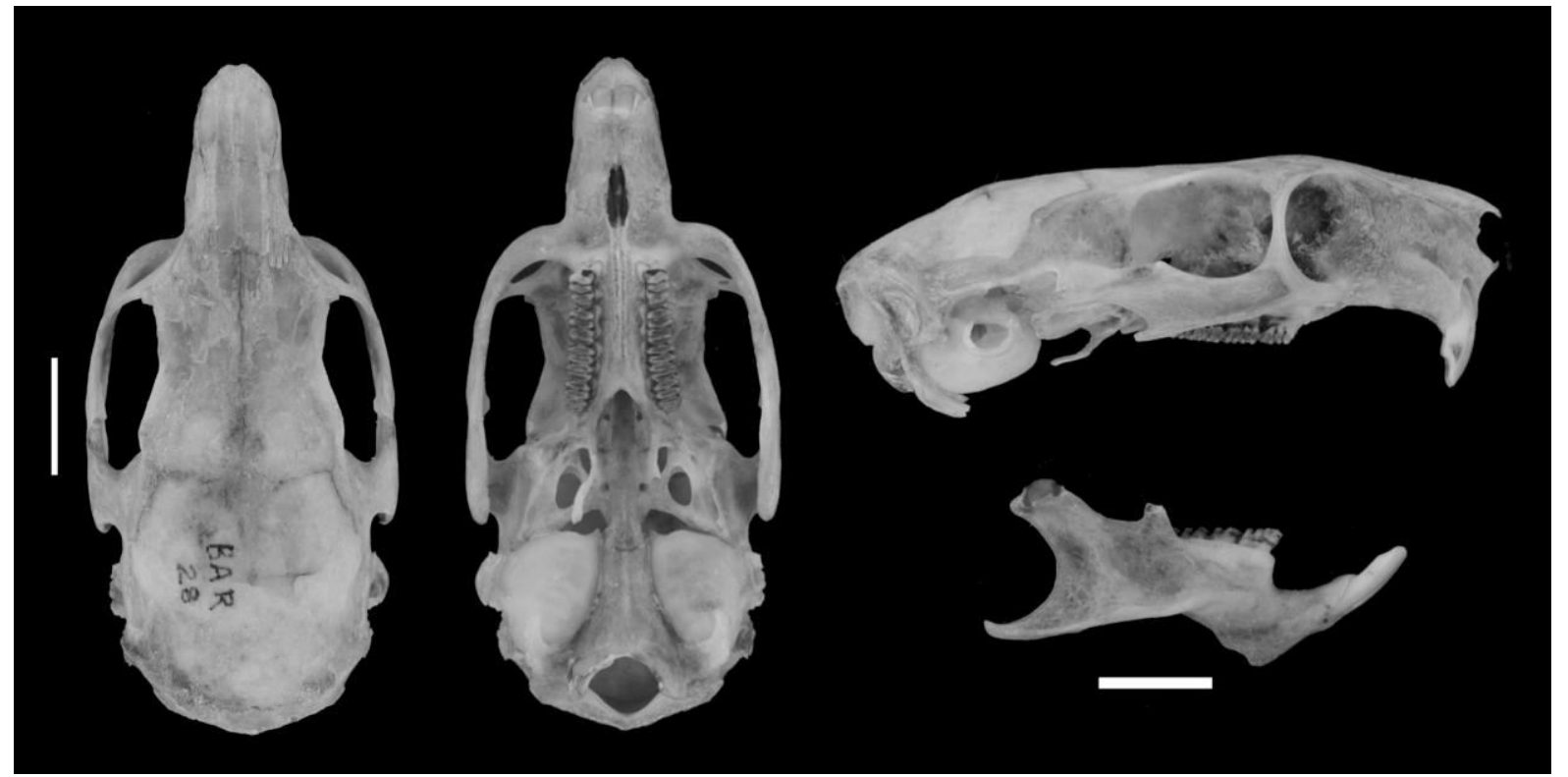

Figure 4.1: Dorsal, ventral, and lateral views of skull and lateral view of mandible of holotype of Phyllomys centralis sp. n. - UNB 3820. (scale bar $=1 \mathrm{~cm}$ ).

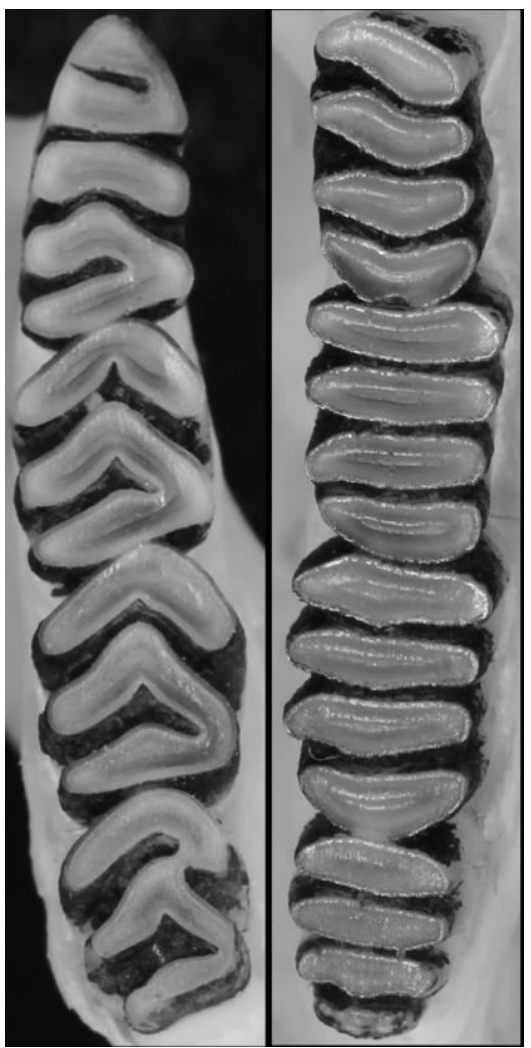

Figure 5.1: Right mandibular (left) and maxillary toothrows of Phyllomys centralis sp. n. (paratype MCN-M2709). 


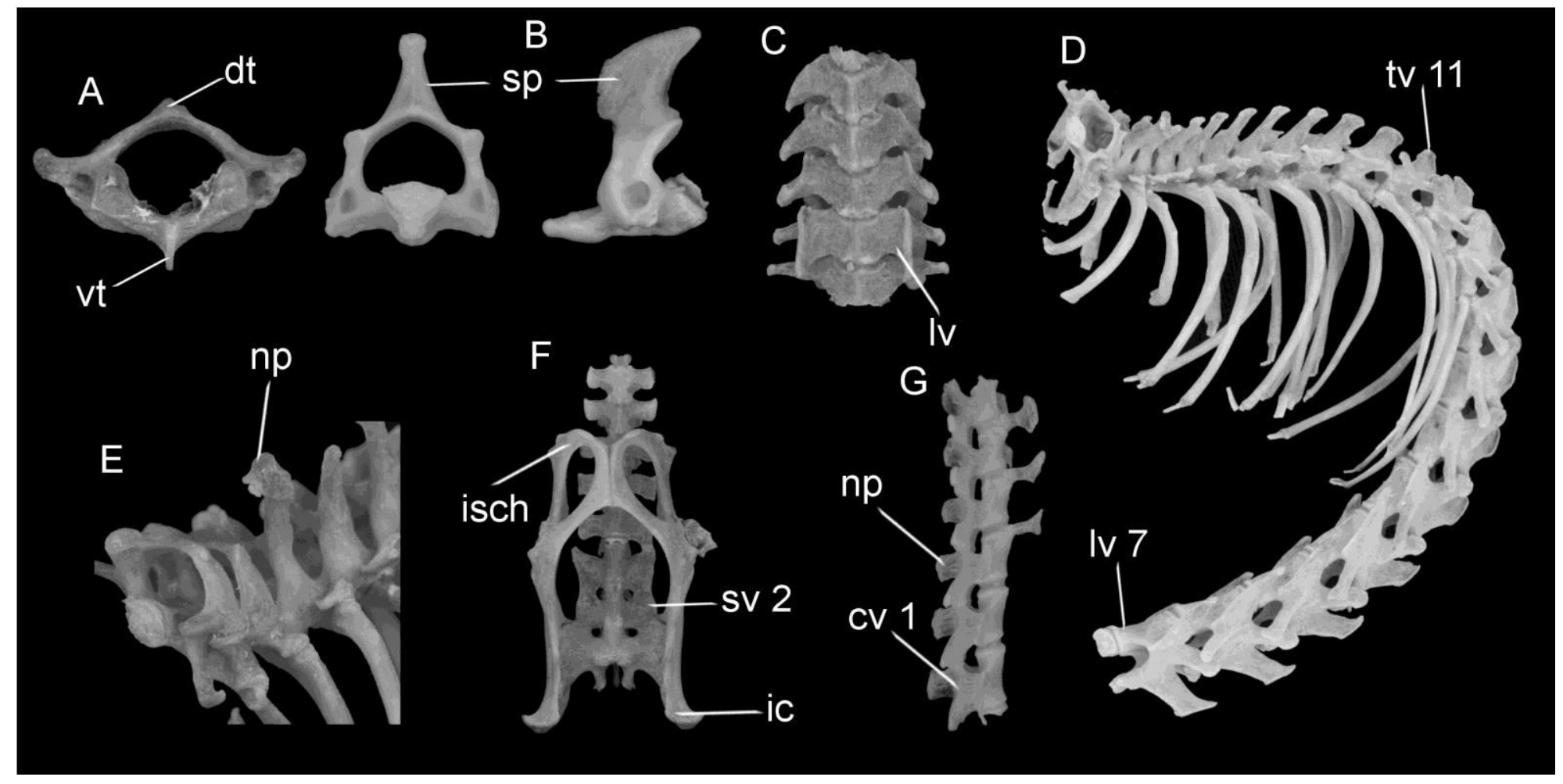

Figure 6.1: Post cranium axial skeleton of Phyllomys centralis sp. $\mathrm{n}$. A - atlas: dorsal tubercle (dt) and ventral tubercle (vt); B - axis: spinous process (sp); C - cervical vertebrae: lamina ventralis (lv) of the sixth cervical vertebra; E - neural process (np) of second thoraxic vertebra; D the eleventh thoracic vertebra (tv11), and the seventh lumbar vertebra (lv7); F - second sacral vertebra (sv2), ischium (isch), and iliac crest (ic); $\mathrm{G}$ - first caudal vertebra (cv1), neural process (np). 


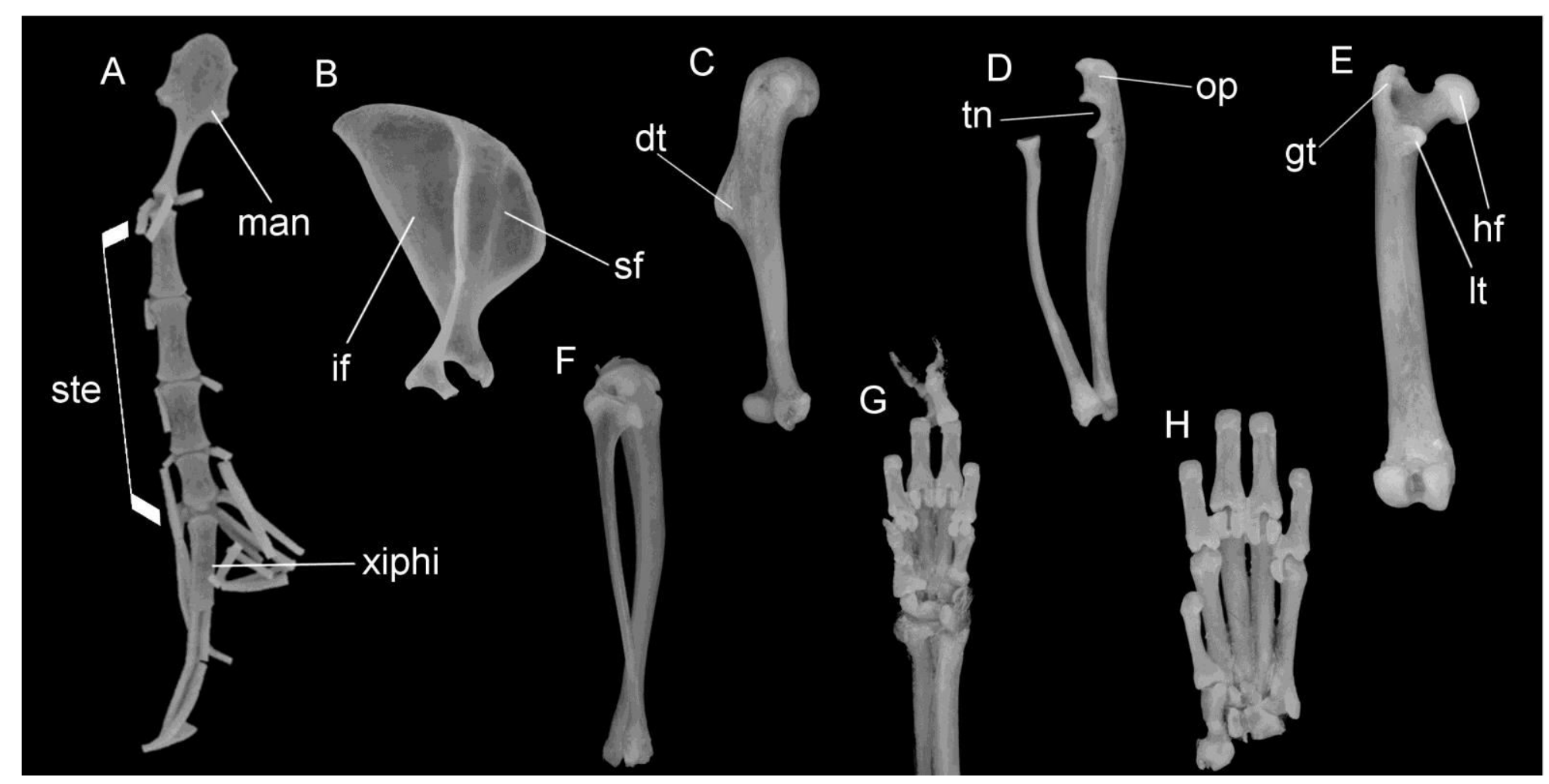

Figure 7.1: Sternum region and appendicular skeleton of Phyllomys centralis sp. $\mathrm{n}$. A - sternum region: sternebrae (ste), manubrium (man), and xiphisternum (xiphi); B - scapula: infraspinous fossa (if), supraspinal fossa (sf); C - humerus: deltoid tuberosity (dt); D - radio and ulna: olecranon process (op), and trochlear notch (tn); E - femur: greater trochanter (gt), head of femur (hf), and lesser trochanter (lt); F - tibia and fibula; $\mathrm{G}$ - manus; $\mathrm{H}$ - pes. 
Table 1.1: Cranial measurements of Phyllomys centralis sp. n. (UNB 3820, MCNM2709, and MCN-M2153), Phyllomys blainvilii, and Phyllomys brasiliensis. Measurements taken from Phyllomys blainvilii, and Phyllomys brasiliensis are the same of Leite (2003).

\begin{tabular}{|c|c|c|c|c|}
\hline & $\begin{array}{l}\text { P. centralis sp. } \mathrm{n} \text {. } \\
\mathrm{n}=3\end{array}$ & $\begin{array}{l}\text { P. mantiqueirensis } \\
\text { (holotype) }\end{array}$ & $\begin{array}{l}\text { P. blainvilii } \\
\mathrm{n}=65\end{array}$ & $\begin{array}{c}\text { P. brasiliensis } \\
\mathrm{n}=2\end{array}$ \\
\hline$\overline{\text { GSL }}$ & $\begin{array}{c}51.85 \\
(50.16-53.93)\end{array}$ & 48.1 & $\begin{array}{c}48.0 \\
(44.4-52.7)\end{array}$ & $\begin{array}{c}50.4 \\
(48.5-52.3)\end{array}$ \\
\hline NL & $\begin{array}{c}15.45 \\
(14.33-16.16)\end{array}$ & 14.2 & $\begin{array}{c}13.7 \\
(11.9-16.6)\end{array}$ & $\begin{array}{c}14.2 \\
(13.8-14.6)\end{array}$ \\
\hline RL & $\begin{array}{c}19.18 \\
(18.4-20.4)\end{array}$ & 17.2 & $\begin{array}{c}16.8 \\
(15.0-18.9)\end{array}$ & $\begin{array}{c}18.6 \\
(17.5-19.8)\end{array}$ \\
\hline $\mathrm{OL}$ & $\begin{array}{c}14.23 \\
(13.88-14.78)\end{array}$ & 14.0 & $\begin{array}{c}13.7 \\
(12.7-14.7)\end{array}$ & $\begin{array}{c}13.8 \\
(13.3-14.3)\end{array}$ \\
\hline RB & $\begin{array}{c}7.9 \\
(7.6-8.16)\end{array}$ & 7.9 & $\begin{array}{c}6.9 \\
(6.2-7.8)\end{array}$ & $\begin{array}{c}7.3 \\
(7.0-7.6)\end{array}$ \\
\hline IOC & $\begin{array}{c}12.47 \\
(11.44-13.19)\end{array}$ & 10.2 & $\begin{array}{c}10.1 \\
(8.8-11.9)\end{array}$ & $\begin{array}{c}11.8 \\
(11.1-12.5)\end{array}$ \\
\hline MB & $\begin{array}{c}20.03 \\
(19.78-20.19)\end{array}$ & 18.9 & $\begin{array}{c}18.8 \\
(17.6-20.5)\end{array}$ & $\begin{array}{c}19.8 \\
(18.5-21.2)\end{array}$ \\
\hline ZB & $\begin{array}{c}25.21 \\
(24.03-27.19)\end{array}$ & 23.1 & $\begin{array}{c}23.0 \\
(20.9-25.3)\end{array}$ & $\begin{array}{c}24.0 \\
(22.6-25.4)\end{array}$ \\
\hline CIL & $\begin{array}{c}47.03 \\
(45.21-48.41)\end{array}$ & 43.0 & $\begin{array}{c}43.1 \\
(40.2-47.3)\end{array}$ & $\begin{array}{c}44.8 \\
(42.0-47.6)\end{array}$ \\
\hline $\mathrm{BaL}$ & $\begin{array}{c}40.45 \\
(38.81-41.63)\end{array}$ & 36.3 & $\begin{array}{c}37.0 \\
(33.4-40.4)\end{array}$ & $\begin{array}{c}39.1 \\
(36.0-42.1)\end{array}$ \\
\hline D & $\begin{array}{c}12.16 \\
(10.37-11.76)\end{array}$ & 10.0 & $\begin{array}{c}9.6 \\
(8.1-11.3)\end{array}$ & $\begin{array}{c}10.7 \\
(10.1-11.2)\end{array}$ \\
\hline MTRL & $\begin{array}{c}11.21 \\
(10.81-11.69)\end{array}$ & 11.4 & $\begin{array}{c}11.4 \\
(10.4-12.7)\end{array}$ & 11.8 \\
\hline PLb & $\begin{array}{c}9.65 \\
(9.22-10.0)\end{array}$ & 9.0 & $\begin{array}{c}8.5 \\
(7.0-9.6)\end{array}$ & $\begin{array}{c}9.8 \\
(9.5-10.2)\end{array}$ \\
\hline IFL & $\begin{array}{c}4.29 \\
(3.86-4.8)\end{array}$ & 3.9 & $\begin{array}{c}3.8 \\
(3.0-4.6)\end{array}$ & $\begin{array}{c}4.8 \\
(4.7-4.8)\end{array}$ \\
\hline $\mathrm{BuL}$ & $\begin{array}{c}11.16 \\
(10.5-11.96)\end{array}$ & 9.4 & $\begin{array}{c}10.2 \\
(9.1-11.8)\end{array}$ & $\begin{array}{c}10.5 \\
(10.1-10.9)\end{array}$ \\
\hline Pla & $\begin{array}{c}19.94 \\
(18.53-21.32)\end{array}$ & 18.9 & $\begin{array}{c}18.1 \\
(15.6-20.4)\end{array}$ & $\begin{array}{c}20.2 \\
(21.4-22.8)\end{array}$ \\
\hline PPL & $\begin{array}{c}23.14 \\
(22.41-23.72)\end{array}$ & 18.7 & $\begin{array}{c}19.6 \\
(17.4-21.5)\end{array}$ & $\begin{array}{c}22.1 \\
(21.4-22.8)\end{array}$ \\
\hline MPF & $\begin{array}{c}5.60 \\
(4.96-6.24)\end{array}$ & 3.1 & $\begin{array}{c}3.2 \\
(2.7-3.6)\end{array}$ & $\begin{array}{c}4.0 \\
(3.5-4.5)\end{array}$ \\
\hline MaxB & $\begin{array}{c}8.73 \\
(8.12-9.22)\end{array}$ & 8.3 & $\begin{array}{c}7.5 \\
(6.4-8.2)\end{array}$ & $\begin{array}{c}8.3 \\
(8.2-8.4)\end{array}$ \\
\hline $\mathrm{OccW}$ & $\begin{array}{c}8.97 \\
(8.77-9.27)\end{array}$ & 8.6 & $\begin{array}{c}8.3 \\
(7.9-9.0)\end{array}$ & $\begin{array}{c}8.5 \\
(8.4-8.6)\end{array}$ \\
\hline $\mathrm{RD}$ & $\begin{array}{c}10.09 \\
(9.42-10.58)\end{array}$ & 9.9 & $\begin{array}{c}10.3 \\
(9.1-11.1)\end{array}$ & $\begin{array}{c}11.1 \\
(10.1-12.1)\end{array}$ \\
\hline CDM1 & $\begin{array}{c}14.93 \\
(14.27-15.39)\end{array}$ & 13.9 & $\begin{array}{c}13.7( \\
12.8-14.9)\end{array}$ & $\begin{array}{c}14.4 \\
(13.7-15.2)\end{array}$ \\
\hline $\mathrm{CD}$ & $\begin{array}{c}20.61 \\
(19.63-22.23)\end{array}$ & 19.7 & $\begin{array}{c}18.5 \\
(16.5-19.9)\end{array}$ & $\begin{array}{c}17.5 \\
(15.0-20.0)\end{array}$ \\
\hline
\end{tabular}


Greater trochanter higher than head of femur, lesser trochanter well developed and third trochanter absent. Tibia slightly longer than femur, sigmoid in anterior view. Proximal margin of fibula wide and falciform. Five digits on manus and pes, vestigial pollex.

Comparisons. Phyllomys centralis sp. n. is clearly diferent from $P$. mantiqueirensis by the larger cranial mesurements (Table 1.1) and body size (Table 2.1). The former has the doral pelage with a spiny aspect and broad palatine width, and $P$. mantiqueireis posses a soft dorsal pelage (Table 2.1) and narrow palatine width (Table 2.1). These two species posses a disjunct known geographical distribution. The geographic range of Phyllomys centralis sp. n. overlaps with $P$. brasiliensis and is adjacent to $P$. blainvilii. These three species are morphologically similars and overlaps in many cranial mensurements (Table 1.1). The overall dorsal pelage is darker in Phyllomys centralis sp. n. than in P. blainvilii, and the thighs and rump of Phyllomys centralis sp. n. are darker than those of P. brasiliensis. Aristiforms on rump of Phyllomys centralis sp. n. narrower $(<0.5 \mathrm{~mm})$ than both P. brasiliensis and P. blainvilii ( $\geq 1 \mathrm{~mm})$, of the same length of the latter (ca. $24 \mathrm{~mm})$, and shorter than the former (ca. $27 \mathrm{~mm}$ ). Transition from dorsal to ventral sides of the body more gradual in Phyllomys centralis sp. n. than in P. brasiliensis and P. blainvilii. The ventral pelage is lighter in P. brasiliensis and P. blainvilii than in Phyllomys centralis sp. n., which varies from reddish-brown to greyish-beige. The palate is about the same width of M1 in P. brasiliensis, but wider than M1 in both Phyllomys centralis sp. $\mathrm{n}$. and in P. blainvilii (Table 2.1). The orange band of dorsal aristiforms is also shorter in Phyllomys centralis sp. n. than the other two species. Posterior margin of protoconid on m3 slightly pointed in Phyllomys centralis sp. n. and rounded in P. brasiliensis. Usefull traits to delimit $P$. centralis sp n., $P$. mantiqueirensis, $P$. brasiliensis, and $P$. blainvilii are presented in Table 2.1 .

Distribution and habitat. The holotype Phyllomys centralis sp. n. was trapped in a live trap placed in the canopy of a protected gallery forest fragment within Fazenda Água Limpa, research station of Universidade de Brasília at conservation unit APA Gama Cabeça-de-Veado (Distrito Federal, central Brazil). This gallery forest fragment comprises a typical gallery forest vegetation with arboreal individuals of 20 
to $25 \mathrm{~m}$ high, distributed alongside a narrow affluent of Paraná hydrographic region, and canopy covering 70 to $95 \%$ of the landscape. It is located nearby a small dam and is surrounded by savannas-like vegetation of Cerrado core area and urban occupation. The collecting localities of three paratypes are located at western limit of AF. Vegetation from these localities are characterized by deciduous and semi-deciduous forests, savannas, and gallery forests.

Table 2.1: Table showing selected characters used to delimit $P$. centralis $\mathrm{sp}$. $\mathrm{n}$. in relation to the sister species ( $P$. mantiqueirensis), and species with closer geographic records: $P$. blainvilii and $P$. brasiliensis

\begin{tabular}{lllll}
\hline & P. centralis sp. n. & P. mantiqueirensis & P. blainvilii & P. brasiliensis \\
\hline Body size & medium & small & Small-medium & medium \\
Dorsal pelage & spiny & soft & spiny & spiny \\
Palatine width & $>\mathrm{M} 1$ & $<\mathrm{M} 1$ & $>\mathrm{M} 1$ & $<\mathrm{M} 1$ \\
Aristiforms width & $<0.5 \mathrm{~mm}$ & $<0.5 \mathrm{~mm}$ & $\geq 1.0 \mathrm{~mm}$ & $\geq 1.0 \mathrm{~mm}$ \\
Karyotype & $2 \mathrm{n}=74 \mathrm{FN}=140$ & - & $2 \mathrm{n}=50 \mathrm{FN}=94$ & - \\
\hline
\end{tabular}

\section{Molecular dating and Biogeographic analyses}

Molecular dating analysis (Fig. 8.1) indicates the initial diversification of Phyllomys to occur during the Miocene, when it shares the MRCA with Echimys. The crown age of Phyllomys is the late Miocene, and most diversification events within the genus occurred during the Pliocene, when Phyllomys centralis sp. n. derived from a divergence event in middle Pliocene, a time when it split from the MRCA shared with $P$. mantiqueirensis. Additional species derived from divergences occurred during the Pliocene are the unnamed species Phyllomys sp. 2 and Phyllomys sp. 3. Most living species of Phyllomys resulted from divergences during Pleistocene, as the two major clades composed by species distributed at northeast and southern Brazil (see Loss \& Leite 2011).

Ancestral geographic distribution analyses using different distribution areas (i.e. setting the geographic range of Phyllomys centralis sp. n. and P. brasiliensis to Cerrado and transition with AF, or Cerrado only) resulted in congruent results. This analysis (Fig. 9.1) indicate the south-central AF as the main area for the initial 
diversification of Phyllomys. During Miocene an ancestral stock have changed its geographic distribution from (what is currently known as) AM to south-central AF. After an impressive event of diversification, other lineages shifted their distribution to other biomes or to sub-areas of the AF, including Phyllomys centralis sp. n. which is distributed in the Cerrado and transitional areas between Cerrado and AF.

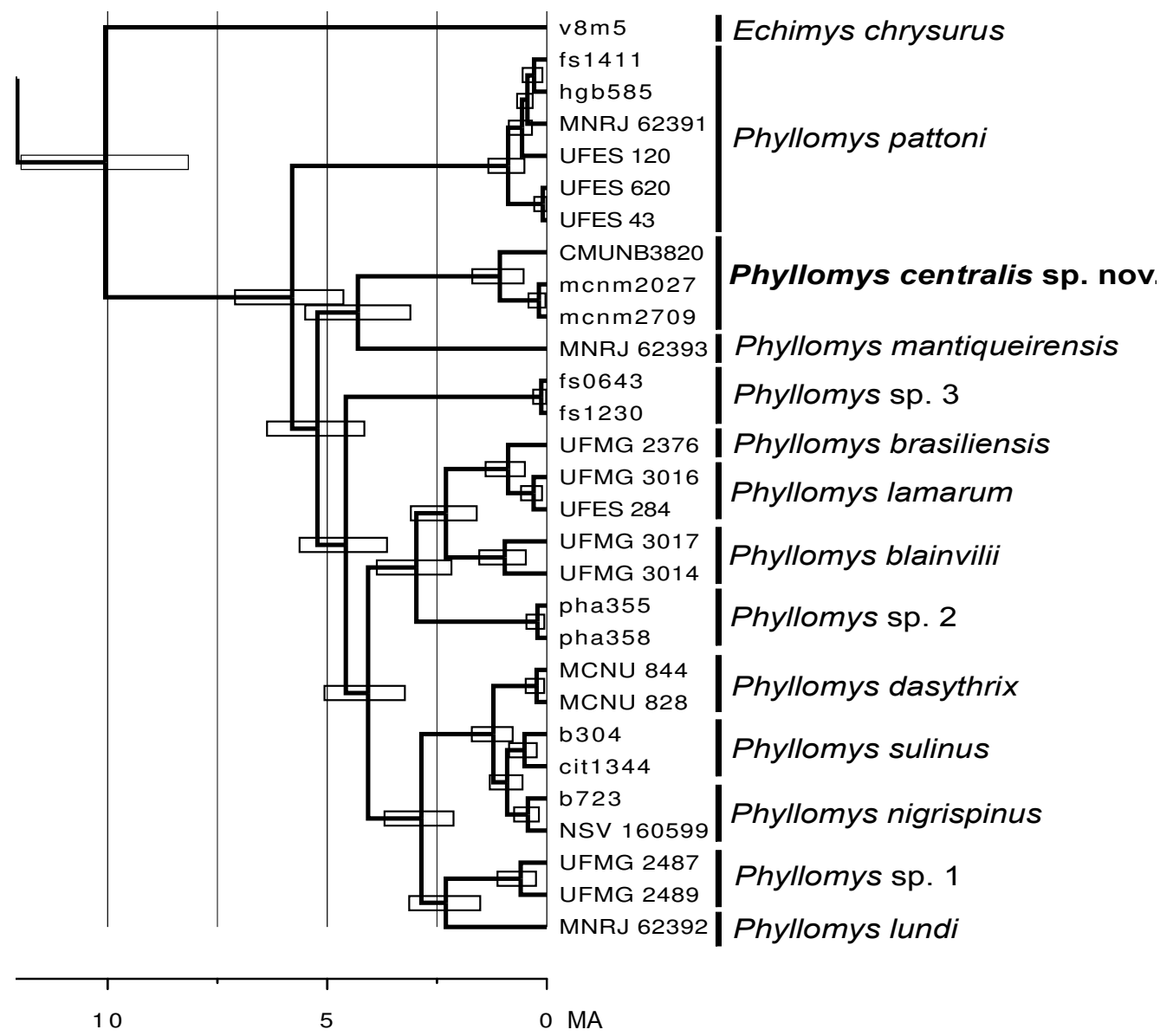

Figure 8.1: Molecular dating chronogram of Phyllomys inferred from concatenated genes ( $v W F, G H R, R A G 1$, and Cytb). Horizontal bars represent 95\% credibility intervals for time estimates. 


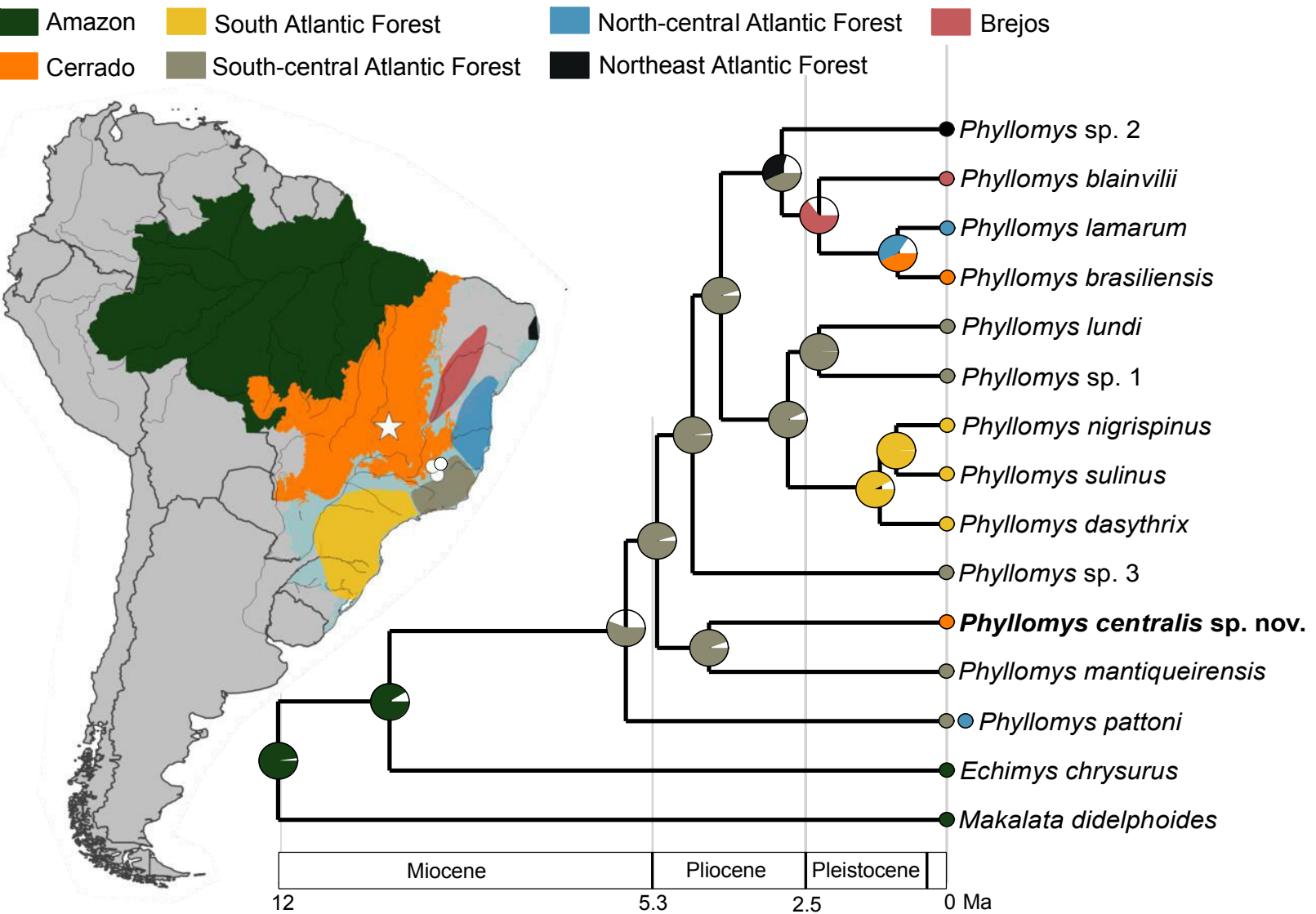

Figure 9.1: Map of South America showing the limits of the Cerrado, Amazon, and Atlantic Forest biomes. The Atlantic Forest is depicted in sub-regions (see Material and methods for detail). The red polygon refer to the geographic distribution of Phyllomys blainvilii, which is distributed in the relict of Atlantic Forest (Brejos). White star and circles represent collection localities of specimens of Phyllomys centralis sp. n. used in molecular analyses. White star represent the type locality (Brasília, Federal District - Brazil) of Phyllomys centralis sp. $\mathrm{n}$. The chronogram is the result of molecular dating analysis inferred from concatenated genes $(\nu W F, G H R, R A G 1$, and $C y t b)$. Colored circles near terminal names refers to geographical distribution of each taxon accordingly to associated biomes. Pie chart shows approximate probabilities of ancestral area distribution (only areas with probabilities higher than $30 \%$ are shown). Geological time limits are based in Gibbard et al. (2010). 


\section{Discussion}

Phyllomys centralis $\mathrm{sp} . \mathrm{n}$. here described was assessed over a robust molecular sampling, and is accompanied by karyotype and dense morphological information. We provide a description of the post-cranium skeleton and improve the comprehension of axial and appendicular Phyllomys structures. Information on postcranium skeleton is poorly known in Phyllomys, and considering the significant overlapping of morphological characters between species within this genus (Leite 2003), the information generated here could be useful for future morphological comparisons within the genus. Defining morphological boundaries is historically a major constraint in the systematics and taxonomy of Phyllomys species, and only in recent years the limits among valid species became more clearly recognized (Emmons et al. 2002, Leite 2003). A major limitation in studying Phyllomys is the difficulty to capture arboreal herbivorous echimyids using traditional traps (Voss \& Emmons 1996). Consequently, long time and huge efforts are needed to accumulate representative series leading to most species descriptions being based in few specimens (e.g. P. kerri) (Emmons et al. 2002; Leite 2003). Thus, the phylogenetic approach has been crucial to clarifying Phyllomys taxonomy.

In respect to phylogenetic hypothesis regarding Phyllomys spp., early studies based in mitochondrial data yielded low resolution in Phyllomys tree (Leite 2003) leading to a basal polytomy attributed to rapid events of diversification. Later, multigene phylogenies improved the resolution in Phyllomys tree (Loss \& Leite 2011), evidencing the role of dense molecular data in the phylogenetic method applied to this genus. Low resolution levels are very common in Phyllomys phylogenies and, in fact, it is a pattern found in the entire family Echimyidae, implicating in a star-like phylogeny based in mitochondrial data (Lara et al. 1996; Leite \& Patton 2002) and unresolved internal nodes based in multi-gene approaches (Galewski et al. 2005; Upham \& Patterson 2015). We expand the matrix available to Phyllomys phylogeny by adding more DNA markers and specimens' samples. Even with the robust DNA dataset we produced in the present study - perhaps the largest molecular data used in a Phyllomys phylogeny - low support values can be found. In this view, a forward step to overcome this issue would be the use of combined morphological and molecular 
information in a total-evidence approach, as well as the use of Phylogenomic methods.

The ancestral ranges reconstruction and the dated phylogeny of Phyllomys and its close relatives Echimys and Makalata indicate that an ancestral lineage of Phyllomys shifted its distribution from the AM to the south-central AF, in the middle Miocene. This condition implies in the existence of a past forested connection suitable for the occurrence and dispersal of echimyids climbing rats linking the AM and AF in the region where the southern part of the Cerrado biome is currently located. This hypothesis is in accordance with previous proposed southern/central connection between AF and AM (Por 1992; Costa 2003). Costa (2003) found a number of lineages of small mammals distributed in the AF as sisters to lineages distributed in $\mathrm{AM}$, and sister lineages with disjunct distributions in the AF and forest environments of the Cerrado region. Many taxa analyzed in Costa (2003) display similar geographic distribution of the species analyzed here, and the ancient divergence times (e.g. $8 \mathrm{Ma}$ ) estimated for some of these lineages are closer to the coalescent time of the most recent common ancestor of Phyllomys and the sister Echimys (10 Ma) found here. Others sources of evidence based in phylogenetic information and bird communities also indicate old connections between lineages distributed in the southern AF and AM (Batalha-Filho et al. 2013). Our hypothesis coupled with these independent data sources suggest the existence of a paleo-forest during the Miocene covering the current south-central Cerrado area. This condition can be also hypothesized based in Angiosperm families data as well, which support similarities and old ages for the origins of both AF and AM (IBGE 2012), and pollen data sustaining an analogous environment to the current AM rainforest since the Eocene (Burnham \& Johnson 2004) and throughout the Miocene (Jaramillo et al. 2010) in South America. Furthermore, phylogenetic evidence also based in woody plants indicates that organisms from forested environments of South America are older than their relatives from open formations (e. g. savannas) (Souza-Neto et al. 2016), which indicates rainforests paleo-habitats suitable for the diversification of climbing echimyids.

Another connection between the AF and AM is thought to have occurred in the northeastern Brazil (Andrade-Lima 1982; Auler et al. 2004; Bigarella et al. 1975; Wang et al. 2004) where currently the semi-arid Caatinga is the dominant ecosystem. Such contact apparently took place during the Quaternary when mesic conditions may 
have favored the expansion of forest environments (Auler et al. 2004; Wang et al. 2004). Additionally, the current humid forest enclaves within the Caatinga (called "brejos de altitude") are considered as relicts of an extinct ever-green paleo-forest (Rizzini 1963; Bigarella et al. 1975; Andrade-Lima 1982) in that region. This route may have played a minor role in the historic range of Phyllomys species as a whole, but this dynamics of contraction and expansion of forests in this region may have caused speciation leading to Phyllomys blainvilii, which is clearly associated with "brejos de altitude" and seemingly resulted from a dichotomy occurred in the Quaternary.

Multiple contact events at different times may have occurred between AM and AF (Costa 2003; Batalha-Filho et al. 2013). In fact, the borderlines of these two forested environments can not be dissociated from the boundaries of the adjacent biomes, the dry and open Caatinga, Cerrado, and Chaco. Plant elements of AM and AF penetrate into the Cerrado domain (Oliveira-Filho \& Ratter 2002; Marimon et al. 2006), indicating a dynamic history of contact acting on the distribution limits of these biomes. Such patches of forest in the Cerrado biome have been considered as the habitat type enclosing the highest diversity of birds and mammals within the Cerrado, and composed by lineages derived from the adjacent forested biomes (Mares et al. 1985; Silva 1995; Marinho-Filho et al. 2002). Our findings of a new forest dwelling species reinforce this idea. Moreover, the dated phylogeny and ancestral range reconstruction analyses indicate an in situ speciation in such forest patches derived from an ancient divergence and implying that forest expansion and contractions took place during the Tertiary. This is much older than what is predicted by the Refuge hypothesis (Haffer 1969; Vanzolini \& Williams 1981), where the contraction and expansion of forest environments during last glacial and inter-glacial maximum were stated as major drivers for speciation in the Neotropics. Although refuges as a mechanism of isolation and posterior differentiation is a relatively well accepted hypothesis, recent studies have shown minor influences of the last glacial and inter-glacial periods to the diversification of small mammals (e.g. Leite et al. 2016), indicating more ancient geological and climatic events to cause such diversification (Moritz et al. 2000).

Little is known regarding the geographic distribution of Phyllomys centralis sp.n. The holotype was collected at Área de Proteção Ambiental (APA) Gama 
Cabeça-de-Veado, located in the southern portion of Federal District, central Brazil. Although APA means Environmental Protection Area, this is a category of conservation units (defined by the Brazilian national system of conservation unities SNUC; MMA 2011) that allows various types of use of natural resources and even urbanization. Two paratypes were collected in the neighbor cities Santa Bárbara and Catas Altas - in the heart of the iron mining area of Minas Gerais state (MG), once covered by a mosaic of cerrados and forested areas. The last specimen was gathered within the metropolitan area of Belo Horizonte - MG. Thus only the holotype was collected in a relatively protected conservation area that represents an island of native cerrados surrounded to the north and northwest by the urban and suburban areas of Brasília and to the south and southeast by large areas of monoculture farms and agriculture. Even this island of protected native cerrados is always under the threat of wildfire events, which may drastically affect their forested habitats (Mendonça et al. 2015). The expansion of the road system of Brasília is also a threat to the conservation of water resources and associated biota of that site (UNESCO 2003).

We compared data of Phyllomys centralis sp. n. to the IUCN recommendations regarding threat categories (IUCN, 2016). The extent of occurrence of Phyllomys centralis sp. n. was estimated to be $7,499 \mathrm{~km}^{2}$. Under the B1 criteria of IUCN, a species must score the extent of occurrence up to $20,000 \mathrm{~km}^{2}$ to be considered "Vulnerable" and the known geographic occurrence of this species is limmited to four locations, which is considered "Endangered" by the IUCN (criteria B-a) in the case of some of these locations being threatened by an abrupt habitat loss (e.g. fire, hurricane, flood, volcanic eruption, landslide etc). There is no additional information regarding population data of Phyllomys centralis sp. n., so it is impossible to check for the remaining IUCN criteria (criteria A, C, D, and E). IUCN (2016) recommends not to consider a taxon under "Data Deficient" if all of the five criteria have not been considered. Instead, a taxon must be considered as "Not Evaluated" if no attempt to evaluate the current status of the taxon has been made. Under this circumstances we believe that the category "Near Threatened" is adequate because Phyllomys centralis sp. n. scores two items close to the "Vulnerable" category and three locations of occurrence of this species are threatened by abrupt habitat loss (i.e. landslides in mines sites, wildfires, and expansion planning of the road system located at the southern portion of the Federal District). 
In summary, the new species of Phyllomys described here indicate a historic relationship of the forest habitats of Cerrado with AF and AM. Our results also indicate a past link between $\mathrm{AF}$ and $\mathrm{AM}$, and reinforce the hypothesis that the southern and central region of the Cerrado may have been covered by a forest environment during late Miocene and early Pliocene permiting faunal interchanges between the two major forested biomes of South America. A tentative evaluation of this new species under IUCN categories of threat indicates that Phyllomys centralis sp. n. could be considered as "Near Threatened" but additional field surveys to assess populational status are necessary for a more adequate evaluation of the conservation status of this new species. 


\section{References}

Ab'Saber, A. N. (1977). Os domínios morfoclimáticos na América do Sul: primeira aproximação. Geomorfologia, 52, 1-22.

Adkins, R. M., Gelke, E. L., Rowe, D. \& Honeycutt, R. L. (2001). Molecular phylogeny and divergence time estimates for major rodent groups: evidence from multiple genes. Molecular Biology and Evolution, 18, 777-791.

Andrade-Lima, D. (1982). Present-day forest refuges in northeastern Brazil. In G. T. Prance (Ed.), Biological diversification in the Tropics (pp. 245-251). New Yourk: Columbia University Press.

Antoine, P. -O., Marivaux, L., Croft, D. A., Billet, G., Ganerød, M., Jaramillo, C., Martin, T., Orliac, M. J., Tejada, J., Altamirano, A. J., Duranthon, F., Fanjat, G., Rousse, S. \& Gismondi, R. S., (2012). Middle Eocene rodents from Peruvian Amazonia reveal the pattern and timing of caviomorph origins and biogeography. Proceedings of the Royal Society B Biological Sciences, 279, 1319-1326.

Araújo, N. P., Loss, A. C., Cordeiro-Junior, D. A., Silva, K. R., Leite, Y. L. R. \& Svartman, M. (2014). New karyotypes of Atlantic tree rats, genus Phyllomys (Rodentia: Echimyidae). Genome, 57, 1-8.

Argot, C. (2004). Functional-adaptive features and palaeobiologic implications of the postcranial skeleton of the late Miocene sabretooth borhyaenoid Thylacosmilus atrox (Metatheria). Alcheringa: An Australasian Journal of Palaeontology, 28, 229-266.

Auler, A. S., Wang, X., Edwards, R. L., Cheng, H., Cristalli, P. S., Smart, P. L. \& Richards, D. A. (2004). Quarternary ecological and geomorphic changes associated with rainfall events in presently semi-arid northeastern Brazil. Journal of Quaternary Science, 19, 693-701.

Batalha-filho, H., Fjeldsa, J., Fabre, P. \& Miyaki, C. Y. (2013). Connections between the Atlantic and the Amazon forest avifaunas represent distinct historical events. Journal of Ornithology, 154, 41-50.

Bigarella, J. J., Andrade-Lima, D. \& Riehs, P. J. (1975). Considerações a respeito das mudanças paleoambientais na distribuição de algumas espécies vegetais e animais no Brasil. In J. J. Bigarella \& R. D. Becker (Eds.), Simpósio 
internacional sobre o Quaternário (411-464). Curitiba - Porto Alegre: Anais da Acadeia Brasileira de Ciências.

Bruford, M. W., Hanotte, O., Brookfield, J. F. Y, \& Burke, T. (1992). Single-locus and DNA fingerprinting. In A. R. Hoelzel (Ed), Molecular Genetic Analyses of Populations: a Pratical Approach (225-269). IRL Press, Oxford.

Burnham, R. J. \& Johnson, K. R. (2004). South American palaeobotany and the origins of neotropical rainforests. Philosophical Transactions of the Royal Society of London. Biological Sciences, 359, 1595-1610.

Carnaval, A. C., Hickerson, M. J., Haddad, C. F. B., Rodrigues, M. T. \& Moritz, C. (2009). Stability Predicts Genetic Diversity in the Brazilian Atlantic Forest Hotspot. Science, 323, 785-789.

Carrizo, L. V. \& Díaz, M. M. (2013). Descripción Morfológica del esqueleto axial de Filotinos (Rodentia : Sigmodontinae): aspectos morfofuncionales y filogenéticos. Mastozoología Neotropical, 20, 7-29.

Costa, L. P. (2003). The historical bridge between the Amazon and the Atlantic Forest of Brazil : a study of molecular phylogeography with small mammals. Journal of Biogeography, 30, 71-86.

Darriba, D., Taboada, G. L., Doallo, R. \& Posada, D. (2012) jModelTest 2: more models, new heuristics and parallel computing. Nature Methods, 9, 772-772.

Drummond, A. J., Suchard, M. A., Xie, D., \& Rambaut, A. (2012). Bayesian phylogenetics with BEAUti and the BEAST 1.7. Molecular Biology and Evolution, 29, 1969-1973.

Emmons, L. H., Leite, Y. L. R., Kock, D. \& Costa, L. P. (2002). A Review of the Named Forms of Phyllomys (Rodentia: Echimyidae) with the Description of a New Species from Coastal Brazil. American Museum Novitates, 3380, 1-40.

Fouquet, A., Recoder, R., Teixeira, M., Cassimiro, J., Cecília, R., Camacho, A., Damasceno, R., Carnaval, A. C., Moritz, C. \& Rodrigues, M. T. (2012). Molecular phylogeny and morphometric analyses reveal deep divergence between Amazonia and Atlantic Forest species of Dendrophryniscus. Molecular Phylogenetics and Evolution, 62, 826-838.

Galewski, T., Mauvrey, J. F., Leite, Y. L. R., Patton, J. L. \& Douzery, E. J. P. (2005). Ecomorphological diversification among South American spiny rats (Rodentia; Echimyidae: a phylogenetic and chronological approach. Molecular 
Phylogenetics and Evolution, 34, 601-615.

Gibbard, P. L., Head, M. J. \& Walker, M. J. C. (2010). Formal ratification of the Quaternary system/period and the Pleistocene series/epoch with a base at 2.58 ma. Journal of Quaternary Science, 25, 96-102.

Haffer, J. (1969). Speciation in Amazon forest birds. Science, 165, 131-137.

Huchon, D., Catzeflis, F. M. \& Douzery, E. J. P. (1999). Molecular evolution of the nuclear von Willebrand Factor gene in Mammals and the Phylogeny of Rodents. Molecular Biology, 16, 577-589.

Huelsenbeck, J. P. \& Ronquist, F. (2001). MRBAYES: Bayesian inference of phylogenetic trees. Bioinformatics, 17, 754-755.

Iack-ximenes, G. E., Vivo, M. \& Percequillo, A. R. (2005). A new genus for Loncheres grandis Wagner, 1845, with taxonomic comments on other arboreal echimyids (Rodentia, Echimyidaea). Arquivos Do Museu Nacional, 63, 89-112.

IBGE. (2012). Manual Técnico da Vegetação Brasileira. Série Manuais Técnicos em Geociências 1. IBGE, Rio de Janeiro, Brasil.

IUCN Standards and Petitions Subcommittee (2016). Guidelines for Using the IUCN Red List Categories and Criteria: Version 12. Available from http://www.iucnredlist.org/documents/RedListGuidelines.pdf.

Ivanova, N. V., Zemlak, T. S., Hanner, R. H. \& Hebert, P. D. N. (2007). Universal primer cocktails for fish DNA barcoding. Molecular Ecology Notes, 7, 544-548.

Jaramillo, C., Hoorn, C., Silva, S. A. F., Leite, F., Herrera, F., Quiroz, L., Dino, R. \& Antonioli, L. (2010). The origin of the modern Amazon rainforest: implications of the palynological and palaeobotanical record. In C. Hoorn \& F. P. Wesselingh (Eds.), Amazonia, Landscape and Species Evolution: A Look into the Past, 1st edition (pp. 317-334). Blackwell Publishing.

Lara, M. C., Patton, J. L. \& Silva, M. N. F. (1996). The simultaneous diversification of South American echimyid rodents (Hystricognathi) based on complete cytochrome b sequences. Molecular Phylogenetics and Evolution, 5, 403-413.

Leite, Y. L. R. (2003). Evolution and Systematics of the Atlantic tree rats, genus Phyllomys (Rodentia, Echimyidae), with description of two new species, 132, 1118.

Leite, Y. L. R., Christoff, A. U. \& Fagundes, V. (2008). A new species of Atlantic Forest tree rat, genus Phyllomys (Rodentia, Echimyidae) from southern Brazil. 
Journal of Mammalogy, 132, 1-118.

Leite, Y. L. R., Costa, L. P., Loss, A. C., Rocha, R. G., Batalha-Filho, H., Bastos, A. C., Quaresma, V. S., Fagundes, V., Paresque, R., Passamani, M. \& Pardini, R. (2016). Neotropical forest expansion during the last glacial period challenges refuge hypothesis. Proceedings of the National Academy of Sciences, 113, 10081013.

Leite, Y. L. R. \& Patton, J. L. (2002). Evolution of South American spiny rats (Rodentia, Echimyidae): the star-phylogeny hypothesis revisited. Molecular Phylogenetics and Evolution, 25, 455-64.

Loss, A. C. \& Leite, Y. L. R. (2011). Evolutionary diversification of Phyllomys (Rodentia: Echimyidae) in the Brazilian Atlantic Forest. Journal of Mammalogy, 92, 1352-1366.

Loss, A. C., Moura, R. T. \& Leite, Y .L. R. (2014) Unexpected phylogenetic relationships of the painted tree rat Callistomys pictus (Rodentia: Echimyidae). Natureza on Line, 12, 132-136.

Mares, M. A., Willig, M. R. \& Lacher, T. E. J. (1985). The Brazilian Caatinga in South American Zoogeography: tropical mammals in a dry rgion. Journal of Biogeography, 12, 57-69.

Marimon, B. S., Lima, E de, Duarte, T. G., Chieregatto, L. C. \& Ratter, J. A. (2006). Observations on the Vegetation of Northeastern Mato Grosso, Brazil. Iv. an Analysis of the Cerrado-Amazon Forest Ecotone. Edinburgh Journal of Botany, $63,323-341$.

Marinho-filho, J., Rodrigues, F. H. G. \& Juarez, K. M. (2002). The Cerrado Mammals: Diversity, Ecology, and Natural History. In P. S. Oliveira \& R. J. Marquis (Eds.), The Cerrados of Brazil: Ecology and Natural History of a Neotropical Savanna (pp. 266-284). New York, NY: Columbia University Press.

Mendonça, A. F., Armond, T., Camargo, A. C. L., Camargo, N. F., Ribeiro, J. F., Zangrandi, P. L. \& Monteiro, E. V. (2015). Effects of an extensive fire on arboreal small mammal populations in a neotropical savanna woodland. Journal of Mammalogy, 92, 368-379.

MMA - Ministério do Meio Ambiente (2011) SNUC - Sistema Nacional de Unidades de Conservação da Natureza: Lei no 9.985, de 18 de julho de 2000; Decreto no 4.340, de 22 de agosto de 2002; Decreto no 5.746, de 5 de abril de 2006. Plano 
Estratégico Nacional de Áreas Protegidas: Decreto no 5.758, de 13 de abril de 2006. Brasília: Ministério do Meio Ambiente.

Moritz, C., Patton, J. L., Schneider, C. J. \& Smith, T. B. (2000). Diversification of Rainforest Faunas: An intergrated molecular approach. Annual Review of Ecology and Systematics, 31, 533-563.

Myers, N., Mittermeier, R. A., Mittermeier, C. G., Fonseca, G. A. B. \& Kent, J. (2000). Biodiversity hotspots for conservation priorities. Nature, 403, 853-858.

Olivares, A. I. \& Verzi, D. H. (2015). Systematics, phylogeny and evolutionary pattern of the hystricognath rodent Eumysops (Echimyidae) from the PlioPleistocene of southern South America. Historical Biology: an International Journal of Paleobiology, 27, 1042-1061.

Oliveira-Filho, A. T. \& Ratter, J. A. (1995). A study of the origin of central brazilian forests by the analysis of plant species distribution patterns. Edinburg Journal of Botany, 52, 142-194.

Oliveira-Filho, A. T. \& Ratter, J. T. (2002). Vegetation physiognomies and woody flora o the Cerrado biome. In P. S. Oliveira \& R. J. Marquis (Eds.), The Cerrados of Brazil: Ecology and Natural History of a Neotropical Savanna (pp. 91-120). New York, NY: Columbia University Press.

Patterson, B. D. \& Velazco, P. M. (2008). Phylogeny of the rodent genus Isothrix (hystricognathi, echimyidae) and its diversification in Amazonia and the Eastern Andes. Journal of Mammalian Evolution, 15, 181-201.

Por, F. D. (1992) Sooretama: the Atlantic rain forest of Brazil. SPB Academic Publishing, The Hague.

Rambaut, A., Suchard, M. A., Xie, D. \& Drummond, A. J. (2014). Tracer v1.6, available from http://beast.bio.ed.ac.uk/Tracer.

Ramos, A. C. S., Lemos-Filho, J. P. D. \& Lovato, M. B. (2009). Phylogeographical structure of the Neotropical forest tree Hymenaea courbaril (Leguminosae: Caesalpinioideae ) and Its relationship with the vicariant Hymenaea stigonocarpa from Cerrado. Journal of Heredity, 100, 206-216.

Ratter, J. A., Ribeiro, J. F. \& Bridgewater, S. (1997). The Brazilian Cerrado Vegetation and Threats to its Biodiversity. Annals of Botany, 80, 223-230. 
Ribeiro, J. F. \& Walter, B. M. T. (2008). As principais fitofisionomias do bioma Cerrado. In: S. M. Sano, Almeida S. P. \& Ribeiro, J. F. (Eds) Cerrado: Ecologia e flora (151-212). Embrapa Cerrados. Brasília, DF

Rizzini, C. T. (1963). Nota prévia sobre a divisão fitogeográfica do Brasil. Revista Brasileira de Geografia, 1, 1-151.

Silva, J. M. C. (1997). Endemic bird species and conservation in the Cerrado Region, South America. Biodiversity and Conservation, 6, 435-450.

Silva, J. M. C. (1995). Birds of the Cerrado Region, South America. Steenstrupia, 21, 69-92.

Silva, S. M., Moraes-Barros, N., Ribas, C. C., Ferrand, N. \& Morgante, J. S. (2012). Divide to conquer: A complex pattern of biodiversity depicted by vertebrate components in the Brazilian Atlantic Forest. Biological Journal of the Linnean Society, 107, 39-55.

Smith, M. F. \& Patton, J. L. (1993). The diversification of South American murid rodents: evidence from mitochondrial DNA sequence data for the akodontine tribe. Biological Journal of the Linnean Society, 50, 149-177.

Souza-Neto, A. C., Cianciaruso, M. V, \& Collevatti, R. G. (2016). Habitat shifts shaping the diversity of a biodiversity hotspot through time: insights from the phylogenetic structure of Caesalpinioideae in the Brazilian Cerrado. Journal of Biogeography, 43, 340-350.

Teeling, E. C., Scally, M., Kao, D. J., Romagnoli, M. L., Springer, M. S. \& Stanhope, M. J. (2000). Molecular evidence regarding the origin of echolocation and flight in bats. Nature, 403, 188-192.

UNESCO (2003) Subsídios ao zoneamento da APA Gama-Cabeça de Veado e Reserva da Biosfera do Cerrado: caracterização e conflitos socioambientais. Brasília.

Upham, N. S., Ojala-Barbour, R., Brito M. J., Velazco, P. M. \& Patterson, B. D. (2013). Transitions between Andean and Amazon centers of endemism in the radiation of some arboreal rodents. BMC Evolutionary Biology, 13, 1-24.

Upham, N. S. \& Patterson, B. D. (2015). Evolution of caviomorph rodents: a complete phylogeny and timetree for living genera. In A. I. Vassallo \& A. Antenucci (Eds.), Biology of Caviomorph Rodents: Diversity and Evolution (pp. 63-120). Buenos Aires, Argentina. 
Vanzolini, P. E. \& Williams, E. E. (1981). Vanishing refuge: a mechanism for ecogeographic speciation. Papéis Avulsos de Zoologia, 34, 251-255.

Verzi, D. H. (2008). Phylogeny and adaptive diversity of rodents of the family Ctenomyidae (Caviomorpha): delimiting lineages and genera in the fossil record. Journal of Zoology, 274, 386-394.

Verzi, D. H., Olivares, A. I. \& Morgan, C. C. (2013). Phylogeny, evolutionary patterns and timescale of South American octodontoid rodents. The importance of recognising morphological differentiation in the fossil record. Acta Palaeontologica Polonica, 59, 757-769.

Verzi, D. H., Vucetich, M. G. \& Montalvo, C. I. (1995). Un nuevo eumysopinae (Rodentia, Echimyidae) del mioceno tardío de la provincia de La pampa y consideraciones sobre la historia de la subfamilia. Ameghiniana, 32, 191-195.

Voss, R. S. \& Emmons, L. H. (1996). Mammalian Diversity in Neotropical Lowland Rainforests: a Preliminary Assessment. Bulletin of the American Museum of Natural History, 230, 1-115.

Vucetich, G., Vieytes, E. C., Pérez, M. E. \& Carlini, A. A. (2010). The rodents from La Cantera and the early evolution of caviomorphs in South America. In The paleontology of Gran Baranca: Evolution and Environmental Change through the Middle Cenozoic of Patagonia. R. H. Madden, A. A. Carlini, M. G. Vucetich \& R. F. Kay (Eds) (193-205). Cambridge University Press, Cambridge.

Wang, X., Auler, A. S., Edwards, R. L., Cheng, H., Cristalli, P. S., Smart, P. L., Richards, D. A. \& Shen, C. C. (2004). Wet periods in northeastern Brazil over the past $210 \mathrm{kyr}$ linked to distant climate anomalies. Nature, 432, 740-743.

Whittaker, R. (1962). Classification of Natural Communities. Botanical Review, 28, $1-239$.

Yu, Y., Harris, A. J., Blair, C. \& He, X. (2015). RASP (Reconstruct Ancestral State in Phylogenies): a tool for historical biogeography. Molecular Phylogenetics and Evolution, 87, 46-49. 
Appendix 1.1: List of the species used in the present study and GenBank accession numbers of sequences. GenBank accession number of the sequences generated for this study are given in bold. Abbreviation for scientific collection: UNB = Mammal collection of Universidade de

Brasília, Brasília, Brazil; MCNM = Museu de Ciências Naturais, Pontifícia Universidade Católica de Minas Gerais, Brazil; MCNU = Museu de Ciências Naturais, Universidade Luterana do Brasil, Canoas, Rio Grande do Sul, Brazil; MNRJ = Museu Nacional, Universidade Federal do Rio de Janeiro, Rio de Janeiro, Brazil; UFES = Coleção de Mamíferos, Universidade Federal do Espírito Santo, Espírito Santo, Brazil; UFMG = Coleção de Mamíferos do Departamento de Zoologia, Universidade Federal de Minas Gerais, Minas Gerais, Brazil; USNM = National Museum of Natural History, Smithsonian Institution, Washington, DC, USA. Collector responsible for field number listed: H. G. Bergallo (HGB); J. C. Voltolini (NSV); L. Geise (FS); P. H. Asfora (PHA); R. Pardini (B); Y. Yonenaga-Yassuda and V. Fagundes (CIT).

GenBank acession numbers

Species of Phyllomys and species used as outgroups
Catalog number

\begin{tabular}{lllll}
\hline Cyt-b & COI & RAG-1 & GHR & vWF \\
L23339 & - & JX515334 & EU313298 & AJ849307 \\
L23385 & - & JX515335 & EU313322 & AJ849305 \\
L23349 & - & JX515336 & EU3133307 & AJ849308 \\
EU544668 & - & JX515325 & EU313334 & AJ849315 \\
AJ251400 & - & KF590693 & KF590665 & KF590675 \\
EU544663 & - & AF520662 & AY011892 & AJ251140 \\
KJ742659 & - & KJ742627 & KJ742677 & KJ742614
\end{tabular}


Trinomys iheringi

Euryzygomatomys

spinosus

Clyomys laticeps

Octodontomys gliroides

Ctenomys coyhaiquensis

Abracoma bennettii

Chinchilla lanigera

Makalata didelphoides

Echimys chrysurus

Phyllomys centralis sp. n.

UNB3820

MCNM2027

MCNM2153

MCNM2709

$\begin{array}{ll}\text { EU544664 } & - \\ \text { EU544667 } & - \\ \text { AF422918 } & - \\ \text { AF370706 } & - \\ \text { AF119112 } & - \\ \text { AF244387 } & - \\ & \\ \text { AF46760 } & - \\ \text { EU313232 } & \text { JF297658 } \\ \text { KF874584 } & \text { KF874588 } \\ - & - \\ \text { KX852221 } & \text { KX852223 } \\ \text { KF874586 } & \text { KF874590 } \\ \text { KX852222 } & \text { KX852224 } \\ \text { KF874587 } & \text { KF874591 }\end{array}$

$\mathrm{K}$

$\begin{array}{lll}\text { KF590695 } & \text { EU313337 } & \text { KF590677 } \\ \text { JX515327 } & \text { KJ742680 } & \text { AJ849319 } \\ \text { JX515326 } & \text { KJ742679 } & \text { AJ849306 } \\ \text { AF520649 } & \text { KF590663 } & \text { KF590672 } \\ \text { KF590678 } & \text { KF590659 } & \text { KF590666 } \\ \text { FJ855213 } & \text { JN633625 } & \text { AJ251143 } \\ \text { AF332036 } & \text { KF590658 } & \text { AJ238385 } \\ \text { KJ742639 } & \text { KJ742688 } & \text { JF297707 } \\ \text { KX852275 } & \text { KX852248 } & - \\ & & \text { AJ251141 } \\ \text { KX852256 } & \text { KX852229 } & \text { KX852279 } \\ \text { KX852269 } & \text { KX852242 } & \text { KX852280 } \\ - & - & - \\ \text { KX852270 } & \text { KX852243 } & \text { KX852281 }\end{array}$




\begin{tabular}{|c|c|c|c|c|c|c|}
\hline Phyllomys blainvilii & $\begin{array}{l}\text { UFMG3014 } \\
\text { UFMG3017 }\end{array}$ & $\begin{array}{l}\text { EF608180 } \\
\text { EU313239 }\end{array}$ & $\begin{array}{l}\text { JF297686 } \\
\text { JF297684 }\end{array}$ & KX852266 & KX852239 & $\begin{array}{l}\text { JF297735 } \\
\text { JF297733 }\end{array}$ \\
\hline Phyllomys brasiliensis & UFMG 2376 & EF608182 & JF297680 & KX852253 & KX852226 & JF297729 \\
\hline Phyllomys dasythrix & $\begin{array}{l}\text { MCNU828 } \\
\text { MCNU844 }\end{array}$ & $\begin{array}{l}\text { EF608185 } \\
\text { JF297832 }\end{array}$ & $\begin{array}{l}\text { JF297660 } \\
\text { JF297659 }\end{array}$ & $\begin{array}{l}\text { KX852252 } \\
\text { KJ742641 }\end{array}$ & $\begin{array}{l}\text { KX852225 } \\
\text { KJ742689 }\end{array}$ & $\begin{array}{l}\text { JF297709 } \\
\text { JF297708 }\end{array}$ \\
\hline Phyllomys lamarum & $\begin{array}{l}\text { UFES284 } \\
\text { UFMG3016 }\end{array}$ & $\begin{array}{l}\text { JF297816 } \\
\text { EF608181 }\end{array}$ & $\begin{array}{l}\text { JF297682 } \\
\text { JF297681 }\end{array}$ & $\begin{array}{l}\text { KX852267 } \\
\text { KX852264 }\end{array}$ & $\begin{array}{l}\text { KX852240 } \\
\text { KX852237 }\end{array}$ & $\begin{array}{l}\text { JF297731 } \\
\text { JF297730 }\end{array}$ \\
\hline Phyllomys lundi & MNRJ62392 & EF608183 & JF297672 & KX852276 & KX852249 & JF297721 \\
\hline Phyllomys mantiqueirensis & MNRJ62393 & EF608179 & JF297671 & KX852277 & KX852250 & JF297720 \\
\hline Phyllomys nigrispinus & $\begin{array}{l}\text { B723 } \\
\text { NSV160599 }\end{array}$ & $\begin{array}{l}\text { JF297809 } \\
\text { EU313243 }\end{array}$ & $\begin{array}{l}\text { JF297667 } \\
\text { JF297669 }\end{array}$ & $\begin{array}{l}\text { KX852255 } \\
\text { KX852271 }\end{array}$ & $\begin{array}{l}\text { KX852228 } \\
\text { KX852244 }\end{array}$ & $\begin{array}{l}\text { JF297716 } \\
\text { JF297718 }\end{array}$ \\
\hline Phyllomys pattoni & $\begin{array}{l}\text { FS1411 } \\
\text { HGB585 } \\
\text { MNRJ62391 } \\
\text { UFES43 } \\
\text { UFES120 } \\
\text { UFES620 }\end{array}$ & $\begin{array}{l}\text { JF297826 } \\
\text { JF297825 } \\
\text { EF608187 } \\
\text { JF297823 } \\
\text { JF297830 } \\
\text { JF297827 }\end{array}$ & $\begin{array}{l}\text { JF297700 } \\
\text { JF297699 } \\
\text { JF297695 } \\
\text { JF297697 } \\
\text { JF297704 } \\
\text { JF297701 }\end{array}$ & $\begin{array}{l}\text { KX852260 } \\
\text { KX852261 } \\
\text { KJ742606 } \\
\text { KX852278 } \\
\text { KX852274 } \\
\text { KX852268 }\end{array}$ & $\begin{array}{l}\text { KX852233 } \\
\text { KX852234 } \\
\text { KJ742690 } \\
\text { KX852251 } \\
\text { KX852247 } \\
\text { KX852241 }\end{array}$ & $\begin{array}{l}\text { JF297749 } \\
\text { JF297748 } \\
\text { JF297744 } \\
\text { JF297746 } \\
\text { JF297753 } \\
\text { JF297750 }\end{array}$ \\
\hline Phyllomys sulinus & B304 & JF297806 & JF297662 & KX852254 & KX852227 & JF297711 \\
\hline
\end{tabular}




\begin{tabular}{lllllrr} 
& CIT1344 & JF297833 & JF297663 & KX852257 & KX8522230 & JF297712 \\
Phyllomys sp. 1 & UFMG2487 & JF297813 & JF297677 & KX852262 & KX852235 & JF297726 \\
& UFMG2489 & JF297815 & JF297679 & KX852263 & KX852236 & JF297728 \\
Phyllomys sp. 2 & PHA355 & JF297819 & JF297689 & KX852272 & KX852245 & JF297738 \\
& PHA358 & JF297822 & JF297692 & KX852273 & KX852246 & JF297741 \\
Phyllomys sp. 3 & FS643 & JF297835 & JF297673 & KX852258 & KX852231 & JF297722 \\
& FS1230 & EF608184 & JF297675 & KX852259 & KX852232 & JF297724 \\
\hline
\end{tabular}


Appendix 2.1: Thermocycling conditions for amplification of each molecular marker.

cytb: initial denaturation at $94{ }^{\circ} \mathrm{C}-5 \mathrm{~min} ; 39$ cycles [denaturation at $94{ }^{\circ} \mathrm{C}-30 \mathrm{~s}$, annealing at $48{ }^{\circ} \mathrm{C}-45 \mathrm{~s}$ and extension at $\left.72{ }^{\circ} \mathrm{C}-45 \mathrm{~s}\right]$ and final extension at $72{ }^{\circ} \mathrm{C}$ 5 min.

COI: initial denaturation at $94{ }^{\circ} \mathrm{C}-5 \mathrm{~min} ; 40$ cycles [denaturation at $94{ }^{\circ} \mathrm{C}-30 \mathrm{~s}$, annealing at $44{ }^{\circ} \mathrm{C}-45 \mathrm{~s}$ and extension at $72{ }^{\circ} \mathrm{C}-45 \mathrm{~s}$ ] and final extension at $72{ }^{\circ} \mathrm{C}$ $5 \min$

$v W F(1)^{*}$ primers V10 and W13: initial denaturation at $95{ }^{\circ} \mathrm{C}-5 \mathrm{~min} ; 5$ cycles

[denaturation at $95{ }^{\circ} \mathrm{C}-1 \mathrm{~min}$, annealing at $61{ }^{\circ} \mathrm{C}-1 \mathrm{~min}$ and extension at $72{ }^{\circ} \mathrm{C}-1$ min] four blocks of 5 cycles with the same denaturation and extension conditions of the previous cycle, but with annealing temperature $2{ }^{\circ} \mathrm{C}$ below $\left(59,57,55\right.$ e $53{ }^{\circ} \mathrm{C}$; one block with 10 cycles with denaturation and extension conditions of the previous cycle and annealing at $53{ }^{\circ} \mathrm{C}$; final extension at $72{ }^{\circ} \mathrm{C}-10 \mathrm{~min}$. $v W F(2)^{*}$ primes $\mathrm{V} 2$ and $\mathrm{W} 1$ : initial denaturation at $94{ }^{\circ} \mathrm{C}-5 \mathrm{~min} ; 39$ cycles [denaturation at $94{ }^{\circ} \mathrm{C}-1 \mathrm{~min}$, annealing at $58{ }^{\circ} \mathrm{C}-1 \mathrm{~min}$ and extension at $72{ }^{\circ} \mathrm{C}-1$ min]; final extension at $72{ }^{\circ} \mathrm{C}-10 \mathrm{~min}$.

GHR: initial denaturation at $94{ }^{\circ} \mathrm{C}-5 \mathrm{~min} ; 36$ cycles [denaturation at $94{ }^{\circ} \mathrm{C}-30 \mathrm{~s}$, anneling at $55{ }^{\circ} \mathrm{C}-1 \mathrm{~min}$ and extension at $\left.72{ }^{\circ} \mathrm{C}-30 \mathrm{~s}\right]$; and final extension at $72{ }^{\circ} \mathrm{C}-$ $5 \mathrm{~min}$.

$R A G 1$ : initial denaturation at $94{ }^{\circ} \mathrm{C}-5 \mathrm{~min} ; 30$ cycles [denaturation at $94{ }^{\circ} \mathrm{C}-30 \mathrm{~s}$, annealing at $60{ }^{\circ} \mathrm{C}-1 \mathrm{~min}$ and axtension at $\left.72{ }^{\circ} \mathrm{C}-30 \mathrm{~s}\right]$; and final extention at $72{ }^{\circ} \mathrm{C}$ -5 min.

Note: $* W F(1)$ and $v W F(2)$ represent independent amplification processes with sequences joined after sequencing reaction. 
Appendix 3.1: Models of evolution estimated in jModelTest 2.1.7 (Darriba et al. 2012), allowing three substitutions schemes and gamma parameter estimate using Bayesian Information Criterion.

\begin{tabular}{lcccccc}
\hline \multirow{2}{*}{ Type of analysis } & \multirow{2}{*}{ OTUs } & \multicolumn{5}{c}{ Molecular marker } \\
\cline { 3 - 7 } MrBayes phylogeny & 30 & GTR+G & GTR+G & K80+G & HKY+G & K80+G \\
BEAST dating & 44 & GTR+G & & K80+G & GTR+G & K80+G \\
\hline
\end{tabular}

Reference:

Darriba, D., Taboada, G. L., Doallo, R. \& Posada, D. (2012) jModelTest 2: more models, new heuristics and parallel computing. Nature Methods, 9, 772-772. 
Appendix 4.1: Map showing occurrence localities used to define the geographic distribution for each Phyllomys species. In brown the limits of Caatinga; in beige the limits of Cerrado; in light gray the limits of Atlantic Forest. Numbers indicate localities with information presented in Appendix 5.1.

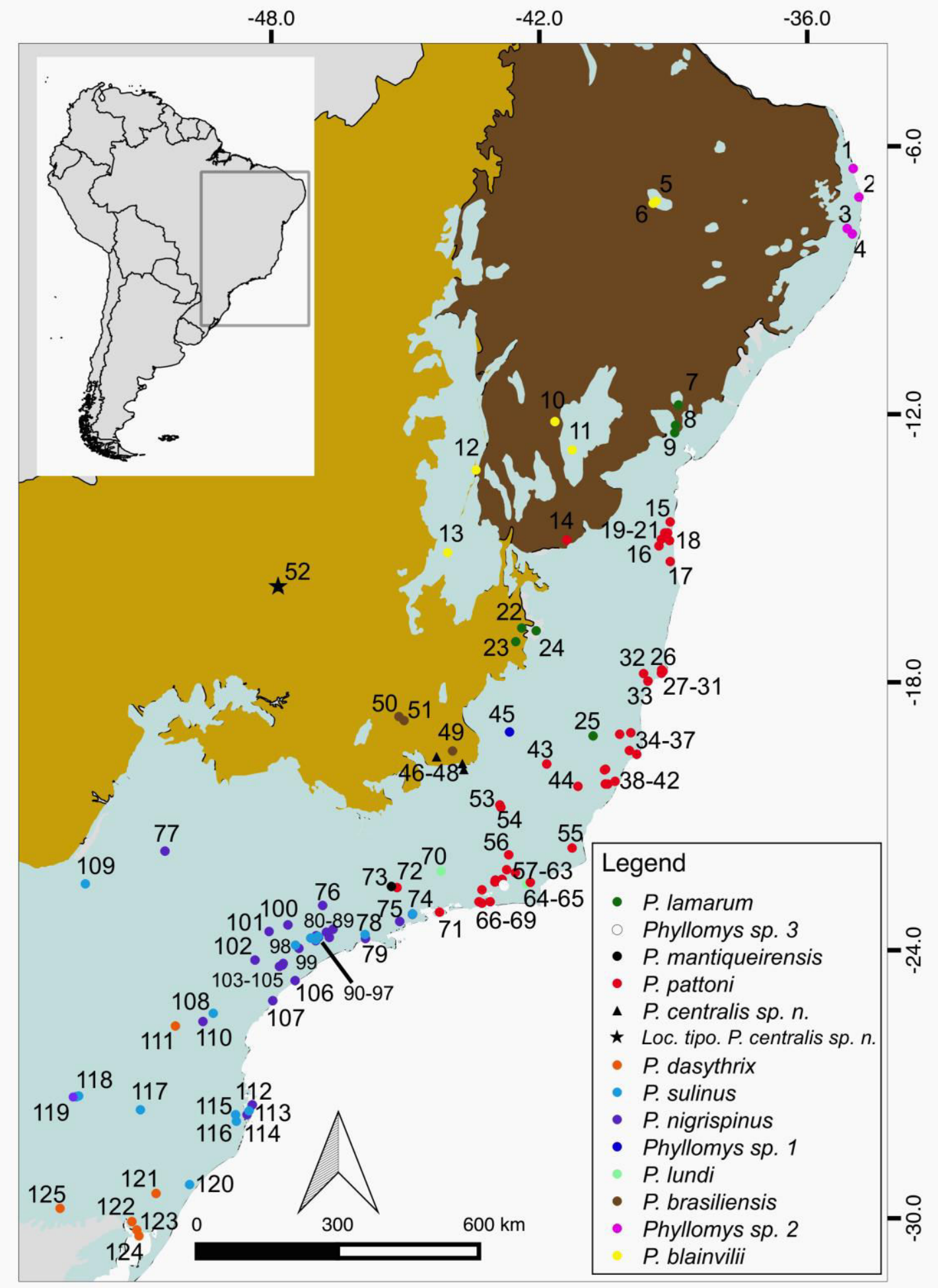


Appendix 5.1: Table showing specimens catalog numbers, localities, and coordinates (decimal degrees) used to contruct the map of distribution (Appendix 4.1). Map code denotes localities of the distribution map. Acronyms of the intitutions housing the exemplars are given in Appendix 1.1. Specimens identified with one asterisk indicate DNA sequenced in present study; two astriks indicate DNA obtained from dry skins (old DNA).

\begin{tabular}{|c|c|c|c|c|c|c|}
\hline $\begin{array}{l}\text { Sampe catalog } \\
\text { number }\end{array}$ & Map code & Species & Locality & State & Long. & Lat. \\
\hline UFPB 5690 & 1 & Phyllomys sp. 2 & $\begin{array}{l}\text { Floresta da Lyondel Chemical Company - } \\
\text { Mataraca }\end{array}$ & PB & -34.9667 & -6.5 \\
\hline UFPB 5922 & 2 & Phyllomys sp. 2 & $\begin{array}{l}\text { Campus I - Universidade Federal da Paraíba - } \\
\text { João Pessoa }\end{array}$ & PB & -34.8397 & -7.1392 \\
\hline MNRJ 1350 & 5 & P. blainvilii & Crato & $\mathrm{CE}$ & -39.3833 & -7.2333 \\
\hline MVZ 197568* & 6 & P. blainvilii & Chapada do Araripe - $7 \mathrm{~km} \mathrm{SW}$ Crato & $\mathrm{CE}$ & -39.4508 & -7.2775 \\
\hline PHA 358* & 3 & Phyllomys sp. 2 & $\begin{array}{l}\text { CIMNC (Campo de Instrução Marechal } \\
\text { Newton Cavalcanti) - Paudalho } \\
\text { Granja Maturi - Condomío Chã de Peroba - }\end{array}$ & PE & -35.1019 & -7.8439 \\
\hline DAM 175 & 4 & Phyllomys sp. 2 & $\begin{array}{l}\text { Granja Maturi - Condomío Chã de Peroba - } \\
\text { km } 6 \text { da estrada de Aldeia - Aldeia - } \\
\text { Camaragibe }\end{array}$ & PE & -34.9878 & -7.9636 \\
\hline DAM 179 & 4 & Phyllomys sp. 2 & $\begin{array}{l}\text { Granja Maturi - Condomínio Chã de Peroba - } \\
\text { km } 6 \text { da estrada de Aldeia - Aldeia - } \\
\text { Camaragibe }\end{array}$ & PE & -34.9878 & -7.9636 \\
\hline PHA $355^{*}$ & 4 & Phyllomys sp. 2 & $\begin{array}{l}\text { Granja Maturi - Condomío Chã de Peroba - } \\
\text { km } 6 \text { da estrada de Aldeia - Aldeia - } \\
\text { Camaragibe }\end{array}$ & PE & -34.9878 & -7.9636 \\
\hline PHA 356 & 4 & Phyllomys sp. 2 & $\begin{array}{l}\text { Granja Maturi - Condomío Chã de Peroba - } \\
\text { km } 6 \text { da estrada de Aldeia - Aldeia - } \\
\text { Camaragibe }\end{array}$ & PE & -34.9878 & -7.9636 \\
\hline PHA 357 & 4 & Phyllomys sp. 2 & $\begin{array}{l}\text { Granja Maturi - Condomío Chã de Peroba - } \\
\text { km } 6 \text { da estrada de Aldeia - Aldeia - } \\
\text { Camaragibe }\end{array}$ & PE & -34.9878 & -7.9636 \\
\hline BMNH 3.9.5.96 & 7 & P. lamarum & Lamarão - ca. 70 milhas NW Salvador & BA & -38.8817 & -11.7936 \\
\hline
\end{tabular}




\begin{tabular}{|c|c|c|c|c|c|c|}
\hline UZMC 1282 & 7 & P. lamarum & Lamarão - ca. 70 milhas NW Salvador & BA & -38.8817 & -11.7936 \\
\hline MNRJ 21626 & 10 & P. blainvilii & Várzea da Canabrava- Seabra & BA & -41.65 & -12.1667 \\
\hline MNRJ 11260 & 8 & P. lamarum & 9 km SE Feira de Santana & BA & -38.95 & -12.25 \\
\hline MNRJ 11259 & 9 & P. lamarum & São Gonçalo - 30 km SW Feira de Santana & BA & -38.9667 & -12.4167 \\
\hline UFMG 3017* & 11 & P. blainvilii & Fazenda Santa Rita - 8 km E Andaraí & $\mathrm{BA}$ & -41.2614 & -12.8017 \\
\hline MNRJ 4125 & 12 & P. blainvilii & Rio São Francisco - Bom Jesus da Lapa & BA & -43.4167 & -13.25 \\
\hline RM 238 & 15 & P. pattoni & $\begin{array}{l}\text { Parque Estadual Serra do Conduru (Ilhéus- } \\
\text { Uruçuca e Itacaré } \square \text { ) }\end{array}$ & BA & -39.0682 & -14.4125 \\
\hline MNRJ 21517 & 19 & P. pattoni & Aritaguaİ $\square$ - Urucutuca - IlhÃ@us & BA & -39.1253 & -14.6578 \\
\hline MNRJ 11253 & 20 & P. pattoni & Fazenda Almada - Ilhéus & $\mathrm{BA}$ & -39.1903 & -14.66 \\
\hline MNRJ 33515 & 21 & P. pattoni & Itabuna & $\mathrm{BA}$ & -39.2667 & -14.8 \\
\hline MNRJ 22264 & 14 & P. pattoni & São Felipe & BA & -41.3833 & -14.8167 \\
\hline MNRJ 22265 & 14 & P. pattoni & São Felipe & BA & -41.3833 & -14.8167 \\
\hline MNRJ 10452 & 18 & P. pattoni & Fazenda Pirataquicê - Ilhéu & BA & -39.0833 & -14.83 \\
\hline MNRJ 11254 & 16 & P. pattoni & Mata Fortuna - Itabuna & BA & -39.32 & -14.95 \\
\hline CIT 808 & 17 & P. pattoni & Una -Ilhéus & BA & -39.0667 & -15.3 \\
\hline MNRJ 62391* & 26 & P. pattoni & Mangue do Caritoti - Caravelas & BA & -39.2597 & -17.725 \\
\hline MVZ 197621 & 26 & P. pattoni & Mangue do Caritoti - Caravelas & BA & -39.2597 & -17.725 \\
\hline
\end{tabular}




\begin{tabular}{|c|c|c|c|c|c|c|}
\hline SNM 5839 & 26 & P. pattoni & Mangue do Caritoti - Caravelas & BA & -39.2597 & -17.725 \\
\hline UFES 96 & 27 & P. pattoni & Chácara do Lulu - Caravelas & BA & -39.2561 & -17.7278 \\
\hline UFES 122 & 27 & P. pattoni & Chácara do Lulu - Caravelas & BA & -39.2561 & -17.7278 \\
\hline UFES 98 & 28 & P. pattoni & $\begin{array}{l}\text { Fazenda Espada Ilha - Ilha da Cassumba- } \\
\text { Caravelas }\end{array}$ & BA & -39.255 & -17.7533 \\
\hline UFES $120 *$ & 29 & P. pattoni & Ilha Salina - Caravelas & BA & -39.2281 & -17.7581 \\
\hline UFES 121 & 30 & P. pattoni & $\begin{array}{l}\text { Fazenda Monte Castelo - Ilha da Cassumba - } \\
\text { Caravelas }\end{array}$ & BA & -39.2639 & -17.7944 \\
\hline MZUSP 31953 & 31 & P. pattoni & $\begin{array}{l}\text { Fazenda Monte Castelo - Ilha da Cassumba - } 7 \\
\text { km SW Caravelas }\end{array}$ & BA & -39.2636 & -17.8017 \\
\hline YL 199 & 31 & P. pattoni & $\begin{array}{l}\text { Fazenda Monte Castelo - Ilha da Cassumba - } 7 \\
\text { km SW Caravelas }\end{array}$ & BA & -39.2636 & -17.8017 \\
\hline YL 200 & 31 & P. pattoni & $\begin{array}{l}\text { Fazenda Monte Castelo - Ilha da Cassumba - } 7 \\
\text { km SW Caravelas }\end{array}$ & BA & -39.2636 & -17.8017 \\
\hline YL 201 & 31 & P. pattoni & $\begin{array}{l}\text { Fazenda Monte Castelo - Ilha da Cassumba - } 7 \\
\text { km SW Caravelas }\end{array}$ & BA & -39.2636 & -17.8017 \\
\hline SLF 9 & 32 & P. pattoni & Fazenda Elma - Nova Viçosa & BA & -39.5647 & -17.9756 \\
\hline UFES 97 & 32 & P. pattoni & Fazenda Elma - Nova Viçosa & BA & -39.5647 & -17.9756 \\
\hline UFES 99 & 33 & P. pattoni & Fazenda João Guarda - Nova Viçosa & BA & -39.5672 & -17.9789 \\
\hline UNB $3820^{*}$ & 52 & P. centralis sp. $\mathrm{n}$. & Fazenda Água Limpa, Brasília & DF & -47.829 & -15.8622 \\
\hline MNRJ 43810* & 13 & P. blainvilii & Mocambinho -Jaíba & MG & -44.05 & -15.1 \\
\hline MCNM 2704 & 22 & P. lamarum & UHE Irapé & MG & -42.6717 & -16.7886 \\
\hline MCNM 2705 & 22 & P. lamarum & UHE Irapé & MG & -42.6717 & -16.7886 \\
\hline MCNM 2706 & 22 & P. lamarum & UHE Irapé & MG & -42.6717 & -16.7886 \\
\hline
\end{tabular}




\begin{tabular}{|c|c|c|c|c|c|c|}
\hline MCNM 2707 & 22 & P. lamarum & UHE Irapé & MG & -42.6717 & -16.7886 \\
\hline MCNM $2275^{* *}$ & 24 & P. lamarum & Araçuaí & MG & -42.07 & -16.85 \\
\hline UFMG $3016^{*}$ & 23 & P. lamarum & $\begin{array}{l}\text { Estação Ecológica de Aracuã - } 17 \text { km N } \\
\text { Turmalina }\end{array}$ & MG & -42.7667 & -17.1333 \\
\hline AP $48^{*}$ & 50 & P. brasiliensis & Fazenda Santa Cruz - Felixlândia & MG & -45.1428 & -18.7706 \\
\hline MCNM 1733 & 51 & P. brasiliensis & UHE Retiro Baixo - Pompeu & MG & -45.0267 & -18.8603 \\
\hline MCNM 1734* & 51 & P. brasiliensis & UHE Retiro Baixo - Pompeu & MG & -45.0267 & -18.8603 \\
\hline UFMG 2486 & 45 & Phyllomys sp. 1 & Usina Hidrelétrica de Braúnas & MG & -42.6653 & -19.1153 \\
\hline UFMG $2487^{*}$ & 45 & Phyllomys sp. 1 & Usina Hidrelétrica de Braúnas & MG & -42.6653 & -19.1153 \\
\hline UFMG 2488 & 45 & Phyllomys sp. 1 & Usina Hidrelétrica de Braúnas & MG & -42.6653 & -19.1153 \\
\hline UFMG $2489^{*}$ & 45 & Phyllomys sp. 1 & Usina Hidrelétrica de Braúnas & MG & -42.6653 & -19.1153 \\
\hline UZMC 81 & 49 & P. brasiliensis & Sumidouro - ca. 12 km NW Lagoa Santa & MG & -43.9411 & -19.5411 \\
\hline MCNM $2153^{* *}$ & 46 & P. centralis sp. $\mathrm{n}$. & Belo Horizonte & MG & -43.9128 & -19.8222 \\
\hline GABF 97P & 43 & P. pattoni & Fazenda Montes Claros - Caratinga & MG & -41.8333 & -19.8333 \\
\hline MCNM 2027* & 47 & P. centralis sp. $\mathrm{n}$. & Santa Bárbara & MG & -43.415 & -19.9589 \\
\hline MCNM 2709* & 48 & P. centralis sp. $\mathrm{n}$. & Catas Altas & MG & -43.3981 & -20.0742 \\
\hline UFV 379 & 53 & P. pattoni & Silvicultura - Viçosa & MG & -42.8833 & -20.75 \\
\hline UFV 385 & 54 & P. pattoni & Mata Paraíso - Viçosa & MG & -42.8589 & -20.805 \\
\hline UFV 696 & 54 & P. pattoni & Mata Paraíso - Viçosa & MG & -42.8589 & -20.805 \\
\hline
\end{tabular}




\begin{tabular}{|c|c|c|c|c|c|c|}
\hline MNRJ 4077 & 56 & P. pattoni & Fazenda São Geraldo - Além Paraíba & MG & -42.6833 & -21.8667 \\
\hline MNRJ 62392* & 70 & P. lundi & Fazenda do Bené - 4 km SE Passa Vinte & MG & -44.2 & -22.2333 \\
\hline MNRJ 62393* & 73 & P. mantiqueirensis & Fazenda da Onça - 13 km SW Delfim Moreira & MG & -45.3333 & -22.6 \\
\hline UFMG 226 & 34 & P. pattoni & Fazenda Santa Terezinha- 33 km NE Linhares & ES & -39.95 & -19.1333 \\
\hline MNRJ 8276 & 35 & P. pattoni & Rio São João & ES & -40.2 & -19.1667 \\
\hline UFES $284^{*}$ & 25 & P. lamarum & Pancas & ES & -40.7953 & -19.2044 \\
\hline UFES 246 & 36 & P. pattoni & Fazenda Sapucaia - Bananal do - Linhares & ES & -39.9816 & -19.5313 \\
\hline MBML 1856 & 37 & P. pattoni & Povoação - Linhares & ES & -39.8167 & -19.6167 \\
\hline UFES 28 & 38 & P. pattoni & Parque Estadual da Fonte Grande - Vitória & ES & -40.35 & -20.35 \\
\hline UFES 29 & 38 & P. pattoni & Parque Estadual da Fonte Grande - Vitória & ES & -40.35 & -20.35 \\
\hline UFES 30 & 38 & P. pattoni & Parque Estadual da Fonte Grande - Vitória & ES & -40.35 & -20.35 \\
\hline UFES 31 & 38 & P. pattoni & Parque Estadual da Fonte Grande - Vitória & ES & -40.35 & -20.35 \\
\hline UFES 32 & 38 & P. pattoni & Parque Estadual da Fonte Grande - Vitória & ES & -40.35 & -20.35 \\
\hline UFES 33 & 38 & P. pattoni & Parque Estadual da Fonte Grande - Vitória & ES & -40.35 & -20.35 \\
\hline UFES 42 & 38 & P. pattoni & Parque Estadual da Fonte Grande - Vitória & ES & -40.35 & -20.35 \\
\hline UFES $43 *$ & 38 & P. pattoni & Parque Estadual da Fonte Grande - Vitória & ES & -40.35 & -20.35 \\
\hline UFES 908 & 38 & P. pattoni & Parque Estadual da Fonte Grande - Vitória & ES & -40.35 & -20.35 \\
\hline MBML 2011 & 39 & P. pattoni & Estação Biológica Santa Lúcia - Santa Teresa & ES & -40.5394 & -19.965 \\
\hline
\end{tabular}




\begin{tabular}{|c|c|c|c|c|c|c|}
\hline MBML 2032 & 39 & P. pattoni & Estação Biológica Santa Lúcia - Santa Teresa & ES & -40.5394 & -19.965 \\
\hline MBML 2047 & 39 & P. pattoni & Estação Biológica Santa Lúcia - Santa Teresa & ES & -40.5394 & -19.965 \\
\hline UFES 909 & 39 & P. pattoni & Estação Biológica Santa Lúcia - Santa Teresa & ES & -40.5394 & -19.965 \\
\hline UFES 910 & 39 & P. pattoni & Estação Biológica Santa Lúcia - Santa Teresa & ES & -40.5394 & -19.965 \\
\hline UFES 911 & 39 & P. pattoni & Estação Biológica Santa Lúcia - Santa Teresa & ES & -40.5394 & -19.965 \\
\hline MBML 2203 & 40 & P. pattoni & $\begin{array}{l}\text { Manquezal de Vitória, próximo ao Bairro } \\
\text { Maria Ortiz }\end{array}$ & ES & -40.3028 & -20.221 \\
\hline UFES 439 & 41 & P. pattoni & $\begin{array}{l}\text { Reserva Biológica de Duas Bocas- Alto } \\
\text { Alegre- Cariacica }\end{array}$ & ES & -40.5219 & -20.2811 \\
\hline UFES 440 & 41 & P. pattoni & $\begin{array}{l}\text { Reserva Biológica de Duas Bocas- Alto } \\
\text { Alegre- Cariacica }\end{array}$ & ES & -40.5219 & -20.2811 \\
\hline UFES $620 *$ & 41 & P. pattoni & $\begin{array}{l}\text { Reserva Biológica de Duas Bocas- Alto } \\
\text { Alegre- Cariacica }\end{array}$ & ES & -40.5219 & -20.2811 \\
\hline UFES 621 & 41 & P. pattoni & $\begin{array}{l}\text { Reserva Biológica de Duas Bocas- Alto } \\
\text { Alegre- Cariacica }\end{array}$ & ES & -40.5219 & -20.2811 \\
\hline UFES 622 & 41 & P. pattoni & $\begin{array}{l}\text { Reserva Biológica de Duas Bocas- Alto } \\
\text { Alegre- Cariacica }\end{array}$ & ES & -40.5219 & -20.2811 \\
\hline UFES 623 & 41 & P. pattoni & $\begin{array}{l}\text { Reserva Biológica de Duas Bocas- Alto } \\
\text { Alegre- Cariacica }\end{array}$ & ES & -40.5219 & -20.2811 \\
\hline UFES 624 & 41 & P. pattoni & $\begin{array}{l}\text { Reserva Biológica de Duas Bocas- Alto } \\
\text { Alegre- Cariacica }\end{array}$ & ES & -40.5219 & -20.2811 \\
\hline MBML 226 & 42 & P. pattoni & $\begin{array}{l}\text { Reserva Biológica de Duas Bocas- Alto } \\
\text { Alegre- Cariacica }\end{array}$ & ES & -40.4667 & -20.2833 \\
\hline UFPB 346 & 44 & P. pattoni & $\begin{array}{l}\text { Hotel Fazenda Monte Verde- } 24 \mathrm{~km} \mathrm{SE} \\
\text { Venda Nova do Imigrante }\end{array}$ & ES & -41.1333 & -20.3333 \\
\hline MCNM $2156^{* *}$ & 64 & P. pattoni & Campos dos Goytacazes & RJ & -41.2642 & -21.7144 \\
\hline MVZ 183139 & 57 & P. pattoni & $\begin{array}{l}\text { Fazenda São João da Serra- } 6 \text { km E e 9-2 km } \\
\text { N Bonsucesso- Sumidouro }\end{array}$ & RJ & -42.73 & -22.2 \\
\hline MNRJ 31564 & 58 & P. pattoni & Nova Friburgo & RJ & -42.5333 & -22.2667 \\
\hline
\end{tabular}




\begin{tabular}{|c|c|c|c|c|c|c|}
\hline MNRJ 31522 & 59 & P. pattoni & Fazenda Alpina - Tersópolis & RJ & -42.8333 & -22.4167 \\
\hline MNRJ 1933 & 59 & P. pattoni & Fazenda Alpina - Tersópolis & RJ & -42.8333 & -22.4167 \\
\hline MNRJ 6237 & 60 & P. pattoni & Fazenda Alpina - Tersópolis & RJ & -42.9833 & -22.4333 \\
\hline MNRJ 6440 & 60 & P. pattoni & Fazenda Alpina - Tersópolis & RJ & -42.9833 & -22.4333 \\
\hline MNRJ 2232 & 60 & P. pattoni & Fazenda Alpina - Tersópolis & RJ & -42.9833 & -22.4333 \\
\hline DL 19 & 61 & P. pattoni & Garrafão & RJ & -42.9933 & -22.4744 \\
\hline DL 20 & 61 & P. pattoni & Garrafão & RJ & -42.9933 & -22.4744 \\
\hline DL 21 & 61 & P. pattoni & Garrafão & RJ & -42.9933 & -22.4744 \\
\hline FS $11-52$ & 62 & P. pattoni & Fazenda Rosimery - Cachoeiras de Macacu & RJ & -42.85 & -22.4833 \\
\hline FS $14-11 *$ & 62 & P. pattoni & Fazenda Rosimery - Cachoeiras de Macacu & RJ & -42.85 & -22.4833 \\
\hline RBPDA 2228 & 65 & P. lundi & $\begin{array}{l}\text { Reserva Biológica poço das Antas - Silva } \\
\text { Jardim }\end{array}$ & RJ & -42.2833 & -22.5167 \\
\hline FS 6-43* & 63 & Phyllomys sp. 3 & FS6 - Cachoeiras de Macacu & RJ & -42.8 & -22.5333 \\
\hline HGB $585^{*}$ & 71 & P. pattoni & Caxadaço- Ilha Grande - Angra dos Reis & RJ & -44.2333 & -23.15 \\
\hline IG 34 & 71 & P. pattoni & Caxadaço- Ilha Grande - Angra dos Reis & RJ & -44.2333 & -23.15 \\
\hline MNRJ 31562 & 71 & P. pattoni & Caxadaço- Ilha Grande - Angra dos Reis & RJ & -44.2333 & -23.15 \\
\hline MZUSP 26718 & 71 & P. pattoni & Caxadaço- Ilha Grande - Angra dos Reis & RJ & -44.2333 & -23.15 \\
\hline BOCA 299 & 75 & P. nigrispinus & $\begin{array}{l}\text { Parque Nacional da Serra da Bocaina - RJ- } \\
\text { 165- Paraty- Área } 1\end{array}$ & RJ & -44.8372 & -23.1897 \\
\hline BOCA 364 & 75 & P. nigrispinus & $\begin{array}{l}\text { Parque Nacional da Serra da Bocaina - RJ- } \\
\text { 165- Paraty- Área } 1\end{array}$ & RJ & -44.8372 & -23.1897 \\
\hline
\end{tabular}




\begin{tabular}{|c|c|c|c|c|c|c|}
\hline BOCA 291 & 75 & P. nigrispinus & $\begin{array}{l}\text { Parque Nacional da Serra da Bocaina - RJ- } \\
\text { 165- Paraty- Área } 1\end{array}$ & RJ & -44.8372 & -23.1897 \\
\hline MZUSP 3738 & 77 & P. nigrispinus & Vanuire & SP & -50.3833 & -21.7833 \\
\hline MZUSP 8885 & 109 & P. sulinus & Teodoro Sampaio & SP & -52.1667 & -22.5167 \\
\hline MZUSP 138 & 72 & P. pattoni & Piquete & SP & -45.1833 & -22.6 \\
\hline MZUSP 664 & 76 & P. nigrispinus & Itatiba & SP & -46.85 & -23 \\
\hline NSV 160599 & 74 & P. sulinus & $\begin{array}{l}\text { Parque Estadual da Serra do Mar - Núcleo } \\
\text { Santa Virgínia - } 10 \mathrm{~km} \text { NW Ubatuba }\end{array}$ & SP & -45.125 & -23.3583 \\
\hline NMW B 918 & 100 & P. nigrispinus & $\begin{array}{l}\text { Floresta Nacional de Ipanema - } 20 \mathrm{~km} \mathrm{NW} \\
\text { Sorocaba }\end{array}$ & SP & -47.6281 & -23.4353 \\
\hline MZUSP 1954 & 80 & P. nigrispinus & São Paulo & SP & -46.6167 & -23.5333 \\
\hline MZUSP 175 & 101 & P. nigrispinus & Itapetininga & SP & -48.05 & -23.5833 \\
\hline MZUSP sp. 26652 & 81 & P. nigrispinus & Taboão da Serra & SP & -46.7667 & -23.6 \\
\hline USNM 460569 & 78 & P. sulinus & Estação Biológica de Boracéia, Salesópolis & SP & -45.9 & -23.65 \\
\hline B 48 & 82 & P. nigrispinus & $\begin{array}{l}\text { Sítio Ruth - Reserva Florestal do Morro } \\
\text { Grande - Cotia }\end{array}$ & SP & -46.995 & -23.6788 \\
\hline SS $87 * *$ & 83 & P. nigrispinus & $\begin{array}{l}\text { Localidade B - Reserva Florestal do Morro } \\
\text { Grande- Cotia }\end{array}$ & SP & -46.9567 & -23.6958 \\
\hline В 554 & 84 & P. sulinus & $\begin{array}{l}\text { Sítion Psicótica - Reserva Florestal do Morro } \\
\text { Grande - Cotia }\end{array}$ & SP & -46.9548 & -23.696 \\
\hline В 539 & 85 & P. nigrispinus & $\begin{array}{l}\text { Sítio Caucaia - Reserva Florestal do Morro } \\
\text { Grande- Cotia }\end{array}$ & SP & -46.9949 & -23.6966 \\
\hline SS $51 * *$ & 86 & P. nigrispinus & $\begin{array}{l}\text { Localidade C - Reserva Florestal do Morro } \\
\text { Grande- Cotia }\end{array}$ & SP & -46.9456 & -23.715 \\
\hline MZUSP 10311 & 87 & P. nigrispinus & Interlagos & SP & -46.7 & -23.7167 \\
\hline BS $1066 * *$ & 88 & P. sulinus & Lacerda - Ibiúna & $\mathrm{SP}$ & -47.1178 & -23.7303 \\
\hline
\end{tabular}




\begin{tabular}{|c|c|c|c|c|c|c|}
\hline BS $307^{* *}$ & 89 & P. sulinus & Pedroso - Ibiúna & SP & -47.0744 & -23.7358 \\
\hline UFMG 948 & 79 & P. nigrispinus & Rio Guaratuba- Bertioga & SP & -45.8911 & -23.7408 \\
\hline B 50 & 90 & P. nigrispinus & $\begin{array}{l}\text { SÃtio Cacìßador - Reserva Florestal do Morro } \\
\text { Grande - Cotia }\end{array}$ & SP & -47.0014 & -23.7438 \\
\hline В 374 & 90 & P. nigrispinus & $\begin{array}{l}\text { Sítion Dilúvio - Reserva Florestal do Morro } \\
\text { Grande - Cotia }\end{array}$ & SP & -46.9971 & -23.7448 \\
\hline B $304 *$ & 92 & P. sulinus & $\begin{array}{l}\text { SÃtio Pseudoİ } \square \text { pode - Reserva Florestal do } \\
\text { Morro Grande - Cotia }\end{array}$ & SP & -47.0027 & -23.7471 \\
\hline В 641 & 92 & P. sulinus & $\begin{array}{l}\text { Sítiio Pseudópode - Reserva Florestal do } \\
\text { Morro Grande - Cotia }\end{array}$ & SP & -47.0027 & -23.7471 \\
\hline BS 921 & 93 & P. nigrispinus & Quilombo - Cotia & SP & -47.0047 & -23.7558 \\
\hline BS $814 * *$ & 93 & P. sulinus & Quilombo - Cotia & SP & -47.0047 & -23.7558 \\
\hline B 435 & 94 & P. nigrispinus & $\begin{array}{l}\text { Sítio Catedral - Reserva Florestal do Morro } \\
\text { Grande - Cotia }\end{array}$ & SP & -46.9988 & -23.763 \\
\hline В 697 & 94 & P. nigrispinus & $\begin{array}{l}\text { Sítio Catedral - Reserva Florestal do Morro } \\
\text { Grande - Cotia }\end{array}$ & SP & -46.9988 & -23.763 \\
\hline B 407 & 95 & P. sulinus & $\begin{array}{l}\text { Sítio Maritaca - Reserva Florestal do Morro } \\
\text { Grande - Cotia }\end{array}$ & SP & -47.0048 & -23.7699 \\
\hline B $723 *$ & 96 & P. nigrispinus & $\begin{array}{l}\text { SÃtio Palmito - Reserva Florestal do Morro } \\
\text { Grande - Cotia }\end{array}$ & SP & -47.0011 & -23.7711 \\
\hline В 733 & 97 & P. nigrispinus & $\begin{array}{l}\text { Sítio Pexe - Reserva Florestal do Morro } \\
\text { Grande - Cotia }\end{array}$ & SP & -47.0063 & -23.7907 \\
\hline AB 490 & 98 & P. sulinus & Sítio Baleia - Piedade & SP & -47.4598 & -23.889 \\
\hline AB 527 & 99 & P. nigrispinus & Sítion Juparí - Piedade & SP & -47.3826 & -23.9604 \\
\hline RG 1969 & 102 & P. nigrispinus & Sítio Moacir - Ribeirão Grande & SP & -48.3666 & -24.2235 \\
\hline FMNH 94358 & 103 & P. nigrispinus & Primeiro Morro & SP & -47.7333 & -24.3 \\
\hline
\end{tabular}




\begin{tabular}{|c|c|c|c|c|c|c|}
\hline FMNH 94359 & 104 & P. nigrispinus & Ribeirão Fundo & SP & -47.75 & -24.3333 \\
\hline FMNH 93045 & 105 & P. nigrispinus & Barra do Rio Juquiá & SP & -47.8167 & -24.3667 \\
\hline MZUSP 25862 & 106 & P. nigrispinus & Barra de Icapara & SP & -47.4667 & -24.6833 \\
\hline MUSP 27755 & 107 & P. nigrispinus & Ilha do Cardoso - Cananéia & SP & -47.9667 & -25.1333 \\
\hline MHNCI 2599 & 108 & P. sulinus & Parque Barigui - Bairro Mercês- Curitiba & PR & -49.3008 & -25.4156 \\
\hline MZUSP 6431 & 110 & P. nigrispinus & Guajuvira & PR & -49.5333 & -25.6 \\
\hline BMNH 0.6.29.20 & 111 & P. dasythrix & Palmira & PR & -50.15 & -25.7 \\
\hline FURB 6257 & 119 & P. nigrispinus & Usina Hidrelétrica de Itá - Itá & $\mathrm{SC}$ & -52.3691 & -27.2815 \\
\hline FURB 5193 & 119 & P. nigrispinus & Usina Hidrelétrica de Itá - Itá & $\mathrm{SC}$ & -52.3691 & -27.2815 \\
\hline FURB 5239 & 119 & P. nigrispinus & Usina Hidrelétrica de Itá - Itá & $\mathrm{SC}$ & -52.3691 & -27.2815 \\
\hline FURB 5521 & 119 & P. nigrispinus & Usina Hidrelétrica de Itá - Itá & $\mathrm{SC}$ & -52.3691 & -27.2815 \\
\hline FURB 6064 & 119 & P. nigrispinus & Usina Hidrelétrica de Itá - Itá & $\mathrm{SC}$ & -52.3691 & -27.2815 \\
\hline FURB 6503 & 119 & P. nigrispinus & Usina Hidrelétrica de Itá - Itá & $\mathrm{SC}$ & -52.3691 & -27.2815 \\
\hline UFSC 4849 & 112 & P. nigrispinus & $\begin{array}{l}\text { Morro do Caçador - Vargem do Bom Jesus - } \\
\text { Ilha de Santa Catarina }\end{array}$ & $\mathrm{SC}$ & -48.4264 & -27.4633 \\
\hline FURB 18732 & 117 & P. sulinus & Foz do Rio Caveiras- Abdom Batista & $\mathrm{SC}$ & -50.9344 & -27.5761 \\
\hline BMNH 50.7.8.24 & 113 & P. sulinus & Ilha de Santa Catarina & $\mathrm{SC}$ & -48.5 & -27.6 \\
\hline UFSC 4915 & 114 & P. nigrispinus & $\begin{array}{l}\text { Fazenda Ressacada - UFSC - Ilha de Santa } \\
\text { Catarina }\end{array}$ & $\mathrm{SC}$ & -48.5441 & -27.6851 \\
\hline UFSC 4214 & 115 & P. sulinus & Caldas da Imperatriz & $\mathrm{SC}$ & -48.8014 & -27.6856 \\
\hline
\end{tabular}




\begin{tabular}{|c|c|c|c|c|c|c|}
\hline UFPB JCV28 & 116 & P. sulinus & Serra do Tabuleiro & $\mathrm{SC}$ & -48.7833 & -27.8333 \\
\hline CIT 1346 & 118 & P. sulinus & Usina Hidrelétrica de Itá - Aratiba & RS & -52.3167 & -27.2667 \\
\hline MCNU 826 & 118 & P. sulinus & Usina Hidrelétrica de Itá - Aratiba & RS & -52.3167 & -27.2667 \\
\hline MCNU 833* & 118 & P. sulinus & Usina Hidrelétrica de Itá - Aratiba & RS & -52.3167 & -27.2667 \\
\hline MCNU 837 & 118 & P. sulinus & Usina Hidrelétrica de Itá - Aratiba & RS & -52.3167 & -27.2667 \\
\hline AC 632 & 120 & P. sulinus & $\begin{array}{l}\text { Parque Nacional Aparados da Serra - Cambará } \\
\text { do Sul }\end{array}$ & RS & -49.8333 & -29.25 \\
\hline MNRJ 21503 & 121 & P. dasythrix & São Francisco de Paula & RS & -50.5833 & -29.45 \\
\hline MNRJ 6238 & 125 & P. dasythrix & Pinheiros - Candelária & RS & -52.7333 & -29.7833 \\
\hline BMNH 1.12.3.1 & 122 & P. dasythrix & Porto Alegre & RS & -51.125 & -30.0792 \\
\hline MCNU 844* & 123 & P. dasythrix & Bairro Agronomia - Porto Alegre & RS & -51.1247 & -30.0792 \\
\hline MCNU 828* & 124 & P. dasythrix & Itapuã - Viamão & RS & -50.9667 & -30.4 \\
\hline
\end{tabular}


Capítulo 2

Filogeografia e delimitação de espécies em Gracilinanus agilis (Didelphimorphia, Didelphidae) nos biomas Cerrado e Caatinga 


\section{Introdução}

Os biomas da Caatinga, Cerrado e Chaco formam uma diagonal de formações abertas na América do Sul, caracterizadas por climas mais secos, alta sazonalidade das chuvas, e que isola os dois principais biomas florestais deste continente, Amazônia e Floresta Atlântica (Ab’Saber 1977). Um componente importante desta diagonal são as florestas decíduas e semi-decíduas - "Seasonally Dry Tropical Forests" (matas secas) (Pennington et al. 2006) - distribuídas em um grande maciço na Caatinga no nordeste do Brasil, presente em enclaves no Cerrado do Brasil central, outro maciço de menor tamanho no nordeste da Argentina e sul/centro-oeste do Brasil, se estendendo de forma disjunta através da Bolívia, Peru, Colombia, Venezuela e atingindo partes do México e sul dos Estados Unidas (Pennington et al. 2006). A hipótese do Arco Pleistocênico assume que as matas secas atingiram distribuição mais ampla durante o último máximo glacial e que sua atual condição disjunta é produto de uma fragmentação em função do aquecimento do clima após esse período (Prado \& Gibbs 1993). Por outro lado, modelos climáticos contradizem essa condição e indicam que as matas secas ampliaram sua distribuição após o último máximo glacial, durante o Holoceno (Werneck et al. 2011). As matas secas, no entanto, são pouco exploradas em estudos que buscam entender a evolução de sua diversidade biológica, a dinâmica de sua distribuição geográfica e seu papel em eventos de especiação e fragmentação ao longo do tempo, bem como a relação com a diversidade genética da sua biota associada (Werneck 2011).

Ideias iniciais propunham que a fauna de vertebrados relacionada às fitofisionomias de biomas associados a diagonal aberta como Cerrado e Caatinga seriam pobres em termos de riqueza de espécies e endemismos (e.g. Mares et al. 1985; Vanzolini 1974). Entretanto, revisões recentes indicam que 18,5\% das espécies de mamíferos desta região são endêmicas (Carmignotto et al. 2012), enquanto que novos inventários e estudos taxonômico descrevem novos táxons (e.g. Bonvicino et al. 2003; Bonvicino \& Weksler 1998; Tribe 2005; Weksler et al. 2006) e ampliam o entendimento de que o Cerrado, Caatinga e suas fitofisionomias associadas acumulam relevante diversidade biológica. Estudos sistemáticos e revisões taxonômicas são essenciais no sentido de descrever a diversidade dos componentes biológicos da diagonal de formações abertas. Por exemplo, Voss et al. (2005) identificou um novo gênero, Cryptonanus com representantes no Cerrado, previamente abrigado sob o nome Gracilinanus. Semedo et al. (2015), por sua vez, constataram que Gracilinanus 
peruanus seria outra forma previamente abrigada em agilis distribuída no extremo oeste do bioma Cerrado, e que agilis é o nome indicado para identificar indivíduos de outras regiões do Cerrado e Caatinga.

Gracilinanus agilis é uma espécie arborícola/escansorial que ocorre amplamente no Cerrado e Caatinga ocupando com alta frequência as regiões de matas secas presentes nestes biomas (Jansa et al. 2014). A validade desta espécie foi atestada por meio de filogenias moleculares e estudos anatômicos e diagnosticada como entidade taxonômica à parte de outras formas relacionadas (Costa et al. 2003; Lóss et al. 2011; Semedo et al. 2015). Diversos estudos filogenéticos e filogeográficos encontraram populações de G. agilis representadas em três clados principais (Costa et al. 2003; Faria et al. 2013; Lóss et al. 2011; Rocha et al. 2015): um composto por indivíduos provenientes da Caatinga e norte do Cerrado tendo como clado irmão um grupo composto de indivíduos provenientes do centro/sudoeste do Cerrado; e um terceiro clado que abriga indivíduos coletados na região leste do rio São Francisco derivado de uma divergência inicial na árvore de G. agilis e que forma o agrupamento de maior distância genética quando uma comparação par-a-par é realizada entre os clados recuperados nas filogenias (Rocha et al. 2015).

A Serra Geral de Goiás (localizada na região central do Cerrado) e o rio São Francisco estão entre os principais fatores utilizados para explicar as "quebras" filogeográficas associadas às populações de G. agilis (Faria et al. 2013) enquanto que o rio Araguaia é considerado como barreira ao fluxo gênico entre populações localizadas em margens opostas deste curso d'água (Rocha et al. 2015). Contudo, nenhuma associação entre a estruturação genética de populações de G. agilis e os principais fragmentos de matas secas foi realizada. Em virtude desta espécie de marsupial ser fortemente associada às matas secas, é possível que a estruturação genética de suas populações estejam relacionadas com a dinâmica temporal de fragmentação e expansão desta formação vegetal durante o Quaternário. Sendo assim, populações de G. agilis distribuídos na região da Caatinga devem apresentar sinais genéticos demográficos (expansão ou declínio populacional) estáveis visto que esta região é considerada uma área estável de matas secas (Prado \& Gibbs 1993; Werneck et al. 2011). Por outro lado, populações de G. agilis localizadas na região central/sudoeste do Cerrado devem apresentar desvios do modelo de população constante, indicando declínio ou expansão populacional em virtude das áreas de matas secas desta região apresentarem sinais de expansão e contração de sua distribuição ao longo do tempo (Werneck et al. 2011). 
O uso de dados genéticos tem permitido a identificação de espécies crípticas e “sibling species" (espécies crípticas irmãs - sensu Bickford et al. 2006 adaptado de Mayr 1963) tanto em organismos de distribuição restrita como táxons de distribuição ampla (e.g. Bock et al. 2012). Particularmente na diagonal de formações abertas, métodos de delimitação de espécies tem sido utilizados para identificar linhagens crípticas e verificar a validade de nomes atribuídos a sub-espécies (Oliveira et al. 2015; Werneck et al. 2015). Tais métodos de delimitação de espécies são associados ao conceito biológico de espécie (Mayr 1963) e combinam as árvores de gene e de espécie via processos coalescentes para inferir o tempo em que o fluxo gênico foi interrompido (ou reduzido) entre as linhagens comparadas (Yang \& Rannala 2010). No contexto de estruturação filogenética e geográfica de G. agilis, testes de delimitação de espécies podem ser úteis para inferir se a população do leste do rio São Francisco representa uma espécie distinta e se existe fluxo gênico considerável entre os clados norte e sul capaz de permitir considera-los pertencentes a mesma espécie.

O objetivo deste estudo foi testar se as populações de G. agilis são filogeneticamente estruturadas e se tal estruturação tem correspondência com os maciços de matas secas na Caatinga e no Cerrado. Além disso, foi aplicado um método de delimitação de espécies para verificar se existem linhagens crípticas nas diferentes populações de G. agilis. Métodos filogeográficos, inferências demográficas e datação molecular são aplicados numa perspectiva coalescente com base num conjunto de dados "multilocus" (i.e. sequências de DNA provenientes de regiões distintas do genoma).

\section{Materiais e Métodos}

Amostras, procedimentos de laboratório e tratamento das sequências

Foram utilizados 94 amostras de tecido de espécimes de G. agilis provenientes de localidades do Cerrado e da Caatinga (Anexo 1.2). Estas amostras foram obtidas a partir de expedições realizadas durantes os anos de 2014 e 2015 e de doações de colegas pesquisadores e coleções científicas de outras instituições do Brasil. Uma lista com o número de tombamento e/ou número de coleta de campo, localidade de coleta e coordenadas geográficas é fornecida no anexo 2.2. Além deste conjunto de dados, foram obtidas 90 sequências do gene citocromo $b$ (cyt-b) de espécimes de G. agilis depositadas no GenBank (plataforma online e repositório de dados moleculares). Uma lista com número de cada sequência obtida no GenBank, localidade de coleta, 
coordenadas geográficas e respectiva referência bibliográfica é fornecida no anexo 3.2. Os táxons Gracilinanus microtarsus, G. peruanus, Marmosa murina e Cryptonanus sp. foram utilizados como grupos externos paras as reconstruções filogenéticas. Esta amostragem contempla espécies do mesmo clado e de outros mais distantes em relação a G. agilis (Jansa et al. 2013)

O DNA das amostras foi extraído utilizando o método de fenól-clorofórmio e a qualidade das extrações foi avaliada através de uma eletroforese em gel de agarose 1,5\%. Foram amplificados 709 pares de bases (pb) do gene mitocondrial cyt-b (Smith \& Patton, 1993) e três introns nucleares (Giarla 2013; Giarla \& Jansa 2014): peptidylprolyl isomerase C (PPIC), $643 \mathrm{pb}$; prolyl 4- hydroxylase beta, (P4HB), $633 \mathrm{pb}$; O-Linked $N$ acetylglucosamine transferase (OGT, ligado ao cromossomo X), $654 \mathrm{pb}$. As sequências dos primers utilizados e respectivas referências são apresentadas no anexo 4.2. A escolha desses marcadores genéticos foi realizada com o objetivo de se abranger períodos curtos (cyt-b e OGT) e longos (nucleares autossômicos PPIC e P4HB) de eventos coalescentes, e desta maneira assegurar resolução para divergências recentes e antigas das linhagens estudadas.

As reações de amplificação (Reação em Cadeia da Polimerase - PCR) dos marcadores selecionados foram realizadas em um volume final de $20 \mu$ utilizando-se 1,5 $\mathrm{mM}$ de $\mathrm{MgCl}_{2}, 0,2 \mathrm{mM}$ de dNTPs, $0,2 \mu \mathrm{M}$ de cada primer, 1,5U de Taq DNA Polimerase (Invitrogen) e $30 \mathrm{ng}$ de DNA, e ciclos de temperatura compostos por um passo de desnaturação inicial a $95{ }^{\circ} \mathrm{C}$ por 5 min, seguidos por 35 ciclos de $95{ }^{\circ} \mathrm{C}$ por $45 \mathrm{seg}, 48-56{ }^{\circ} \mathrm{C}$ (conforme a temperatura de anelamento de cada primer) por $45 \mathrm{seg} \mathrm{e}$ $72{ }^{\circ} \mathrm{C}$ por $45 \mathrm{seg}$, finalizando com uma etapa de extensão à $72{ }^{\circ} \mathrm{C}$ por $10 \mathrm{~min}$. Pequenas adequações foram realizadas neste protocolo padrão para algumas amostras e espécies, conforme a necessidade.

Os produtos resultantes da Reação em Cadeia da Polimerase foram purificados com enzimas ExoSap (USB Corporation) e sequenciados pelo método Sanger na empresa Macrogen Inc. (Seoul, Korea) e no Centro de Genômica do Distrito Federal, localizado na Universidade Católica de Brasília. As sequências foram editadas no programa GENEIOUS 6.1 (Biomatters) e a fase gamética dos marcadores nucleares estimada pelo algoritmo PHASE (Stephens et al. 2001) implementado no programa DNASP 5.10 (Librado \& Rozas 2009). O alinhamento foi feito utilizando o algoritmo Muscle (Edgar 2004) e implementado no programa MEGA V. 5 (Tamura et al. 2011). Modelos de evolução nucleotídica de cada marcador molecular foram estimados no programa jModelTest 2 (Darriba et al. 2012) utilizando o critério de informação de 
Akaike. Com base nos scores de máxima verossimilhança, os modelos mais ajustados aos conjuntos de dados foram HKY (Hasegawa et al. 1985) com proporção de sítios invariáveis estimados (I) e distribuição gamma (G) para cyt-b; TIM1 (Posada 2003) para OGT; TIM1+I para P4HB; e TrN+I para PPIC (Tamura \& Nei 1993).

\section{Agrupamentos populacionais e árvores de gene}

Para avaliar o papel das matas secas e do rio São Francisco no isolamento das populações de G. agilis foram utilizadas sequências do gene cyt-b geradas no presente estudo e sequências disponíveis no GenBank, totalizando 184 sequências. Para isso, uma análise de agrupamentos genéticos foi conduzida no programa Bayesian Analysis of Population Structure - BAPS v 6 (http://www.helsinki.fi/bsg/software/BAPS/) utilizando o algoritmo clustering with linked loci (Corander et al. 2008). Foi utilizado um vetor como número mínimo de $K$ (número de populações) de 33335555777 79999101010 10, indicando que foram executadas 20 rodadas dentre quatro réplicas de valores de $K$ distintos. Na análise de admixture foram implementadas 100 iterações com cinco indivíduos tomados como referência em cada iteração e com 200 iterações adicionais para troca de indivíduos utilizados como referência. Por último, a análise de admixture foi implementada dez vezes para se verificar a consistência dos resultados.

Análises filogenéticas sob uma abordagem bayesiana foram implementadas para cada conjunto de dados separadamente (cyt-b, OGT, P4HB e PPIC). Estas análises foram realizadas numa perspectiva exploratória, de forma a encontrar correspondência entre os agrupamentos genéticos propostos pelo programa BAPS e a formação de clados das filogenias. Para isso foi utilizado o programa MrBayes (Huelsenbeck \& Ronquist 2001) versão 3.2.2 (disponível em http://mrbayes.sourceforge.net). Os resultados das estimativas de modelos de evolução nucleotídica provenientes do jModelTest2 foram utilizados como priors nas inferências bayesianas. Valores de frequência de bases e taxas de substituição nucleotídica foram ajustados como valores iniciais em uma distribuição Dirichlet, enquanto parâmetros de gamma shape e proporção de sítios invariáveis foram ajustados como fixos. Foram implementadas duas cadeias de Markov Chain Monte Carlo (MCMC) com 10 milhões de gerações cada e amostragens a cada 1000 gerações. O programa TRACER v1.3 (Rambaut \& Drummond 2007) foi usado para verificar a convergência dos valores de máxima verossimilhança e valores de tamanho efetivo das amostragens (ESS > 200). Ao final, 25\% das árvores amostradas foram 
descartadas como "burn-in" e um filograma foi construído utilizando apenas nós retidos em no mínimo 50\% das amostragens.

\section{Árvore de espécies, datação molecular e inferências demográficas}

Uma estimativa de árvore de espécies foi conduzida no programa BEAST 2 (Bouckaert et al. 2014) utilizando o algoritmo do pacote *BEAST (Heled \& Drummond 2010). Esta análise faz uso de uma abordagem coalescente e necessita que para cada indivíduo seja atribuída uma espécie ou qualquer outro nível de agrupamento (e.g. população) em que o mesmo está incluído. Sendo assim, cada indivíduo foi associado a uma das quatro populações (ver Resultados) inferidas pelo programa BAPS. Não foi possível obter sequências de genes nucleares para uma das quatro populações (de menor tamanho, destacada em vermelho na Figura 1) e, em função disso, este agrupamento genético não foi considerado na análise de árvore de espécies. Esta análise foi implementada com dois conjuntos de dados, um com as sequências obtidas para todos os genes e outro com sequências dos genes cyt-b e PPIC (os quais apresentaram maior variação entre os genes trabalhados). Uma taxa de mutação fixa de $2 \%$ a cada um milhão de anos foi associada ao gene cyt-b utilizando relógio molecular estrito. Esta taxa de mutação é estimada como uma média para o genoma mitocondrial de várias linhagens de mamíferos (Kumar \& Subramanian 2002) e utilizada em outros trabalhos de evolução e biogeografia de pequenos mamíferos neotropicais (e.g. Gutiérrez et al. 2014). Para os demais genes também foi utilizado o relógio molecular estrito porém permitindo uma estimativa de suas taxas de mutação. Foi utilizado um modelo de evolução nucleotídica para cada partição (sequências de cada gene) de acordo com os modelos ótimos estimados no programa jModelTest. A árvore de espécies foi estimada com tamanho de população linear ao longo do tempo, utilizando o prior coalescent constant population e a taxa de mutação de cada gene (menos cyt-b) estimada a partir de uma distribuição log-normal com média 1.0 e desvio padrão 1.25. Os demais parâmetros foram mantidos no default e seguindo as recomendações do manual do programa. Esta análise foi ajustada para 100.000.000 de simulações de MCMC com amostragens a cada 10.000 gerações. A convergência das amostragens e valores de ESS foram visualizada no programa TRACER v1.3 (Rambaut \& Drummond 2007). Foram implementadas duas corridas desta análise a fim de verificar convergência dos resultados. Os arquivos das corridas independentes (arquivos .log) foram combinados no programa LogCombiner 
e sumarizados no programa TreeAnotator, onde $20 \%$ das primeiras árvores amostradas foram descartadas como "burn-in".

Para se verificar sinais de alterações demográficas ao longo do tempo foram utilizadas as estatística D de Tajima (Tajima 1989), R2 de Ramos-Onsins e Rozas (Ramos-Onsins \& Rozas 2002) e Fs de Fu (Fu 1997), que testam desvios da neutralidade com base na frequências de mutações, e Fu's Fs (Fu 1997) com base na frequência de haplótipos. Estas estatísticas foram estimadas no programa DNASP v5.10 (Librado \& Rozas 2009) em simulações coalescentes de 10.000 replicações para determinar valores de probabilidade $(P<0,05$ considerado significativo) de cada estatística. Para estas análises, somente sequências do gene cyt-b foram utilizadas.

A história demográfica das diferentes populações também foi investigada utilizando Bayesian Skylines Plots (BSP) implementado no BEAST 2. Para esta análise também foram utilizadas apenas as sequências de cyt-b de cada população, sendo que a taxa de mutação, os modelos de evolução e os priors utilizados foram os mesmos daqueles utilizados na inferência da árvore de espécies. Igualmente, esta análise foi implementada com 100.000.000 de simulações de MCMC com amostragens a cada 10.000 gerações, e a convergência entre as cadeias e valores de ESS foram verificadas no programa TRACER v1.3, que também foi utilizado para construir os gráficos BSPs.

\section{Delimitação de espécies}

Foi aplicado um método de delimitação de espécies utilizando o programa Bayesian Phylogenetic and Phylogeography (BP\&P v3.2) (Yang \& Rannala 2010) utilizando as amostras qeu possuem sequências para todos os genes sequenciados. Este método tem como premissa ausência de fluxo gênico após a divergência das espécies (Yang \& Rannala 2010), apesar de que simulações indicam que baixo níveis de migração não afetam os modelos de delimitação propostos pelo algoritmo do BP\&P (Zhang et al. 2011). Em linhas gerais estas premissas estão em consonância com o conceito biológico de espécie proposto por Mayr (1963) que define espécie como um grupo que troca genes e é reprodutivamente isolado de outro grupo. $\mathrm{O}$ BP\&P utiliza uma abordagem coalescente com base em genealogias de múltiplos loci independentes e árvore de espécies e, a partir de uma cadeia MCMC, calcula a probabilidade posterior de diferentes modelos (hipóteses) de espécies. Tamanho populacional ancestral $(\theta)$ e idade da raiz da árvore $(\tau 0)$ são priors ajustados a uma distribuição gama $G(\alpha, \beta)$ que afetam sensivelmente a probabilidade posterior e a 
validação de cada espécie (Leaché et al. 2010), como por exemplo valores altos de $\theta$ e baixos de $\tau 0$ com tendências a favorecer modelos contendo poucas espécies (Yang \& Rannala 2010). Frente a isso, seguiu-se a recomendação de Leaché et al. (2010) implementando diversas rodadas do programa e empregando a seguinte combinação de priors: população grande $\theta \sim G(1,10)$ e divergências profundas $\tau 0 \sim G(1,10)$ ambos com média de 0,1 e variância 0,01 ; população ancestral pequena $\theta \sim G(2$, 2000) e divergências recentes $\tau 0 \sim G(2,2000)$ ambos com média de 0,001 e variância de $5 \times 10^{-7}$; e combinação de população ancestral grande $\theta \sim G(1,10)$ e divergências recentes $\tau 0 \sim G(2,2000)$. Para cada combinação de parâmetros foram implementadas no mínimo cinco rodadas a fim de se verificar a congruência entre os resultados. Cada rodada foi implementada com 1.000.000 de gerações, amostragens a cada 5 gerações e "burn-in" de 10.000. Rodadas adicionais foram realizadas alterando a topologia da árvore guia, alterando os algoritmos disponíveis no programa (Yang 2015) e com um menor conjunto de dados (10 sequências por populações).

\section{Resultados}

Agrupamentos genéticos e árvores de gene

A análise de estruturação genética implementada no programa BAPS estimou quatro agrupamentos genéticos com base em sequências do gene cyt-b (Figura 1.2A). Dentre estes, três agrupamentos representam indivíduos provenientes de localidades distintas e demonstram estruturação geográfica evidente: um grupo ocupando a região central/norte do Cerrado e Caatinga, outro na região central/sudoeste do Cerrado e o terceiro agrupamento genético restrito à região leste e sul do rio São Francisco na porção oriental da Caatinga e Cerrado. O quarto agrupamento genético, representado por oito sequências obtidas de indivíduos coletados nas regiões central e sul do cerrado, não apresenta evidência de estruturação geográfica.

A análise filogenética utilizando 184 sequências do gene cyt-b de espécimes de G. agilis indica monofiletismo da espécie com alta probabilidade posterior $(\mathrm{pp}=1)$ (Figura 1.2B). Esta análise indica a formação de quatro clados principais e possui moderada correspondência com os agrupamentos genéticos indicados pela análise no programa BAPS. Dois clados reciprocamente monofiléticos são compostos por sequências de indivíduos também encontrados em grupos genéticos distintos no programa BAPS (destacados pela coloração verde e amarela na Figura 1.2). Estes clados representam indivíduos provenientes da região central/norte do Cerrado e 
Caatinga (em verde na Figura 1.2) e região central/sudoeste do Cerrado (em amarelo na Figura 1.2). Dois clados derivados das primeiras divergências na árvore de $G$. agilis (clado 1 e 2 destacados em azul na Figura 1.2B) são representados por sequências de espécimes provenientes da região leste do rio São Francisco. Indivíduos destes clados foram encontrados no mesmo agrupamento genético pelo programa BAPS.

As análises filogenéticas implementadas com base em sequências dos marcadores nucleares indicaram baixa resolução (Figura 2.2A). O filograma resultante de sequências do PPIC indica com alto apoio estatístico $(\mathrm{pp}=1)$ o monofiletismo de G. agilis e moderada resolução filogenética. Esta análise demonstra a formação de dois clados, o primeiro composto por sequências de indivíduos originários da região leste da Caatinga localizadas à leste do rio São Francisco. O segundo clado é composto por sequências de espécimes das outras localidades amostradas e não apresenta correspondência com uma estruturação geográfica. As análises filogenéticas resultantes das sequências do OGT e P4HB indicaram monofiletismo de G. agilis e uma politomia basal que dificulta o entendimento de correlação entre grupos de sequências e localidades geográficas (Figura 2.2A). 


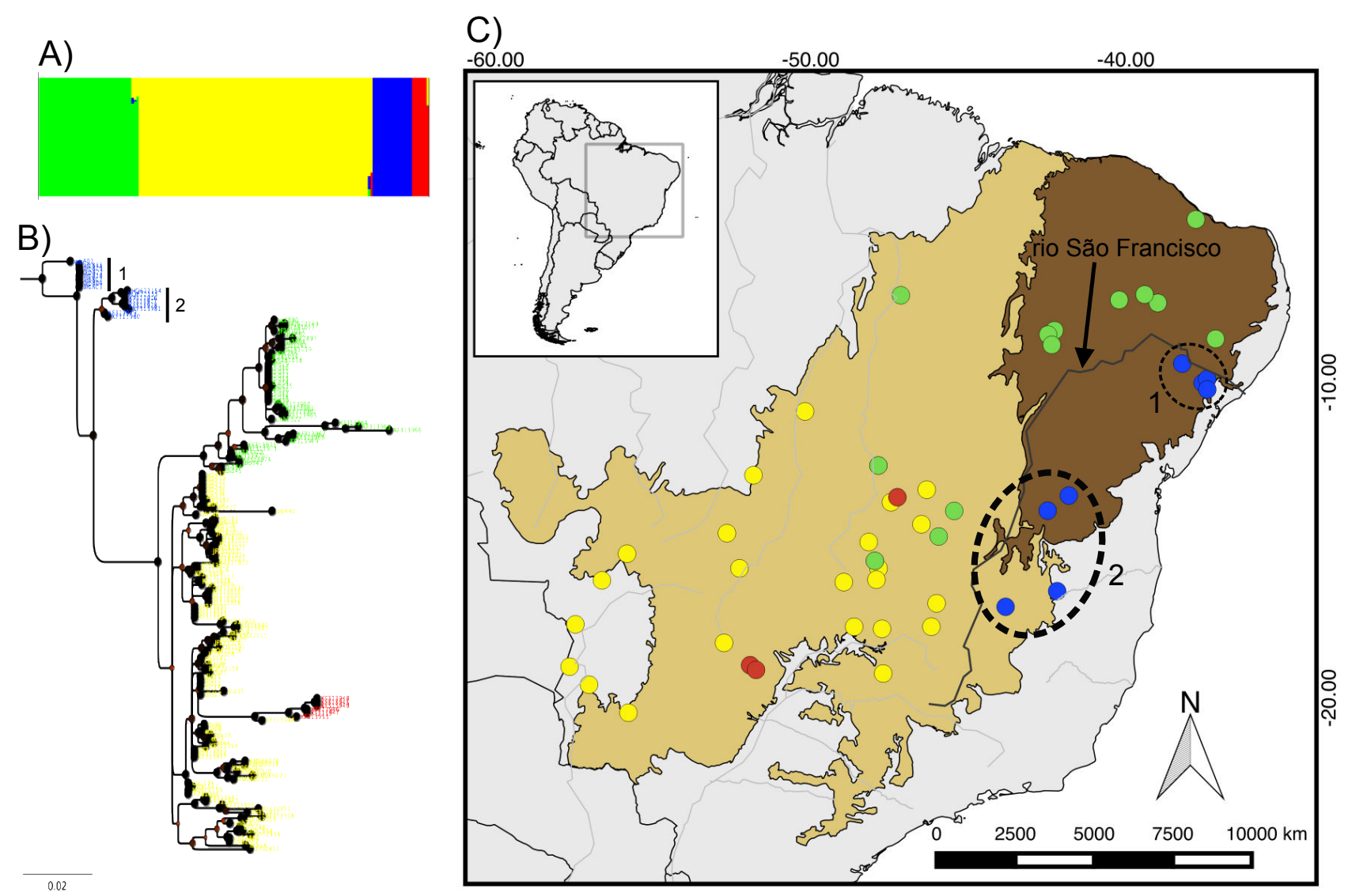

Figura 1.2: A) Grupos genéticos indicados pela análise no programa BAPS; B) Filograma resultante da análise filogenética com base em sequências do cyt-b realizada no programa MrBayes. Nós com círculo preto apresentam probabilidade posterior > 0,95; C) Mapa mostrando Cerrado em bege, Caatinga em marrom e rio São Francisco em cinza. Cores das barras em figura A e dos terminais da filogenia em B indicam correspondência com as localidades de mesma coloração da figura C. Círculos tracejados de números "1" e "2" indicam correspondência com clados na filogenia. 


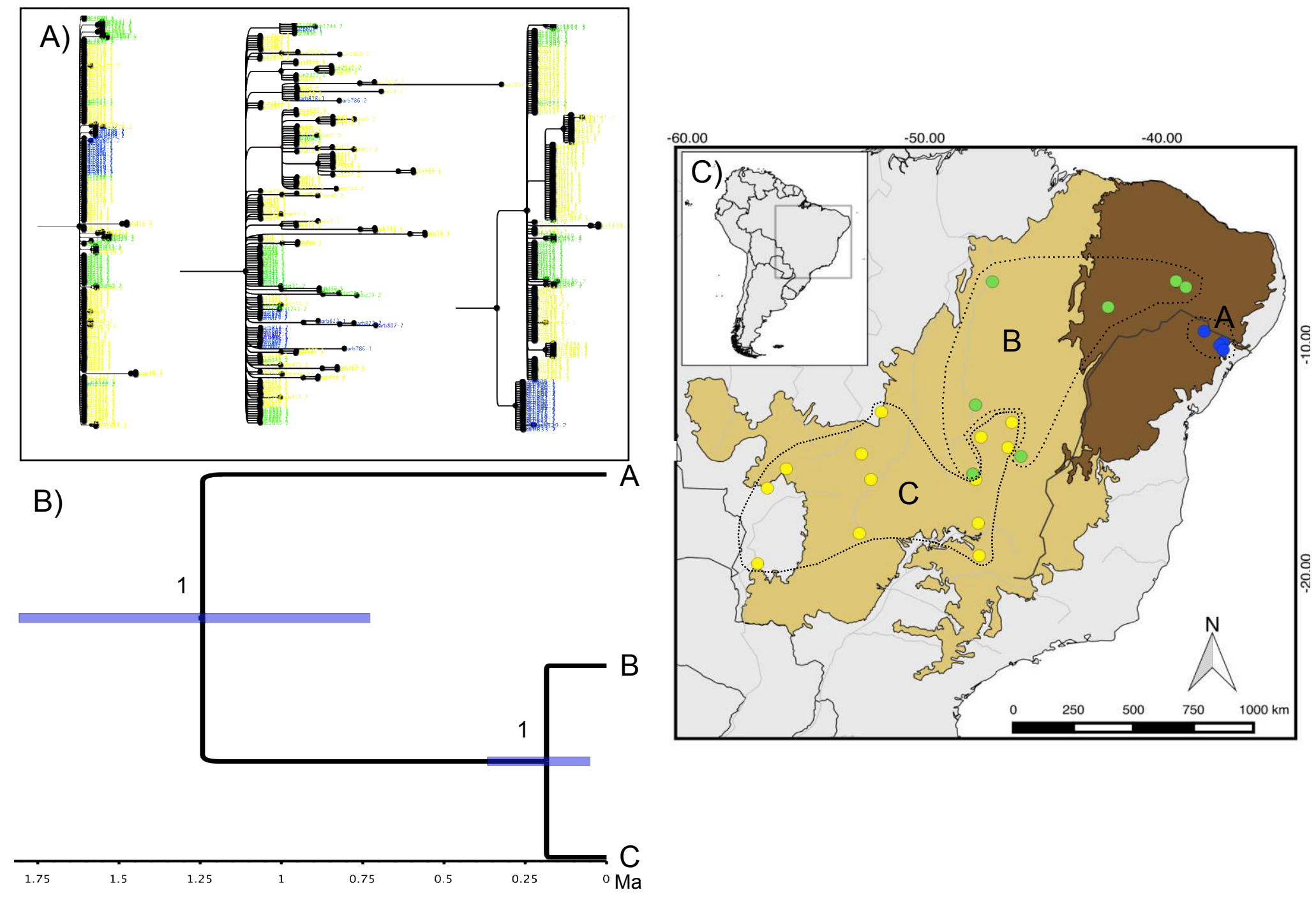

Figura 2.2: A) Filogenias de genes nucleares, da esquerda para direita: OGT, P4HB e PPIC. Nós com círculo em preto significam probabilidade superior > 0,95; B) Filogenia coalescente de espécies (cytb e PPIC): terminais A, B e C são populações derivadas das localidades correspondentes na figura C. C) mapa indicando localidades de origem das sequências analisadas nas árvores de gene e de espécie. Caatinga em marrom e Cerrado em bege. 
Árvore de espécies, datação molecular e inferências demográficas

As árvores de espécies utilizando sequências do conjunto de dados completo (todos os marcadores) não apresentaram convergência das cadeias de MCMC. Resultado oposto ocorreu quando somente os marcadores mais informativos (cyt-b e PPIC) foram utilizados. Nesta análise três linhagens principais foram encontradas (A, $\mathrm{B}$ e C na Figura 2.2B) e tem correspondência com os agrupamentos genéticos e clados encontrados na análise do programa BAPS e nas árvores de gene do cyt-b e PPIC. Dentre estas linhagens, " $\mathrm{C}$ " representa a população restrita a porção central/sudoeste do Cerrado; "B" representa a população restrita a porção central/norte do Cerrado e Caatinga; "A" corresponde a população localizada na Caatinga na porção leste do rio São Francisco. Estas relações evolutivas foram estimadas com alto valor de apoio estatístico $(\mathrm{pp}=1)$. A população " $\mathrm{A}$ " foi estimada com um tempo de isolamento das demais populações de aproximadamente 1,25 milhões de anos, enquanto que as populações "B" e "C" apresentaram o tempo de divergência de seu ancestral comum mais recente de aproximadamente 200.000 anos.

Testes de neutralidade com base em sequências do cyt-b apresentaram valores significativos de $D e R_{2}$ apenas para a população "C" (Tabela 1.2), enquanto que as demais populações apresentaram resultados que não rejeitam o modelo de população constante ao longo do tempo. De maneira semelhante, os resultados das BSPs indicam a população "C" com uma tendência de crescimento ao longo do tempo e as demais populações com tamanho populacional constante (Figura 3.2).

Table 1.2: Resultados obtidos nos testes de desvios do modelo neutro de evolução para as diferentes populações encontradas. Indicadores estatísticos utilizados: $D$ de Tajima, $F s$ de Fu e $R_{2}$ de Ramos-Onsins and Rozas.

\begin{tabular}{llll}
\hline População & $D$ & Fs & $R_{2}$ \\
\hline Pop. A & -1.76 & -2.15 & 0.31 \\
Pop. B & -1.06 & -1.18 & 0.09 \\
Pop. C & -1.32 & $-2.82^{*}$ & $0.06^{*}$ \\
\hline
\end{tabular}

* Valores estatisticamente significativos $(\mathrm{P}<0,05)$ 

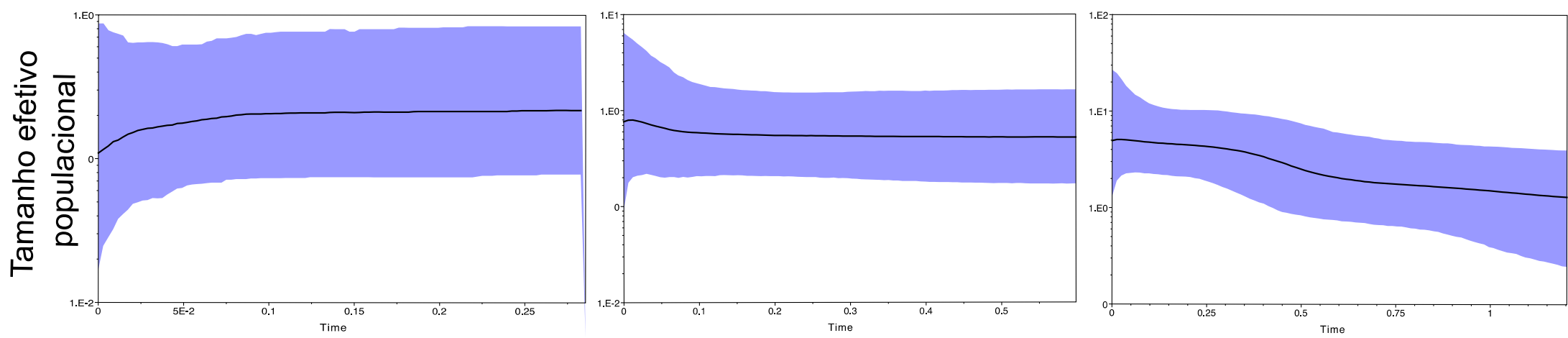

Tempo (milhões de anos)

Figura 3.2: Tamanho efetivo populacional através do tempo das populações A (esquerda), B (centro), C (direita) de G. agilis com base em Bayesian Skyline Plots. Área em azul representa intervalo de 95\% de HPD. 


\section{Delimitação de espécies}

A análise de delimitação de espécies realizada no programa BP\&P indicou a presença de três espécies ( $\mathrm{pp}=1)$, que possuem associação direta com os clados recuperados na árvore de gene do cyt-b e na árvore de espécies. O mesmo resultado foi obtido em todas as análises onde os valores dos priors $\theta$ e $\tau 0$ e demais parâmetros como algoritmo, árvore guia e número de amostras por população foram alterados.

\section{Discussão}

O conjunto de resultados encontrados aqui permite delinear que G. agilis possui três linhagens evoluindo independentemente: população A da região leste do rio São Francisco, população B proveniente da região central/norte do Cerrado e Caatinga e população $\mathrm{C}$ da região sul/sudoeste do Cerrado. A primeira população está isolada há mais tempo em relação às outras (1.25 Ma) enquanto que separação das populações B e C foi mais recente (200.000 mil anos). Apesar da baixa resolução dos marcadores nucleares e incongruências com a árvore derivada da análise do cyt-b, as filogenias resultantes do cyt-b e do PPIC foram semelhantes em demonstrar que a população proveniente do leste do Rio São Francisco forma um clado derivado da primeira divergência na árvore de G. agilis. A árvore coalescente de espécies também demonstrou esta tendência, além de apontar correspondência com os demais clados recuperados na árvore do cyt-b. Incongruências entre árvores de genes de marcadores mitocondriais e nucleares é encontrada com frequência em organismos de divergência recente e tem como principais causas a retenção de polimorfismo ancestral e separação incompleta das linhagens ("incomplete lineage sorting") (Knowles \& Carstens 2007; Toews \& Brelsford 2012). Neste sentido que se fazem necessárias, como realizado neste trabalho, a aplicação de métodos coalescentes que acomodem incongruências de marcadores independentes (Page \& Charleston 1997; Rosenberg \& Nordborg 2002).

A estruturação filogenética e geográfica com base em sequências do gene cyt-b encontrada aqui é semelhante a de demais estudos (Costa et al. 2003; Faria et al. 2013; Lóss et al. 2011; Rocha et al. 2015). Porém, quando os diferentes marcadores foram analisados de forma simultânea na árvore de espécie encontramos que a população A (leste do rio São Francisco) é resultado de uma divergência mais antiga, 
enquanto que as populações B e C formam clados irmãos. Estes resultados são contrários ao encontrado por Faria et al. (2013) que, utilizando sequências do exon 28 do gene nuclear fator de Von Willenbrand (vWF), recuperaram indivíduos do leste do rio São Francisco (equivalente à população $\mathrm{A}$ ) como irmãos dos indivíduos do norte da Caatinga (equivalente à população B). Entretanto é preciso levar em conta que as filogenias com base em sequências do vWF não possuem apoio estatístico para assegurar o monofiletismo de G. agilis (Faria et al. 2013) e que análises coalescentes multigênicas jamais foram empregadas para este organismo. Por outro lado, no presente estudo foi encontrado monofiletismo de G. agilis em todas filogenias de gene e de espécie, sendo que os métodos aqui apresentados estão alinhados à perspectiva da teoria coalescente e análises multigênicas, que em última análise estão na vanguarda da filogeografia moderna (Avise 2009; Hickerson et al. 2010).

Foram constatadas evidências de crescimento populacional de G. agilis na população $\mathrm{C}$ e indicativos de estabilidade ao longo do tempo para as populações $\mathrm{A}$ e B. Estes resultados podem ser interpretados frente a dinâmica de distribuição das matas secas. Algumas hipóteses indicam que a Caatinga é uma região de estabilidade de matas secas, enquanto que porções de matas secas do Cerrado e sudoeste do Brasil sofreram eventos de fragmentação ao longo do tempo (Prado \& Gibbs 1993; Werneck et al. 2011). Ademais, as matas secas poderiam apresentar uma distribuição muito mais ampla e contígua no Neotrópico durante o Terciário e Quaternário e mudanças climáticas mais recentes teriam orientado uma distribuição atual disjunta (Pennington et al. 2000; Pennington et al. 2004). Neste cenário, os enclaves de matas secas atuais do Cerrado (Felfili et al. 2006; Oliveira-Filho \& Ratter 1995) poderiam ser remanescentes de uma formação maior que passou por fragmentação no último máximo glacial e que hoje estariam se expandindo (Werneck et al. 2011). Esta dinâmica poderia explicar por que na área da Caatinga e norte do Cerrado ocorrem populações estáveis e antigas de G. agilis (Populações A e B) e que a linhagem presente no sul/sudoeste do Cerrado (população C) apresenta desvios do modelo neutro populacional decorrente de simultâneas expansões e fragmentações da matas secas.

Tanto análises com sequências de cyt-b utilizadas em trabalhos previamente publicados (e.g. Faria et al. 2013; Rocha et al. 2015) como as análises utilizando sequências inéditas (genes nucleares e mitocondrial) indicaram conjuntos genéticos restritos à leste do rio São Francisco. Este rio tem sido utilizado como modelo em 
estudos que testam hipóteses de rios como barreiras ao fluxo gênico (e.g. Faria et al. 2013; Nascimento et al. 2013; Oliveira et al. 2015; Percequillo et al. 2008). Apesar de diferentes organismos apresentarem clados restritos à leste deste rio, algumas linhagens de mamíferos e lagartos demonstram fluxo gênico recente entre indivíduos distribuídos em ambas as margens do rio (Nascimento et al. 2013; Oliveira et al. 2015). Frente a isso, não parece adequado supor que o rio como barreira per se seja suficiente para impedir acasalamentos entre indivíduos de populações adjacentes. Sendo assim, outros fatores promotores de isolamento têm sido propostos como alternativa para estruturação genética. Por exemplo, supõe-se que a cadeia de montanhas localizada à leste do rio São Francisco (cadeia do Espinhaço) atue como barreira para lagartos de pequeno tamanho (Oliveira et al. 2015), e que o paleo-curso e meandros abandonados da foz do rio São Francisco também sejam promotores de estruturação genética em roedores e lagartos (Nascimento et al. 2013; Werneck et al. 2015). Além disso, pode-se supor que retrações e expansões de matas secas em ambas as margens do rio São Francisco poderiam ser um agente adicional que igualmente contribui com a estruturação genética de populações distribuídas nas margens oriental e ocidental do rio.

A análise de delimitação de espécies indicou que cada uma das três populações recuperadas nas filogenias representam espécies diferentes (probabilidade posterior $=$ 1), e que portanto G. agilis seria um complexo de espécies. Adicionalmente a este método de delimitação de espécie, a população A poderia ser considerada uma espécie distinta se esquemas taxonômicos fossem propostos com base no conceito filogenético de espécie (Cracraft 1983), visto que em duas árvores de gene e na árvore coalescente de espécie esta população é monofilética e distante das demais. Um indicativo contrário pode ser visto na ausência desta tendência em outros dois genes analisados (OGT e P4HB). Contudo, simulações indicam probabilidades baixas de monofiletismo recíproco entre espécies de separação recente em função de retenção de polimorfismo ancestral, "lineage sorting" ainda muito atuantes (Knowles \& Carstens 2007), hibridização e introgressão (Zhang et al. 2011). Assim, a taxonomia de organismos com esta natureza não é uma tarefa simples e requer uma análise mais profunda de conceitos de espécie e métodos de validação e delimitação de espécies (de Queiroz 2007).

Além de conjuntos de dados diferentes frequentemente produzirem hipóteses filogenéticas conflituosas, a falta de métodos e conceitos de espécies unificados (de 
Queiroz 2007) implica que, por vezes, a taxonomia se torne subjetiva. Por outro lado, a unificação de métodos de delimitação e conceitos de espécies permitiria o tratamento de uma entidade específica como hipótese científica passível de teste. Métodos coalescentes de delimitação tentam atingir este objetivo (Zhang et al. 2011), na medida em que empregam um ou mais modelos teóricos (i.e. conceitos de espécie) e procedimentos estatísticos para gerar probabilidades de determinada linhagem ser considerada uma espécie distinta. Este procedimento é particularmente útil se considerarmos tempos de divergências recentes, como encontrado em G. agilis, e onde diferenças morfológicas ou ecológicas ainda não foram suficientemente acumuladas gerando dessa forma conflitos conceituais. Por exemplo, a propriedade fundamental do conceito fenético assume que diferentes espécies apresentam formas distintas, porém duas espécies podem conservar formas semelhantes e serem reciprocamente monofiléticas e com ausência de fluxo gênico (de Queiroz 2007). Analogamente, o nicho ecológico, propriedade intrínseca do conceito ecológico de espécie, pode ser conservado para duas espécies distintas de divergência recente (Wiens 2004). Estes fenômenos ocorrem porque as diferentes propriedades de cada conceito de espécie (e.g. forma para o fenético, nicho para o ecológico) não mudam na mesma intensidade e no mesmo tempo em que duas linhagens vão se separando (de Queiroz 2007). Portanto, uma abordagem integrativa se faz necessária. No contexto de G. agilis, a incorporação de informações morfológicas, ecológicas e dados genéticos adicionais à delimitação de espécies aplicadas no presente estudo seria particularmente importante para validar ou refutar a hipótese deste táxon abrigar um complexo de espécies.

O presente estudo utilizou conjuntos de dados inéditos e métodos filogeográficos clássicos e coalescentes. Os resultados obtidos oferecem novas hipóteses sobre a evolução de G. agilis e sua relação com as regiões que esta espécie ocupa. Uma destas hipóteses é de que a dinâmica histórica de expansão e contração de matas secas desempenham um fator determinante para a estruturação genética e geográfica de G. agilis. Outra hipótese é que as diferentes linhagens desta espécie podem se tratar de espécies distintas, fazendo com que G. agilis acumule mais de uma espécie. A integração de conjuntos de dados adicionais (e.g. morfologia) seria importante para validar a hipótese de que G. agilis abriga um complexo de espécies. 


\section{Referências bibliográficas}

Ab’Saber, A. N. (1977). Os domínios morfoclimáticos na América do Sul: primeira aproximação. Geomorfologia, 52, 1-22.

Avise, J. C. (2009). Phylogeography: retrospect and prospect. Journal of Biogeography, 36, 3-15.

Bickford, D., Lohman, D. J., Sodhi, N. S., Ng, P. K. L., Meier, R., Winker, K., ... Das, I. (2006). Cryptic species as a window on diversity and conservation. Trends in Ecology and Evolution, 22, 148-155.

Bock, D. G., Macisaac, H. J., \& Cristescu, M. E. (2012). Multilocus genetic analyses differentiate between widespread and spatially restricted cryptic species in a model ascidian. Proceedings of the Royal Society B: Biological Sciences, 279, $2377-2385$.

Bonvicino, C. R., \& Weksler, M. (1998) A New Species of Oligoryzomys (Rodentia, Sigmodontinae) from Northeastern and Central Brazil. Zeitschrift für Säugetierkunde, 63, 90-103.

Bonvicino, C. R., Lima, J. F. S. \& Almeida F. C. (2003). A New Species of Calomys Waterhouse (Rodentia, Sigmodontinae) from the Cerrado of Central Brazil. Revista Brasileira de Zoologia, 20, 301 -307.

Bouckaert, R., Heled, J., Kuhnert, D., Vaughan, T., Wu, C., Xie, D., ... Drummond, A. J. (2014). BEAST 2: A software platform for bayesian evolutionary analysis. Plos Computational Biology, 10, 1-6.

Carmignotto, A. P., Vivo, M. De, \& Langguth, A. (2012). Mammals of the Cerrado and Caatinga: distribution patterns of the tropical open biomes of central South America. In B. D. Patterson \& L. P. Costa (Eds.), Bones, clones and biomes. The history and geography of recent Neotropical mammals (pp. 307-350). Chicago, Illinois: University of Chicago Press.

Corander, J., Marttinen, P., Sirén, J., \& Tang, J. (2008). Enhanced Bayesian modelling in BAPS software for learning genetic structures of populations. BMC Bioinformatics, 9, 1-14.

Costa, L. P., Leite, Y. L. R., \& Patton, J. L. (2003). Phylogeography and sytematics notes on two species of gracile mouse opossum, genus Gracilinanus (Marsupialia: Didelphidae) from Brazil. Proceedings of the Biological Society of Washington, 116, 275-292. 
Cracraft, J. (1983). Species concept and speciation analysis. Current Ornithology, 1, $159-187$.

Darriba, D., Taboada, G.L., Doallo, R. \& Posada, D. (2012) Darriba, D., Taboada, G.L., Doallo, R. \& Posada, D. (2012) jModelTest 2: more models, new heuristics and parallel computing. Nature Methods, 9, 772-772.

Edgar, R.C. (2004) MUSCLE: a multiple sequence alignment method with reduced time and space complexity. BMC Bioinformatics, 32, 1792-1797.

Faria, M. B., Nascimento, F. F., Oliveira, J. A., \& Bonvicino, C. R. (2013). Biogeographic determinants of genetic diversification in the mouse opossum Gracilinanus agilis (Didelphimorphia: Didelphidae ). Journal of Heredity, 104, 613-626.

Felfili, J. M., Klink, C. A., Silva, J. F., \& Farin, M. R. (2006). Spatial heterogeneity, land use and conservation in the cerrado region of. Journal of Biogeography, 33, $536-548$.

Giarla, T. C., \& Jansa, S. A. (2014). The role of physical geography and habitat type in shaping the biogeographical history of a recent radiation of Neotropical marsupials (Thylamys: Didelphidae). Journal of Biogeography, 41, 1547-1558.

Gutiérrez, E. E., Anderson, R. P., Voss, R. S., Ochoa-G, J., Aguilera, M., \& Jansa, S. A. (2014). Phylogeography of Marmosa robinsoni: insights into the biogeography of dry forests in northern South America. Journal of Mammalogy, $95,1175-1188$.

Hasegawa, M., Kishino, K., \& Yano, T.(1985). Dating the human-ape splitting by a molecular clock of mitochondrial DNA. Journal of Molecular Evolution, 22, $160-174$.

Heled, J., \& Drummond, A. J. (2010). Bayesian inference of species trees from multilocus data. Molecular Biology and Evolution, 27, 570-580.

Hickerson, M. J., Carstens, B. C., Cavender-Bares, J., Crandall, K. a, Graham, C. H., Johnson, J. B., ... Yoder, a D. (2010). Phylogeography's past, present, and future: 10 years after Avise, 2000. Molecular Phylogenetics and Evolution, 54, 291-301.

Huelsenbeck, J.P. \& Ronquist, F. (2001) MRBAYES: Bayesian inference of phylogeny. Bioinformatics, 17, 754-755.

Jansa, S. A., Barker, F. K., \& Voss, R. S. (2014). The early diversification history of didelphid marsupials: a window into South America's "splendid isolation." 
Evolution, 68, 684-695.

Knowles, L. L., \& Carstens, B. C. (2007). Delimiting Species without monophyletic gene trees. Systematic Biology, 56, 887-895.

Kumar, S., \& Subramanian, S. (2002). Mutation rates in mammalian genomes. Proceedings of National Academy Society, 99, 803-808.

Leaché, A. D., \& Fujita, M. K. (2010). Bayesian species delimitation in West African forest geckos (Hemidactylus fasciatus). Proceedings of Royal Society Biological Sciences, 277, 3071-3077.

Librado, P., \& Rozas, J. (2009). DnaSP v5 : a software for comprehensive analysis of DNA polymorphism data. Bioinformatics, 25, 1451-1452.

Lóss, S., Costa, L. P., \& Leite, Y. L. R. (2011). Geographic variation, phylogeny and systematic status of Gracilinanus microtarsus (Mammalia: Didelphimorphia: Didelphidae). Zootaxa, 2761, 1-33.

Mares, M. A., Willig, M. R., \& Lacher, T. E. J. (1985). The Brazilian Caatinga in South American Zoogeography: tropical mammals in a dry rgion. Journal of Biogeography, 12, 57-69.

Mayr E. 1963. Animal species and evolution. Cambridge (MA): Belk nap Press.

Nascimento, F. F., Lazar, A., Menezes, A. N., Durans, M., Moreira, J. C., SalazerBravo, J., ... Bonvicino, C. R. (2013). The role of historical barriers in the diversification processes in open vegetation formations during the Miocene/Pliocene using an ancient rodent lineage as a model. Plos One, 8, 1-13.

Oliveira-Filho, A. T., \& Ratter, J. A. (1995). A study of the origin of central brazilian forests by the analysis of plant species distribution patterns. Edinburg Journal of Botany, 52, 141-194.

Oliveira, F. E., Gehara, M., São-Pedro, A. V., Chen, X., Myers, E. A., Burbink, F. T., ... Costa, G. C. (2015). Speciation with gene flow in whiptail lizards from a Neotropical xeric biome. Molecular Ecology, 24, 5957-5975.

Page, R. D. M., \& Charleston, M. A. (1997). From gene to organismal phylogeny: reconciled trees and the gene tree/species tree problem. Molecular Phylogenetics and Evolution, 7, 231-240.

Pennington, R. T., Lavin, M., Prado, D. E., Pendry, C. a, Pell, S. K., \& Butterworth, C. a. (2004). Historical climate change and speciation: neotropical seasonally dry forest plants show patterns of both tertiary and quaternary diversification. Philosophical Transactions of the Royal Society of London. Series B, Biological 
Sciences, 359, 515-37.

Pennington, R. T., Lewis, G. P., \& Ratter, J. A. (2006). Neotropical savannas and seasonally dry forests: plant diversity, biogeography, and conservation. (R. T. Pennington, G. P. Lewis, \& J. A. Ratter, Eds.). Boca Raton, FL: The Systematics Association.

Pennington, R. T., Pradot, D. E., Pendry, C. A., \& Botanic, R. (2000). Neotropical seasonally dry forests and Quaternary vegetation changes. Journal of Biogeography, 27, 261-273.

Percequillo, A. R., Hingst-Zaher, E., \& Bonvicino, C. R. (2008). Systematic review of genus Cerradomys Weksler, Percequillo and Voss, 2006 (Rodentia: Cricetidae: Sigmodontinae: Oryzomyini), with description of two new species from eastern Brazil. American Museum Novitates, 3622, 1-46.

Posada, D. 2003. Using Modeltest and PAUP* to select a model of nucleotide substitution. Pp. 6.5.1-6.5.14 in A. D. Baxevanis, D. B. Davison, R. D. M. Page, G. A. Petsko, L. D. Stein, and G. D. Stormo, eds. Current Protocols in Bioinformatics. John Wiley \& Sons, Inc.

Prado, D. E., \& Gibbs, P. E. (1993). Patterns of species distributions in the dry seasonal forest of the South Ameria. Annals of the Missouri Botanical Garden, 80, 902-927.

Queiroz, D. de. (2007). Species Concepts and Species Delimitation. Systematic Biology, 56, 879-886.

Rambaut, A. \& Drummond, A.J. (2007) Tracer. Ver. 1.4. Available from: http://beast.bio.ed.ac.uk/Tracer (accessed 1 November 2013)

Rocha, R. G., Ferreira, E., Loss, A. C., Heller, R., Fonseca, C., \& Costa, L. P. (2015). The Araguaia river as an important biogeographical divide for didelphid marsupials in central Brazil. Journal of Heredity, 106, 593-607.

Rosenberg, N. A., \& Nordborg, M. (2002). Genealogical trees, coalescent theory and the analysis of genetic polymorphisms. Nature, 3, 380-390.

Semedo, T. B. F., Brandão, M. V., Carmignotto, A. P., Nunes, M. da S., Farias, I. P., Silva, M. N. F. da, \& Rossi, R. V. (2015). Taxonomic status and phylogenetic relationships of Marmosa agilis peruana Tate, 1931 (Didelphimorphia: Didelphidae), with comments on the morphological variation of Gracilinanus from central-western Brazil. Zoological Journal of the Linnean Society, 173, $190-216$. 
Smith, M. F., \& Patton, J. L. (1993). The diversification of South American murid rodents: evidence from mitochondrial DNA sequence data for the akodontine tribe. Biological Journal of the Linnean Society, 50, 149-177.

Stephens M, Smith N. J., \& Donnelly, P. (2001) A new statistical method for haplotype reconstruction from population data. The American Journal of Human Genetics, 68, 978-989.

Tamura, K. \& Nei, M. (1993). Estimation of the number of nucleotide substitutions in the control region of mitochondrial dna in humans and chimpanzees. Molecular Biology and Evolution, 10, 512-526.

Tamura, K., Peterson, D., Peterson, N., Stecher, G., Nei, M. \& Kumar, S. (2011) MEGA5: molecular evolutionary genetics analysis using maximum likelihood evolutionary distance, and maximum parsimony methods. Molecular Biology and Evolution, 28, 2731-2739.

Toews, D. P. L., \& Brelsford, A. (2012). The biogeography of mitochondrial and nuclear discordance in animals. Molecular Ecology, 21, 3907-3930.

Tribe, C. J. 2005. A New Species of Rhipidomys (Rodentia, Muroidea) from NorthEastern Brazil. Arquivos do Museu Nacional, 63, 131 -146.

Vanzolini, P.E., 1976. On the lizards of a Cerrado-Caatinga contact, evolutionary and zoogeographical implications (Sauria). Papéis Avulsos de Zoologia, 29, 111119.

Voss, R. S., Lunde, D. P., \& Jansa, S. A. (2005). On the Contents of Gracilinanus Gardner and Creighton, 1989, with the Description of a Previously Unrecognized Clade of Small Didelphid Marsupials ROBERT. American Museum Novitates, 3482, 1-34.

Weksler, M., Percequillo, A. R., \& Voss, R. S. (2006). Ten New Genera of Oryzomyine Rodents (Cricetidae: Sigmodontinae). American Museum Novitates, $3537,1-29$.

Werneck, F. P. (2011). The diversification of eastern South American open vegetation biomes: Historical biogeography and perspectives. Quaternary Science Reviews, $30,1630-1648$.

Werneck, F. P., Costa, G. C., Colli, G. R., Prado, D. E., \& Sites Jr, J. W. (2011). Revisiting the historical distribution of Seasonally Dry Tropical Forests: new insights based on palaeodistribution modelling and palynological evidencegeb. Global Ecology and Biogeography, 20, 272-288. 
Werneck, F. P., Leite, R. N., Geurgas, S. R., \& Rodrigues, M. T. (2015). Biogeographic history and cryptic diversity of saxicolous Tropiduridae lizards endemic to the semiarid Caatinga. BMC Evolutionary Biology, 15, 1-24.

Wiens, J. J. (2004). Speciation and ecology revisited: phylogenetic niche conservatism and the origin of species. Evolution, 58, 193-197.

Yang, Z. (2015). The BPP program for species tree estimation and species delimitation. Current Zoology, 61, 854-865.

Yang, Z., \& Rannala, B. (2010). Bayesian species delimitation using multilocus sequence data. Proceedings of National Academy Society, 107, 9264-9269.

Zhang, C., Zhang, D. X., Zhu, T., \& Yang, Z. (2011). Evaluation of a Bayesian coalescent method of species delimitation. Systematic Biology, 60, 747-761. 
Anexo 1.2: Mapa indicando as localidades de origem das amostras de G. agilis utilizadas nas análises. Em marrom a Caatinga, em bege o Cerrado.

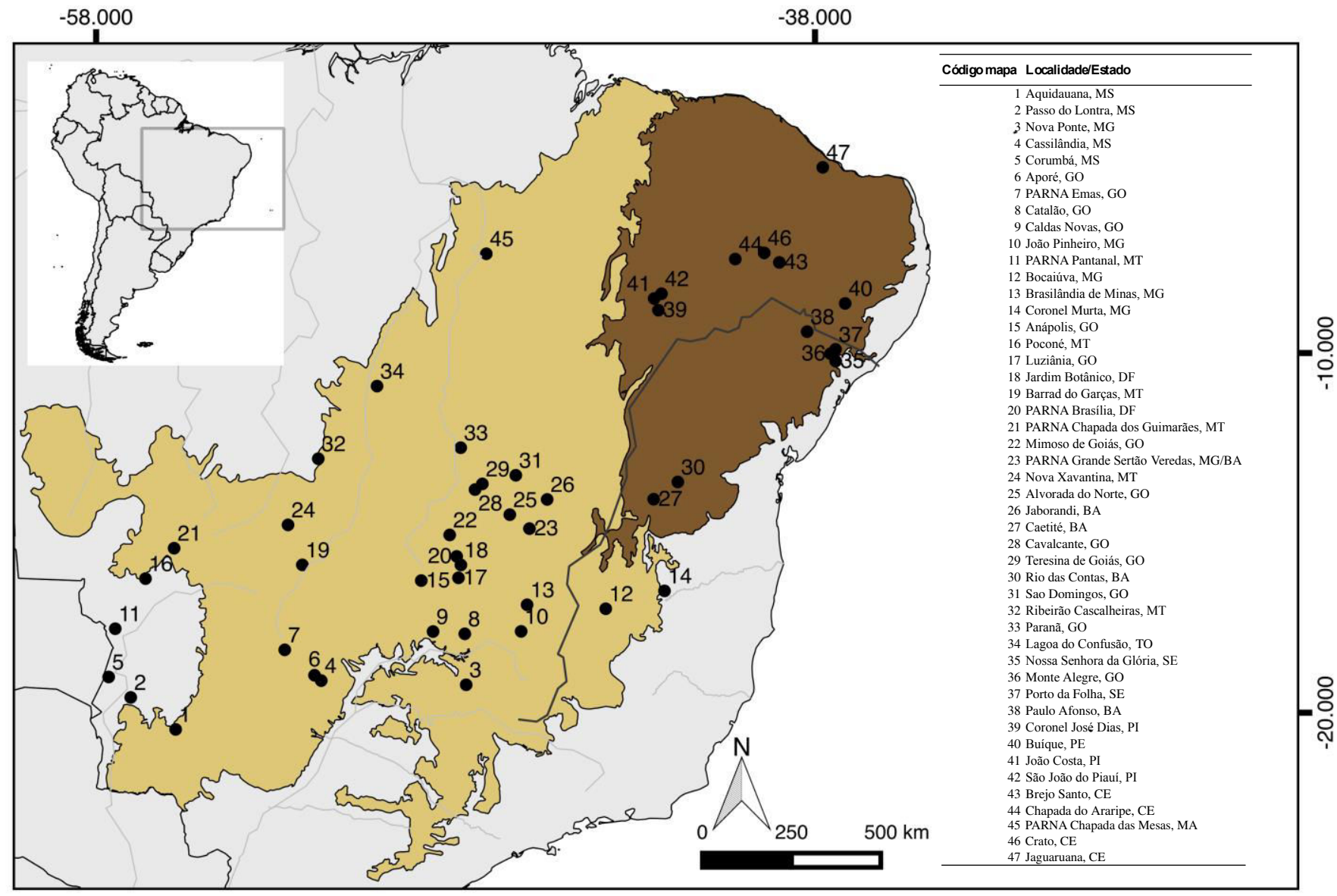


Anexo 2.2: Número de tombo ou coleta das amostras de tecidos de G. agilis utilizados no presente estudo, indicando localidade de coleta, Estado e coordenadas geográficas em graus decimais.

\begin{tabular}{|c|c|c|c|c|}
\hline Amostra & Município/localidade & Estado & Coordenada & \\
\hline AC2890 & Brejo Santo & CE & -7.48095 & -38.99019 \\
\hline AC2891 & Brejo Santo & CE & -7.48095 & -38.99019 \\
\hline AC2892 & São João do Piauí & $\mathrm{PI}$ & -8.35188 & -42.26958 \\
\hline AC2893 & São João do Piauí & $\mathrm{PI}$ & -8.35188 & -42.26958 \\
\hline AC2894 & São João do Piauí & $\mathrm{PI}$ & -8.35188 & -42.26958 \\
\hline ARB 417 & São Domingos & GO & -13.40405 & -46.32561 \\
\hline ARB 418 & São Domingos & GO & -13.40405 & -46.32561 \\
\hline ARB419 & São Domingos & GO & -13.40405 & -46.32561 \\
\hline ARB423 & São Domingos & GO & -13.40405 & -46.32561 \\
\hline ARB425 & São Domingos & GO & -13.40405 & -46.32561 \\
\hline ARB426 & São Domingos & GO & -13.40405 & -46.32561 \\
\hline ARB427 & São Domingos & GO & -13.40405 & -46.32561 \\
\hline ARB434 & São Domingos & GO & -13.40405 & -46.32561 \\
\hline ARB436 & São Domingos & GO & -13.40405 & -46.32561 \\
\hline ARB440 & São Domingos & GO & -13.40405 & -46.32561 \\
\hline ARB467 & Paranã & TO & -12.63331 & -47.85550 \\
\hline ARB475 & Paranã & TO & -12.63331 & -47.85550 \\
\hline ARB541 & Paranã & TO & -12.63331 & -47.85550 \\
\hline ARB548 & Paranã & TO & -12.63331 & -47.85550 \\
\hline ARB587 & Alvorada do Norte & GO & -14.49474 & -46.48910 \\
\hline ARB743 & Ribeirão Cascalheira & MT & -12.93987 & -51.81927 \\
\hline ARB744 & Ribeirão Cascalheira & MT & -12.93987 & -51.81927 \\
\hline ARB774 & Ribeirão Cascalheira & MT & -12.93987 & -51.81927 \\
\hline ARB786 & Monte Alegre de Sergipe & SE & -10.01911 & -37.56496 \\
\hline ARB802 & Monte Alegre de Sergipe & SE & -10.01911 & -37.56496 \\
\hline ARB803 & Monte Alegre de Sergipe & SE & -10.01911 & -37.56496 \\
\hline ARB806 & Monte Alegre de Sergipe & SE & -10.01911 & -37.56496 \\
\hline ARB807 & Monte Alegre de Sergipe & SE & -10.01911 & -37.56496 \\
\hline ARB808 & Monte Alegre de Sergipe & SE & -10.01911 & -37.56496 \\
\hline
\end{tabular}


Anexo 2.2: Continuação

\begin{tabular}{|c|c|c|c|c|}
\hline Amostra & Município/localidade & Estado & Coordenadas & \\
\hline ARB818 & Monte Alegre de Sergipe & SE & -10.01911 & -37.56496 \\
\hline ARB833 & Monte Alegre de Sergipe & SE & -10.01911 & -37.56496 \\
\hline ARB804 & Porto da Folha & SE & -9.89791 & -37.42544 \\
\hline ARB822 & Nossa Senhora da Glória & SE & -10.01911 & -37.56496 \\
\hline ARB829 & Paulo Afonso & BA & -10.22584 & -37.42010 \\
\hline UFES-CTA1429 & Barra do Garças & MT & -15.89163 & -52.26186 \\
\hline UFES-CTA1295 & Nova Ponte & MG & -19.22538 & -47.70376 \\
\hline UFES-CTA1259 & Nova Ponte & MG & -19.22538 & -47.70376 \\
\hline UFES-CTA1241 & Crato & CE & -7.215591 & -39.40932 \\
\hline UFES-CTA1244 & Crato & CE & -7.215591 & -39.40932 \\
\hline UFES-CTA1541 & Poconé & MT & -16.27375 & -16.27375 \\
\hline UFES-CTA1534 & Poconé & MT & -16.27375 & -16.27375 \\
\hline UFES-CTA1550 & Passo do Lontra & MS & -19.57791 & -57.03681 \\
\hline UFES-CTA1547 & Passo do Lontra & MS & -19.57791 & -57.03681 \\
\hline DID1 & PARNA Chapada dos Guimarães & MT & -15.42757 & -55.83072 \\
\hline DID6 & PARNA Chapada dos Guimarães & MT & -15.42757 & -55.83072 \\
\hline DID8 & PARNA Chapada dos Guimarães & MT & -15.42757 & -55.83072 \\
\hline DID9 & PARNA Chapada dos Guimarães & MT & -15.42757 & -55.83072 \\
\hline DID11 & PARNA de Emas & GO & -18.25405 & -52.75162 \\
\hline DID12 & PARNA de Emas & GO & -18.25405 & -52.75162 \\
\hline DID13 & PARNA de Emas & GO & -18.25405 & -52.75162 \\
\hline DID14 & PARNA de Emas & GO & -18.25405 & -52.75162 \\
\hline DID15 & PARNA de Emas & GO & -18.25405 & -52.75162 \\
\hline DID17 & PARNA de Emas & GO & -18.25405 & -52.75162 \\
\hline DID29 & PARNA Grande Sertão Veredas & $\mathrm{BA} / \mathrm{MG} / \mathrm{GO}$ & -14.88291 & -45.94247 \\
\hline DID30 & PARNA Grande Sertão Veredas & $\mathrm{BA} / \mathrm{MG} / \mathrm{GO}$ & -14.88291 & -45.94247 \\
\hline DID31 & PARNA Grande Sertão Veredas & $\mathrm{BA} / \mathrm{MG} / \mathrm{GO}$ & -14.88291 & -45.94247 \\
\hline DID32 & PARNA Grande Sertão Veredas & $\mathrm{BA} / \mathrm{MG} / \mathrm{GO}$ & -14.88291 & -45.94247 \\
\hline DID33 & PARNA Grande Sertão Veredas & $\mathrm{BA} / \mathrm{MG} / \mathrm{GO}$ & -14.88291 & -45.94247 \\
\hline
\end{tabular}


Anexo 2.2: Continuação

\begin{tabular}{|c|c|c|c|c|}
\hline Amostra & Município/localidade & Estado & Coordenad & \\
\hline DID34 & PARNA Grande Sertão Veredas & BA/MG/GO & -14.88291 & -45.94247 \\
\hline DID35 & PARNA Grande Sertão Veredas & $\mathrm{BA} / \mathrm{MG} / \mathrm{GO}$ & -14.88291 & -45.94247 \\
\hline DID36 & PARNA Grande Sertão Veredas & $\mathrm{BA} / \mathrm{MG} / \mathrm{GO}$ & -14.88291 & -45.94247 \\
\hline DID37 & PARNA Grande Sertão Veredas & $\mathrm{BA} / \mathrm{MG} / \mathrm{GO}$ & -14.88291 & -45.94247 \\
\hline DID38 & PARNA Grande Sertão Veredas & $\mathrm{BA} / \mathrm{MG} / \mathrm{GO}$ & -14.88291 & -45.94247 \\
\hline DID39 & PARNA Grande Sertão Veredas & $\mathrm{BA} / \mathrm{MG} / \mathrm{GO}$ & -14.88291 & -45.94247 \\
\hline DID40 & PARNA Chapada dos Veadeiros & GO & -14.03894 & -47.62296 \\
\hline DID41 & PARNA Chapada dos Veadeiros & GO & -14.03894 & -47.62296 \\
\hline DID42 & PARNA Chapada dos Veadeiros & GO & -14.03894 & -47.62296 \\
\hline DID44 & PARNA Chapada das Mesas & MA & -7.24020 & -47.143 \\
\hline DID45 & PARNA Chapada das Mesas & MA & -7.24020 & -47.143 \\
\hline ECO3 & Nova Xavantina & MT & -14.77937 & -52.66124 \\
\hline ECO4 & Nova Xavantina & MT & -14.77937 & -52.66124 \\
\hline ECO13 & Nova Xavantina & MT & -14.77937 & -52.66124 \\
\hline ECO10 & Nova Xavantina & MT & -14.77937 & -52.66124 \\
\hline ECO18 & Nova Xavantina & MT & -14.77937 & -52.66124 \\
\hline MAR26 & Jardim Botânico, Brasília & DF & -15.89348 & -47.84998 \\
\hline MAR28 & Jardim Botânico, Brasília & DF & -15.89348 & -47.84998 \\
\hline MAR33 & EMBRAPA, Brasília & DF & & \\
\hline MAR41 & EMBRAPA, Brasília & DF & & \\
\hline MAR45 & Fazenda Água Limpa, Brasília & DF & & \\
\hline MAR46 & Fazenda Água Limpa, Brasília & DF & & \\
\hline MAR49 & Fazenda Água Limpa, Brasília & DF & & \\
\hline MCNU847 & Piranhas & GO & -16.42491 & -51.82781 \\
\hline UNB2322 & PARNA de Brasília & DF & -15.65524 & -47.96745 \\
\hline UNB2841 & PARNA Serra da Canastra & MG & -20.29740 & -46.52211 \\
\hline UNB2854 & Catalão & GO & -17.80908 & -47.74128 \\
\hline UNB2855 & Catalão & GO & -17.80908 & -47.74128 \\
\hline UNB2857 & Catalão & GO & -17.80908 & -47.74128 \\
\hline UNB2858 & Catalão & GO & -17.80908 & -47.74128 \\
\hline
\end{tabular}


Anexo 2.2: Continuação

\begin{tabular}{lllll}
\hline Amostra & Município/localidade & Estado & Coordenadas & \\
\hline UNB2859 & Catalão & GO & -17.80908 & -47.74128 \\
UNB2860 & Catalão & GO & -17.80908 & -47.74128 \\
UNB2861 & Catalão & GO & -17.80908 & -47.74128 \\
UNB2862 & Catalão & GO & -17.80908 & -47.74128 \\
UNB2863 & Catalão & GO & -17.80908 & -47.74128 \\
UNB2864 & Catalão & GO & -17.80908 & -47.74128 \\
\hline Grupos & & & & \\
externos & & DID43 & & \\
Cryptonanus sp. & & DID28 & & \\
Marmosa murina & & DID20 & & \\
Gracilinanus microtarsus & G Uarth Christoff; ARB: Caderno
\end{tabular}

Acrônimos: AC: caderno de campo de Alexandre Uarth Christoff; ARB: caderno de campo de Alexandra Bezerra; ECO: coleção do autor; UFES-CTA: coleção de tecidos animais da Universidade Federal do Espírito Santo; DID: coleção de tecidos de mamíferos do Laboratório de Genética e Biodiversidade da Universidade de Brasília; MAR: coleção de tecidos de mamíferos do Laboratório de Genética e Biodiversidade da Universidade de Brasília; MCNU: Museu de Ciências Naturais da Universidade Luterana do Brasil; UNB: coleção de mamíferos da Universidade de Brasília. 
Anexo 3.2: Sequências do gene citocromo b (cyt-b) de G. agilis obtidos do GenBank. São indicados o número de acesso, município, unidade federativa, coordenadas geográficas em graus decimais e referência dos trabalhos que geraram a sequência.

\begin{tabular}{|c|c|c|c|c|c|}
\hline \multirow{2}{*}{$\begin{array}{l}\text { Número de acesso } \\
\text { KF313923/CRB2311 }\end{array}$} & \multirow{2}{*}{$\begin{array}{l}\text { Município } \\
\text { Mimoso de Goiás }\end{array}$} & \multirow{2}{*}{$\begin{array}{l}\text { UF } \\
\text { GO }\end{array}$} & \multicolumn{2}{|c|}{ Coordenadas } & \multirow{2}{*}{$\begin{array}{l}\text { Referência } \\
\text { Faria et al. } 2013\end{array}$} \\
\hline & & & -15.0588 & -48.1620 & \\
\hline KF313924/CRB746 & Teresina de Goiás & GO & -13.6395 & -47.2533 & Faria et al. 2013 \\
\hline KF313925/CRB648 & Teresina de Goiás & GO & -13.6395 & -47.2533 & Faria et al. 2013 \\
\hline KF313926/CRB750 & Teresina de Goiás & GO & -13.6395 & -47.2533 & Faria et al. 2013 \\
\hline KF313927/CRB895 & Cavalcante & GO & -13.7980 & -47.4570 & Faria et al. 2013 \\
\hline KF313981/JAO1184 & Rio das Contas & BA & -13.5858 & -41.8136 & Faria et al. 2013 \\
\hline KF313980/JAO1177 & Rio das Contas & BA & -13.5858 & -41.8136 & Faria et al. 2013 \\
\hline KF313979/JAO1171 & Rio das Contas & $\mathrm{BA}$ & -13.5858 & -41.8136 & Faria et al. 2013 \\
\hline KF313978/LBCE3827 & Caetité & BA & -14.0648 & -42.4858 & Faria et al. 2013 \\
\hline KF313977/LBCE3801 & Caetité & $\mathrm{BA}$ & -14.0648 & -42.4858 & Faria et al. 2013 \\
\hline KF313976/LBCE3832 & Caetité & BA & -14.0648 & -42.4858 & Faria et al. 2013 \\
\hline KF313974/LBCE3817 & Caetité & BA & -14.0648 & -42.4858 & Faria et al. 2013 \\
\hline KF313974/LBCE2743 & Coronel José Dias & $\mathrm{PI}$ & -8.8090 & -42.3544 & Faria et al. 2013 \\
\hline KF313973/LBCE2736 & Coronel José Dias & $\mathrm{PI}$ & -8.8090 & -42.3544 & Faria et al. 2013 \\
\hline KF313972/LBCE1261 & Coronel José Dias & $\mathrm{PI}$ & -8.8090 & -42.3544 & Faria et al. 2013 \\
\hline KF313971/LBCE2758 & Coronel José Dias & $\mathrm{PI}$ & -8.8090 & -42.3544 & Faria et al. 2013 \\
\hline KF313970/LBCE1240 & João Costa & $\mathrm{Pl}$ & -8.4848 & -42.4724 & Faria et al. 2013 \\
\hline KF313969/LBCE5265 & Jaguaruana & CE & -4.8361 & -37.7815 & Faria et al. 2013 \\
\hline KF313968/LBCE5263 & Jaguaruana & CE & -4.8361 & -37.7815 & Faria et al. 2013 \\
\hline KF313967/LBCE5254 & Jaguaruana & CE & -4.8361 & -37.7815 & Faria et al. 2013 \\
\hline KF313966/AP625 & Buíque & PE & -8.6210 & -37.1572 & Faria et al. 2013 \\
\hline KF313965/AP622 & Buíque & PE & -8.6210 & -37.1572 & Faria et al. 2013 \\
\hline KF313964/AP614 & Buíque & PE & -8.6210 & -37.1572 & Faria et al. 2013 \\
\hline KF313963/CRB1670 & Jaborandi & BA & -14.0716 & -45.4498 & Faria et al. 2013 \\
\hline KF313962/CRB1644 & Jaborandi & BA & -14.0716 & -45.4498 & Faria et al. 2013 \\
\hline KF313961/CRB1606 & Jaborandi & $\mathrm{BA}$ & -14.0716 & -45.4498 & Faria et al. 2013 \\
\hline KF313960/CRB1571 & Jaborandi & BA & -14.0716 & -45.4498 & Faria et al. 2013 \\
\hline KF313959/MCNM2189 & Brasilândia de Minas & MG & -17.0003 & -46.0085 & Faria et al. 2013 \\
\hline
\end{tabular}


Anexo 3.2: Continuação

\begin{tabular}{|c|c|c|c|c|c|}
\hline \multirow{2}{*}{$\begin{array}{l}\text { Número de acesso } \\
\text { KF313958/MCNM2243 }\end{array}$} & \multirow{2}{*}{$\begin{array}{l}\text { Município } \\
\text { João Pinherio }\end{array}$} & \multirow{2}{*}{$\begin{array}{l}\text { UF } \\
\text { MG }\end{array}$} & \multicolumn{2}{|c|}{ Coordenadas } & \multirow{2}{*}{$\begin{array}{l}\text { Referência } \\
\text { Faria et al. } 2013\end{array}$} \\
\hline & & & -17.7405 & -46.1741 & \\
\hline KF313957/LBCE4888 & Aquidauana & MS & -20.4670 & -55.7872 & Faria et al. 2013 \\
\hline KF313956/LBCE5667 & Corumbá & MS & -19.0081 & -57.6515 & Faria et al. 2013 \\
\hline KF313955/LBCE5666 & Corumbá & MS & -19.0081 & -57.6515 & Faria et al. 2013 \\
\hline KF313954/LBCE5665 & Corumbá & MS & -19.0081 & -57.6515 & Faria et al. 2013 \\
\hline KF313953/LBCE11949 & Cassilândia & MS & -19.1097 & -51.7365 & Faria et al. 2013 \\
\hline KF313952/LBCE8774 & Luziânia & GO & -16.2514 & -47.9177 & Faria et al. 2013 \\
\hline KF313951/LBCE7514 & Luziânia & GO & -16.2514 & -47.9177 & Faria et al. 2013 \\
\hline KF313950/LBCE7500 & Luziânia & GO & -16.2514 & -47.9177 & Faria et al. 2013 \\
\hline KF313949/LBCE9410 & Aporé & GO & -18.9611 & -51.9236 & Faria et al. 2013 \\
\hline GKF313948/LBCE9435 & Aporé & GO & -18.9611 & -51.9236 & Faria et al. 2013 \\
\hline KF313947/LBCE9413 & Aporé & GO & -18.9611 & -51.9236 & Faria et al. 2013 \\
\hline KF313946/LBCE9415 & Aporé & GO & -18.9611 & -51.9236 & Faria et al. 2013 \\
\hline KF313945/LBCE9430 & Aporé & GO & -18.9611 & -51.9236 & Faria et al. 2013 \\
\hline KF313944/LBCE11947 & Aporé & GO & -18.9611 & -51.9236 & Faria et al. 2013 \\
\hline KF313943/LBCE9474 & Anápolis & GO & -16.3285 & -48.9534 & Faria et al. 2013 \\
\hline KF313942/LBCE9469 & Anápolis & GO & -16.3285 & -48.9534 & Faria et al. 2013 \\
\hline kf313941/LBCE11994 & São Domingos & GO & -13.4004 & -46.3221 & Faria et al. 2013 \\
\hline kf313940/LBCE11996 & São Domingos & GO & -13.4004 & -46.3221 & Faria et al. 2013 \\
\hline KF313939/LBCE11997 & São Domingos & GO & -13.4004 & -46.3221 & Faria et al. 2013 \\
\hline KF313938/CRB954 & Cavalcante & GO & -13.7980 & -47.4570 & Faria et al. 2013 \\
\hline KF313937/CRB1006 & Cavalcante & GO & -13.7980 & -47.4570 & Faria et al. 2013 \\
\hline KF313936/CRB982 & Cavalcante & GO & -13.7980 & -47.4570 & Faria et al. 2013 \\
\hline KF313935/CRB978 & Cavalcante & GO & -13.7980 & -47.4570 & Faria et al. 2013 \\
\hline KF313934/CRB1001 & Cavalcante & GO & -13.7980 & -47.4570 & Faria et al. 2013 \\
\hline KF313933/CRB977 & Cavalcante & GO & -13.7980 & -47.4570 & Faria et al. 2013 \\
\hline KF313932/CRB974 & Cavalcante & GO & -13.7980 & -47.4570 & Faria et al. 2013 \\
\hline KF313931/CRB952 & Cavalcante & GO & -13.7980 & -47.4570 & Faria et al. 2013 \\
\hline KF313930/CRB901 & Cavalcante & GO & -13.7980 & -47.4570 & Faria et al. 2013 \\
\hline KF313929/CRB1009 & Cavalcante & GO & -13.7980 & -47.4570 & Faria et al. 2013 \\
\hline KF313928/CRB1007 & Cavalcante & GO & -13.7980 & -47.4570 & Faria et al. 2013 \\
\hline
\end{tabular}


Anexo 3.2: Continuação

\begin{tabular}{|c|c|c|c|c|c|}
\hline \multirow{2}{*}{$\begin{array}{l}\text { Número de acesso } \\
\text { JF281024/LPC317 }\end{array}$} & \multirow{2}{*}{$\begin{array}{l}\text { Município } \\
\text { Nova Ponte }\end{array}$} & \multirow{2}{*}{$\begin{array}{l}\text { UF } \\
\text { MG }\end{array}$} & \multicolumn{2}{|c|}{ Coordenadas } & \multirow{2}{*}{$\begin{array}{l}\text { Referência } \\
\text { Rocha et al. } 2015\end{array}$} \\
\hline & & & -19.2253 & -47.7037 & \\
\hline JF281023/RGR482 & Lagoa da Confusão & TO & -10.9201 & -50.1832 & Rocha et al. 2015 \\
\hline JF281022/RGR446 & Lagoa da Confusão & TO & -10.9201 & -50.1832 & Rocha et al. 2015 \\
\hline JF281021/RGR427 & Lagoa da Confusão & TO & -10.9201 & -50.1832 & Rocha et al. 2015 \\
\hline JF281019/LPC283 & Crato & CE & -7.2155 & -39.4093 & Rocha et al. 2015 \\
\hline JF281018/LPC243 & Crato & CE & -7.2155 & -39.4093 & Rocha et al. 2015 \\
\hline JF281017/LPC251 & Crato & CE & -7.2155 & -39.4093 & Rocha et al. 2015 \\
\hline JF281016/LPC249 & Crato & CE & -7.2155 & -39.4093 & Rocha et al. 2015 \\
\hline JF281015/LPC270 & Crato & CE & -7.2155 & -39.4093 & Rocha et al. 2015 \\
\hline JF281014/RGR480 & Lagoa da Confusão & TO & -10.9201 & -50.1832 & Rocha et al. 2015 \\
\hline JF281013/RGR95 & Pium & TO & -10.4427 & -49.1798 & Rocha et al. 2015 \\
\hline JF281012/RGR405 & Lagoa da Confusão & TO & -10.9201 & -50.1832 & Rocha et al. 2015 \\
\hline JF281011/RGR406 & Lagoa da Confusão & TO & -10.9201 & -50.1832 & Rocha et al. 2015 \\
\hline JF281010/RGR426 & Lagoa da Confusão & TO & -10.9201 & -50.1832 & Rocha et al. 2015 \\
\hline JF281009/LPC589 & Poconé & MT & -16.2737 & -56.6265 & Rocha et al. 2015 \\
\hline JF281008/LPC297 & Nova Ponte & MG & -19.2253 & -47.7037 & Rocha et al. 2015 \\
\hline JF281007/LPC380 & Nova Ponte & MG & -19.2253 & -47.7037 & Rocha et al. 2015 \\
\hline KM066022/MZUSP35188 & Parna Pantanal & MT & -17.6673 & -57.4689 & Semedo et al. 2015 \\
\hline KM066021/MZUSP35190 & Parna Pantanal & MT & -17.6673 & -57.4689 & Semedo et al. 2015 \\
\hline KM066020/MZUSP35191 & Parna Pantanal & MT & -17.6673 & -57.4689 & Semedo et al. 2015 \\
\hline KM066018/MZUSP35186 & Parna Pantanal & MT & -17.6673 & -57.4689 & Semedo et al. 2015 \\
\hline KM066017/MZUSP5187 & Parna Pantanal & MT & -17.6673 & -57.4689 & Semedo et al. 2015 \\
\hline KM066016/MZUSP35192 & Parna Pantanal & MT & -17.6673 & -57.4689 & Semedo et al. 2015 \\
\hline HQ622160/UFMG2498 & Barra do Garças & MT & -15.8916 & -52.2618 & Loss et al. 2011 \\
\hline HQ622159/UFMG2497 & Poconé & MT & -16.2737 & -56.6265 & Loss et al. 2011 \\
\hline HQ622158/UFMG2500 & Passo do Lontra & MG & -19.5779 & -57.0368 & Loss et al. 2011 \\
\hline HQ622157/UFMG2515 & Nova Ponte & MG & -19.2253 & -47.7037 & Loss et al. 2011 \\
\hline HQ622156/UHECO4722 & Caldas Novas & GO & -17.7445 & -48.6250 & Loss et al. 2011 \\
\hline HQ622155/UFMG2495 & Coronel Murta & MG & -16.6153 & -42.1843 & Loss et al. 2011 \\
\hline HQ622154/UFMG2433 & Bocaiuva & MG & -17.1114 & -43.820 & Loss et al. 2011 \\
\hline HQ622149/UFMG2504 & Chapada do Araripe & CE & -7.3875 & -40.2161 & Loss et al. 2011 \\
\hline
\end{tabular}


Anexo 3.2: Continuação

\begin{tabular}{lll}
\hline Grupos externos & $\begin{array}{l}\text { Número de } \\
\text { acesso }\end{array}$ & Referência \\
\hline Gracilinanus peruanus & KM66033/INPA6741 & Semedo et al. 2015 \\
Gracilinanus peruanus & KM66029/INPA6740 & Semedo et al. 2015 \\
Gracilinanus peruanus & KM66028/INPA6739 & Semedo et al. 2015 \\
Gracilinanus peruanus & KM66030/INPA6738 & Semedo et al. 2015 \\
Gracilinanus peruanus & KM66032/INPA6737 & Semedo et al. 2015 \\
Gracilinanus peruanus & KM66031/INPA6736 & Semedo et al. 2015 \\
Gracilinanus microtarsus & KT952260/LPC820 & Leite et al. 2016 \\
Gracilinanus microtarsus & KT952261/LPC821 & Leite et al. 2016 \\
Gracilinanus microtarsus & KT952262/LPC822 & Leite et al. 2016 \\
Gracilinanus microtarsus & KT952241/LPC915 & Leite et al. 2016 \\
Gracilinanus microtarsus & KT952268/YL428 & Leite et al. 2016 \\
Gracilinanus microtarsus & KT952242/CTA1051 & Leite et al. 2016 \\
\hline
\end{tabular}

Anexo 4.2: Nome e sequências dos iniciadores (primers) utilizados no estudo, e as referências de onde foram obtidos.

\begin{tabular}{lll}
\hline Primer & Sequência & Referência \\
\hline PPIC-F1 & 5'- CCCAAGACTGTGGAGAATTTC & $\begin{array}{l}\text { Giarla \& Jansa, } \\
2014 \\
\text { Giarla \& Jansa, } \\
2014\end{array}$ \\
PPIC-R1 & 5'- CAACAGTAAAGTCTCCACCTTGAA & $\begin{array}{l}\text { Giarla \& Jansa, } \\
2014\end{array}$ \\
P4HB-F1 & 5'- GCAGTTAAGGTTCACAGTTTCCCT & Giarla \& Jansa, \\
& & 2014 \\
P4HB-R1 & 5'- ATCTTGTCCACCACTCTCCAG & Giarla, 2013 \\
OGT-F & 5'-AAATCATTTCATCGACCTTTCTCAG & \\
& & Giarla, 2013 \\
OGT-R & 5'-ATTCCCTGTAATGGAAAAGCAGC & Smith \& Patton, \\
& 5'- & 1993 \\
MVZ05 & CGAAGCTTGATATGAAAAACCATCGTTG & Smith \& Patton, \\
MVZ16 & 5'- & 1993 \\
\hline
\end{tabular}


Capítulo 3

Expansão demográfica de Calomys tener (Rodentia, Cricetidae) durante o Quaternário tardio no Cerrado: respostas ao efeito do fogo e ocupação humana pré-histórica 


\section{Introdução}

A presença de fogo, tanto de origem natural como provocado pelo homem, em paisagens naturais tem implicações diretas na diversificação e evolução da biota (Bowman et al. 2011). No Cerrado do Brasil central as queimadas são fatores determinantes para a alteração de fitofisionomias, influenciando diretamente a densidade de componentes arbóreos, arbustivos e herbáceos (Cole 1960; Coutinho 1982; Eiten 1972). A presença de fogo no Cerrado é histórica, sendo reconhecida desde o final do Pleistoceno (Ledru 2002) e início do Holoceno (Ledru et al. 1998), promovida tanto por indígenas pré-históricos (Barbosa \& Schimtz 2008) como atuais (Mistry et al. 2005).

Estudos ecológicos tem demonstrado diferentes resultados sobre o efeito do fogo em comunidades de vertebrados e invertebrados no Cerrado. Por exemplo, comunidades de lagartos parecem sofrer nenhuma (Costa 2011) ou pouca (Pantoja 2007) influência do fogo na composição e riqueza de espécies. Por outro lado, comunidades de aranhas (Freire 2010) e pequenos mamíferos (Briani et al. 2004; Henriques et al. 2007; Vieira \& Marinho-Filho 1998) parecem ser mais sensíveis quando seus habitats são alterados pela presença de fogo. Apesar de haver um número razoável de estudos ecológicos sobre o efeito de queimadas sobre comunidades naturais do Cerrado, estudos históricos de genética demográfica e filogeografia parecem não dar atenção ao efeito do fogo sobre a estruturação geográfica, diversificação genética e evolução de diferentes grupos biológicos (e.g. Guarnizo et al. 2016; Nascimento et al. 2011, 2012). Sob uma perspectiva temporal, é possível supor que a presença do homem pré-histórico e sua prática de produzir fogo há cerca de 13.000/11.000 anos atrás (Barbosa \& Schimtz 2008; Bueno et al. 2013), bem como a existência do Cerrado e registros de fogo há cerca de 32.000 anos atrás (Ledru 2002), também seriam fatores que explicitamente exerceriam pressão sobre a biota e poderiam levar ao surgimento de diferentes tendências históricas de diversificação genética e evolução dos organismos.

Calomys tener é um roedor cricétido amplamente distribuído em áreas de campo do Cerrado (Bonvicino et al. 2008) e áreas alteradas de biomas adjacentes, como Mata Atlântica. Este roedor pertence a tribo Phyllotini que por sua vez compreende gêneros e espécies estritamente relacionados com habitats de formações abertas, como savanas e campo (Salazar-Bravo et al. 2013). Estudos ecológicos 
indicam que populações de $C$. tener aumentam sua abundância em áreas de campo e Cerrados que sofreram queimadas recentes (Vieira \& Marinho-Filho 1998) ao passo que diminuem em densidade em áreas com sucessão ecológica mais avançada após o evento de queimadas (Briani et al. 2004; Henriques et al. 2007). Além disso, observações pessoais sugerem que em levantamento de espécies de pequenos mamíferos, Calomys é frequentemente capturado em áreas recentemente queimadas e alteradas por ação antrópica (Machado, Rocha e Marinho-Filho, observações pessoais). Neste contexto, C. tener é um organismo interessante para se avaliar os efeitos ecológicos e históricos da presença de fogo no Cerrado, bem como sua relação com a ocupação do homem pré-histórico e suas possíveis influências sobre a biota do Cerrado

O objetivo do presente estudo foi aplicar métodos filogenéticos, filogeográficos coalescentes e ferramentas de computação bayesiana aproximada ( $A B C$ - Beaumont $e t$ al. 2002) para testar se a ocupação humana e a ocorrência de fogo no Cerrado tiveram papeis determinantes para a diversificação de C. tener. Explicitamente serão testadas as hipóteses de que (i) a presença de fogo e um ambiente de Cerrado (similar com ao atual) há cerca de 32.000 anos atrás permitiu a expansão demográfica de $C$. tener; e (ii) a ocupação de indígenas pré-históricos e a utilização do fogo por volta de 12.000 anos atrás foi um fator que acelerou a expansão demográfica de C. tener. Como hipóteses nulas, previmos que populações ancestrais de $C$. tener mantiveram-se constantes ao longo do tempo, e/ou outros eventos como aquecimento da temperatura e aumento de úmidade (como ocorrido no último máximo interglacial) afetaram a demografia de C. tener.

\section{Materiais e métodos}

Amostras, procedimentos de laboratório e tratamento das sequências

Foram utilizados 46 tecidos de espécimes de C. tener provenientes de 24 localidades inseridas no bioma Cerrado (Figura 1.3). Estas amostras foram obtidas a partir de expedições a campo realizadas durantes os anos de 2014 e 2015 e de doações de colegas pesquisadores e coleções científicas de outras instituições do Brasil. Uma lista com o número de tombamento e/ou número de coleta de campo, localidade de coleta e coordenadas geográficas é fornecida no anexo 1.3. Além do conjunto de 
dados gerados a partir dessas amostras, foram obtidas dez sequências do gene cyt-b de espécimes de $C$. tener depositadas no GenBank (plataforma online e repositório de dados moleculares) (Anexo 1.3). Os táxons Calomys expulsus, C. tocantinsi e $C$. callosus foram utilizados como grupos externos para as reconstruções filogenéticas (Anexo 1.3). Esta amostragem contempla espécies do mesmo clado e de outros mais distantes em relação a $C$. tener.

O DNA das amostras foi extraído utilizando o método de fenol-clorofórmio e a qualidade das extrações foi avaliada através de uma eletroforese em gel de agarose $1,5 \%$. Foram amplificadas 700 pares de bases $(\mathrm{pb})$ do gene mitocondrial citocromo $b$ (cyt-b; Smith \& Patton, 1993) e dois introns nucleares: intron 7 do beta fibrinogênio (Bfib; 640 pb; Wickliffe et al. 2003) e intron 2 do gene álcool desidrogenase 1 (ADH; $\sim 520 \mathrm{pb}$; Amman et al. 2006). As sequências dos primers utilizados e respectivas referências são apresentadas no anexo 2.3.

As reações de amplificação (Reação em Cadeia da Polimerase - PCR) dos marcadores selecionados foram realizadas em um volume final de $15 \mu$ utilizando-se 1,5 $\mathrm{mM}$ de $\mathrm{MgCl}_{2}, 0,2 \mathrm{mM}$ de dNTPs, $0,2 \mu \mathrm{M}$ de cada primer, 1,5U de Taq DNA Polimerase (Invitrogen) e $30 \mathrm{ng}$ de DNA, e ciclos de temperatura compostos por um passo de desnaturação inicial a $95{ }^{\circ} \mathrm{C}$ por 5 min, seguidos por 35 ciclos de $95{ }^{\circ} \mathrm{C}$ por $45 \mathrm{seg}, 48-56{ }^{\circ} \mathrm{C}$ (conforme a temperatura de anelamento de cada primer) por $45 \mathrm{seg} \mathrm{e}$ $72{ }^{\circ} \mathrm{C}$ por $45 \mathrm{seg}$, finalizando com uma etapa de extensão à $72{ }^{\circ} \mathrm{C}$ por $10 \mathrm{~min}$. Pequenas adequações foram realizadas neste protocolo padrão para algumas amostras e espécies, conforme a necessidade.

Os produtos resultantes da PCR foram purificados com enzimas ExoSap (USB Corporation) e sequenciados pelo método Sanger na empresa Macrogen Inc. (Seoul, Korea) e no Centro de Genômica do Distrito Federal, localizado na Universidade Católica de Brasília. As sequências foram editadas no programa GENEIOUS 6.1 (Biomatters) e a fase gamética dos marcadores nucleares estimada pelo algoritmo PHASE (Stephens et al. 2001) implementado no programa DNASP 5.10 (Librado \& Rozas 2009). 


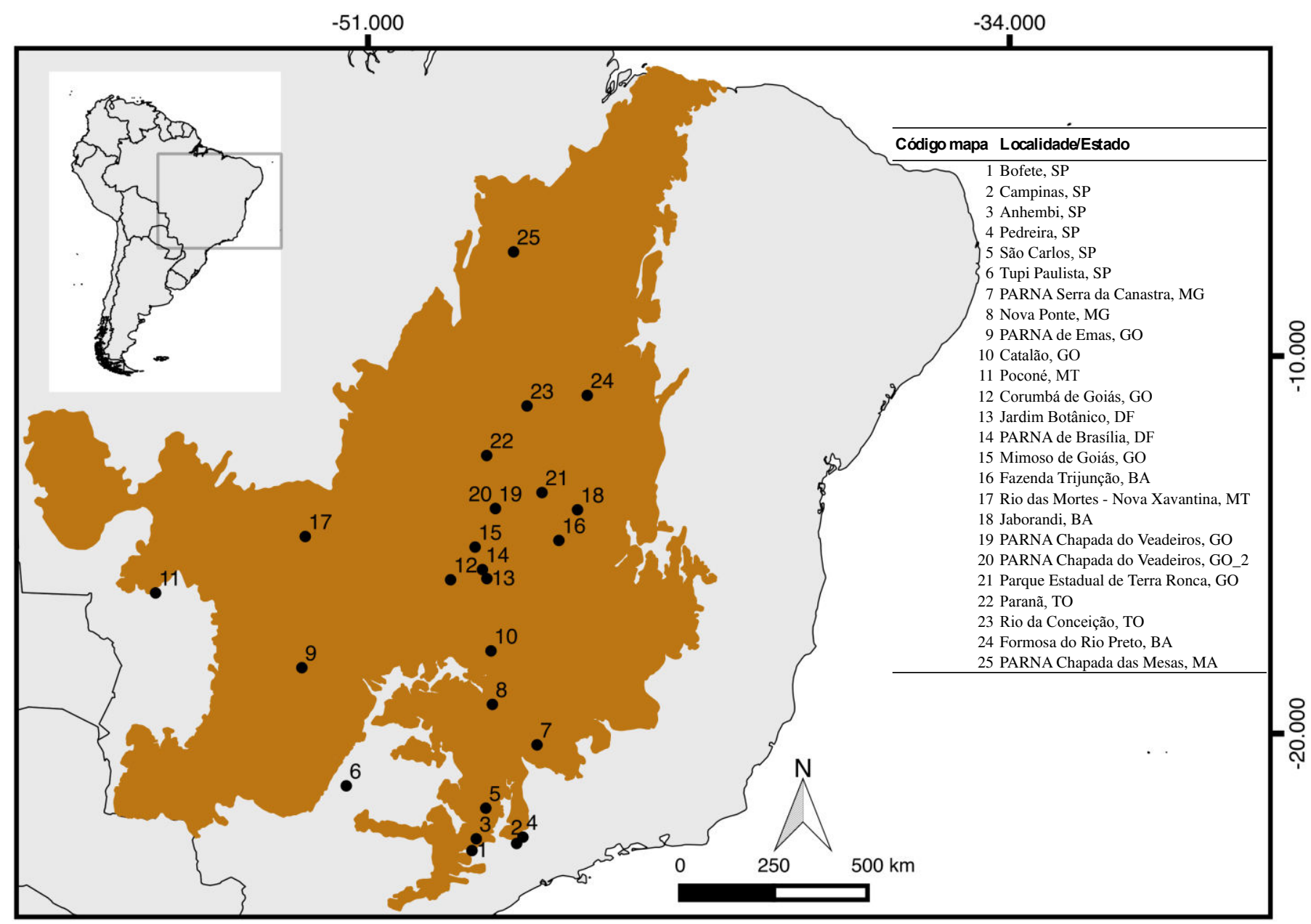

Figura 1.3: Mapa destacando a região do Cerrado e localidades de coleta de espécimes de Calomys tener utilizados nas análises. 
Alinhamento das sequências e determinação dos modelos de evolução

O alinhamento foi feito utilizando o algoritmo Muscle (Edgar 2004) e implementado no programa MEGA V. 5 (Tamura et al. 2011). Modelos de evolução nucleotídica de cada marcador molecular foram estimados no programa jModelTest 2 (Darriba et al. 2012) utilizando o critério de informação de Akaike. Com base nos scores de máxima verossimilhança, os modelos mais ajustados aos conjuntos de dados foram HKY (Hasegawa et al. 1985) com distribuição gamma (G) para cyt-b e HKY com proporção de sítios invariáveis estimados (I) e distribuição gamma (G) para Bfib e ADH.

\section{Agrupamentos populacionais e árvores de gene}

Para verificar se existem agrupamentos populacionais com estruturação genética foi conduzida uma análise de agrupamentos genéticos no programa Bayesian modelbased approach- BAPS v 6 (http://www.helsinki.fi/bsg/software/BAPS/) utilizando o algoritmo clustering with linked loci (Corander et al. 2008). Foi utilizado um vetor como número mínimo de $K$ (número de populações) de 111112222233333 , indicando que foram executadas 12 rodadas entre quatro réplicas de valores de $K$ distintos.

A relação entre os haplótipos dos conjuntos de dados mitocondrial e nucleares foi inferida através da construção de redes de haplótipos. Para isso foi utilizado o algoritmo median-joining (Bandelt et al. 1999) implementado no programa POPART 1.7 (Leigh \& Bryant 2015).

Análises filogenéticas sob uma abordagem bayesiana foram implementadas para cada conjunto de dados separadamente (cyt-b, Bfib e ADH). Estas análises foram realizadas numa perspectiva exploratória, de forma a encontrar agrupamentos filogenéticos que indiquem estruturação genética e geográfica. Para isso utilizou-se o programa MrBayes (Huelsenbeck \& Ronquist 2001) versão 3.2 .2 (disponível em http://mrbayes.sourceforge.net). Os resultados das estimativas de modelos de evolução nucleotídicas provenientes do jModelTest2 foram utilizados como priors nas inferências bayesianas. Valores de frequência de bases e taxas de substituição nucleotídica foram ajustados como valores iniciais em uma distribuição Dirichlet, enquanto parâmetros de gamma shape e proporção de sítios invariáveis foram ajustados como fixos. Foram implementadas duas cadeias de Markov Chain Monte Carlo (MCMC) com 10 milhões de gerações cada e amostragens a cada 1000 
gerações. O programa TRACER v1.3 (Rambaut \& Drummond 2007) foi usado para verificar a convergência dos valores de máxima verossimilhança e valores de tamanho efetivo das amostragens $(E S S>200)$. Ao final, $25 \%$ das árvores amostradas foram descartadas como "burn-in” e um filograma foi construído utilizando apenas nós retidos em no mínimo $50 \%$ das amostragens.

\section{Árvore de espécies, datação molecular e inferências demográficas}

Uma estimativa de árvore de espécies utilizando os três marcadores genéticos foi conduzida no programa BEAST 2 (Bouckaert et al. 2014) com o algoritmo do pacote *BEAST (Heled \& Drummond 2010) e utilizando como grupos externos as espécies $C$. tocantinsi e $C$. expulsus. Uma taxa de mutação fixa de $2 \%$ a cada um milhão de anos foi associada ao gene cyt-b utilizando relógio molecular estrito. Esta taxa de mutação é estimada como uma média para o genoma mitocondrial de várias linhagens de mamíferos (Kumar \& Subramanian 2002) e utilizada em outros trabalhos de evolução e biogeografia de pequenos mamíferos neotropicais (e.g. Gutiérrez et al. 2014). Para os demais genes também foi utilizado o relógio molecular estrito porém permitindo uma estimativa de suas taxas de mutação. Utilizou-se um modelo de evolução nucleotídica para cada partição (sequências de cada gene) de acordo com os modelos ótimos estimados no programa jModelTest. A árvore de espécies foi estimada com tamanho de população linear ao longo do tempo, utilizando o prior coalescent constant population e a taxa de mutação de cada gene (menos cyt-b) estimada a partir de uma distribuição log-normal com média 1.0 e desvio padrão 1.25. Demais parâmetros foram mantidos no default do programa seguindo as recomendações constantes em seu manual. Esta análise foi ajustada para 100.000.000 de simulações de MCMC com amostragens a cada 10.000 gerações. A convergência das amostragens e valores de ESS foram visualizada no programa TRACER v1.3 (Rambaut \& Drummond 2007). Foram implementadas duas corridas desta análise a fim de verificar a convergência dos resultados. Os arquivos das corridas independentes (arquivos .log) foram combinados no programa LogCombiner e sumarizadas no programa TreeAnotator, onde 20\% das primeiras árvores amostradas foram descartadas como "burn-in".

Para se verificar sinais de alterações demográficas ao longo do tempo foram utilizadas as estatísticas $D$ de Tajima (Tajima 1989) e $R_{2}$ de Ramos-Onsins e Rozas (Ramos-Onsins \& Rozas 2002), que testam desvios da neutralidade com base na 
frequências de mutações, e $F s$ de Fu (Fu 1997) com base na frequência de haplótipos. Estas estatísticas foram estimadas no programa DNASP v5.10 (Librado \& Rozas 2009) em simulações coalescentes de 10.000 replicações para determinar valores de probabilidade $(P<0,05$ considerado significativo) de cada estatística. Além disso, a história demográfica de $C$. tener também foi investigada utilizando a análise Bayesian Skylines Plots (BSP) implementada no programa BEAST 2. Para esta análise foram utilizadas apenas as sequências de cyt-b, sendo que a taxa de mutação, modelos de evolução e os priors utilizados foram os mesmos daqueles utilizados na inferência da árvore de espécies. Esta análise foi implementada com 100.000.000 de simulações de MCMC com amostragens a cada 10.000 gerações, e a convergência entre as cadeias e valores de ESS foram verificadas no programa TRACER v1.3, que também foi utilizado para construir os gráficos BSPs.

Modelos demográficos e cálculos bayesianos aproximados $(A B C)$

Cinco modelos demográficos foram testados (Figura 2.3) no programa DIYABC (Cornuet et al. 2014), que infere processos demográficos sob uma perspectiva de cálculos bayesianos aproximados (Beaumont et al. 2002). Os dois primeiros modelos consideram populações de $C$. tener tanto grande como pequena e constantes ao longo do tempo. Outros dois modelos foram gerados considerando crescimento demográfico no começo do Holoceno (12,000 anos atrás), no mesmo tempo em que há os primeiros registros do estabelecimento humano na região do Cerrado (Barbosa \& Schimtz 2008); e crescimento demográfico mais antigo $(32,000$ anos atrás), de acordo com registros palinológicos de expansão do Cerrado e presença de fogo (Ledru et al. 2002). O último cenário, um modelo prevendo crescimento demográfico de $C$. tener num clima mais quente e úmido durante o último máximo interglacial $(L I G)(150,000$ anos atrás) foi gerado como hipótese alternativa aos modelos 1 e 2 . Sequências de todos marcadores foram utilizadas, implementando como priors os modelos indicados pelo jModeltest. Todos os parâmetros disponíveis de sumário estatístico foram selecionados e três milhões de simulações foram geradas para cada modelo. As probabilidades posteriores dos parâmetros (valores do sumário estatístico) foram estimadas de acordo com o algoritmo de regressão linear logística indicando quais cenários demográficos se ajustam melhor ao conjunto de dados. 


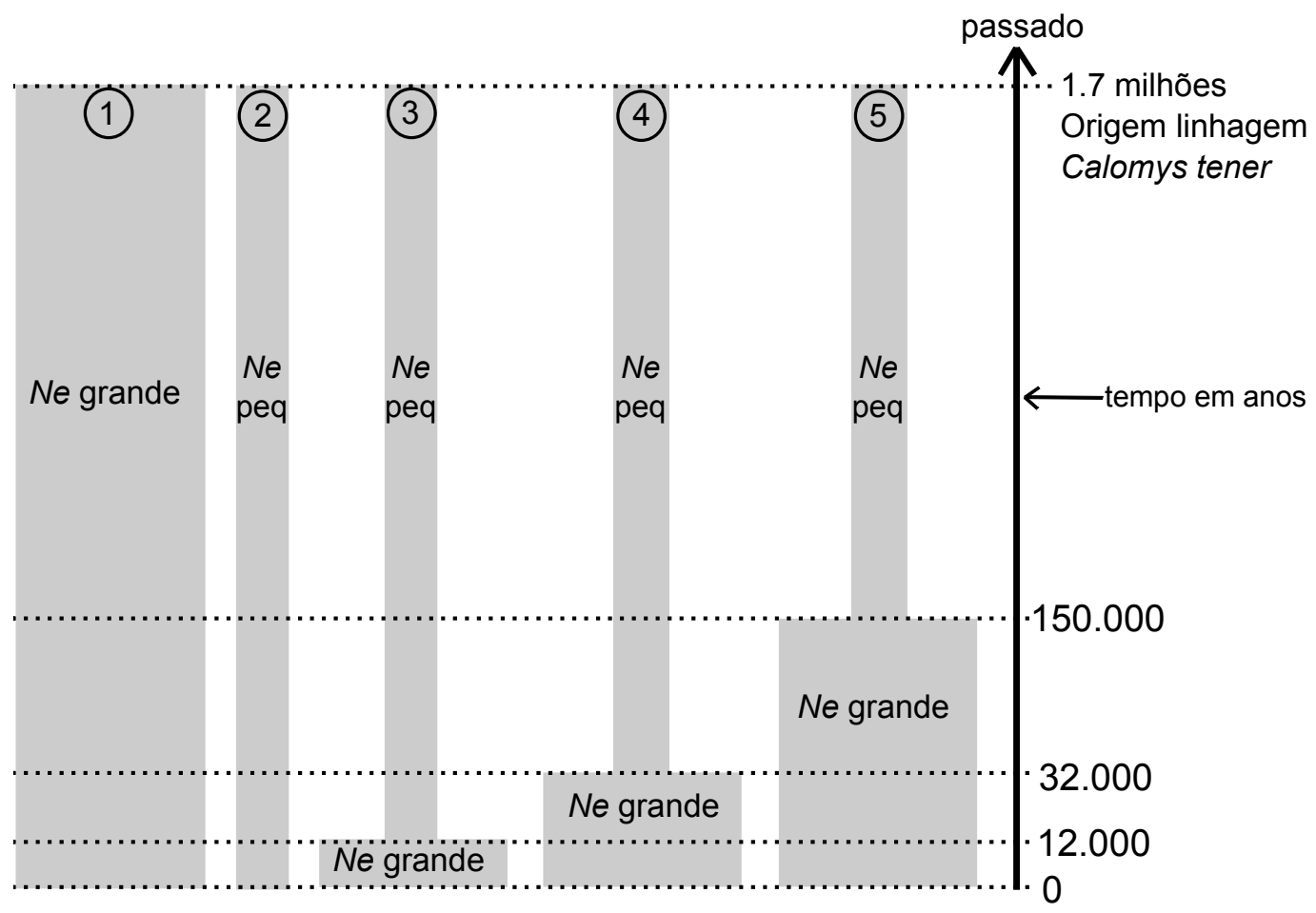

Figura 2.3: Modelos demográficos históricos de populações de $C$. tener testados no programa DIYABC. 1) população grande sem alteração demográfica ao longo do tempo; 2) população pequena sem alteração demográfica; 3) expansão demográfica no começo do Holoceno coincidindo com ocupação humana e registro de fogo no Cerrado - clima seco; 4) expansão demográfica há 32.000 anos atrás devido a existência de um Cerrado antigo frequentemente atingido por fogo - clima seco; 5) expansão demográfica a partir do último máximo interglacial, modelo alternativo clima quente e úmido. $\mathrm{Ne}=$ tamanho da população efetiva. Tempo fora de escala. 


\section{Resultados}

A análise de estruturação genética implementada no programa BAPS utilizando 56 sequências de cyt-b resultou na estimativa de apenas um conjunto genético, abrangendo todas as sequências de C. tener.

As redes de haplótipos (Figura 3.3) construídas com base nos genes cyt-b e $\mathrm{ADH}$ demonstraram baixo número de haplótipos e sem uma estruturação geográfica evidente. A rede de haplótipo com base em dados do Bfib demonstrou maior número de haplótipos, porém igualmente sem estruturação geográfica evidente.

As análises filogenéticas com base nas 56 sequências do gene cyt-b de C. tener indicou monofiletismo da espécie com alta probabilidade posterior $(\mathrm{pp}=1)$ (Figura 4.3). A filogenia com base em sequências do intron $\mathrm{ADH}$ também indicou alta probabilidade para o monofiletismo de $C$. tener, enquanto que a árvore resultante da análise do Bfib demonstrou baixa probabilidade. Todas as análises demonstraram baixa resolução dentro do clado que abrange os espécimes de C. tener, resultando em politomias.

A análise Bayesian Skyline Plots com base em sequência do gene cyt-b indicou crescimento demográfico de C. tener a partir de 200.000 anos atrás (Figura 5.3), enquanto que todos os testes estatísticos indicaram desvios do modelo neutro de populações para os marcadores cyt-b e $\mathrm{ADH}$ com valor de probabilidade significativos (Tabela 1.3). A árvore de espécies e datação molecular estimou a origem da linhagem de $C$. tener em torno de 1,7 milhões de anos atrás (Figura 6.3). Os cálculos bayesianos aproximados implementados no DIYABC indicaram cenários em épocas com presença de fogo e ocupação humana (modelos 3 e 4, 77\% de explicação em conjunto) (Figura 7.3) como melhores explicações para o processo de expansão demográfica de $C$. tener. Dentre os dois modelos, o quarto modelo foi indicado como cenário mais provável, $41 \%$ de explicação, entre os cinco modelos testados. O modelo de número 3 apresentou $36 \%$ de probabilidade posterior para explicar a expansão demográfica de $C$. tener. 
B

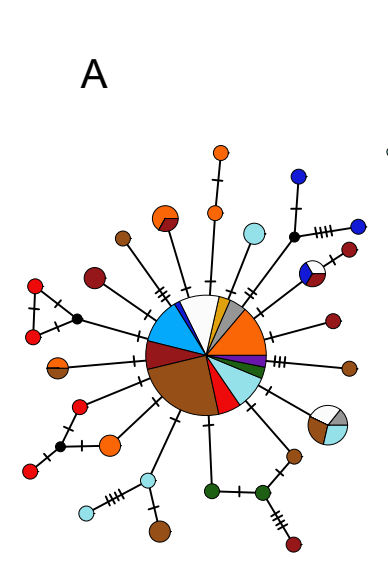

C

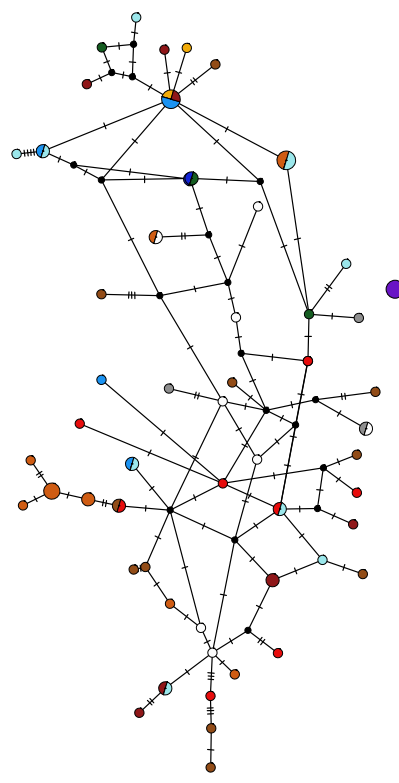

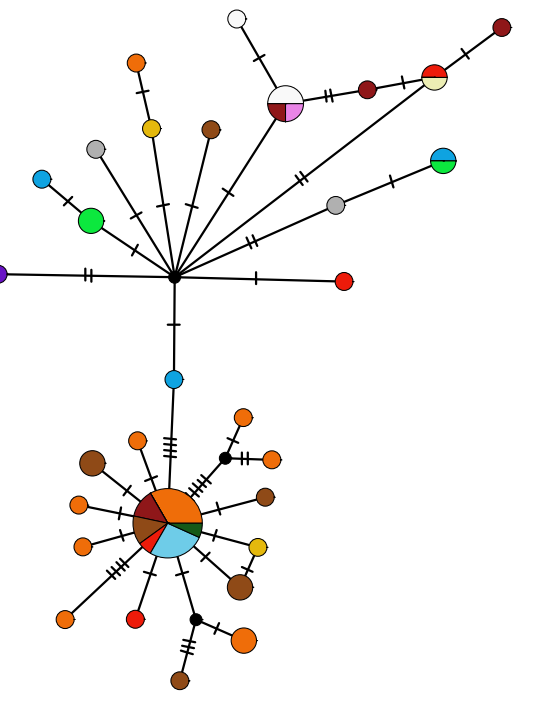

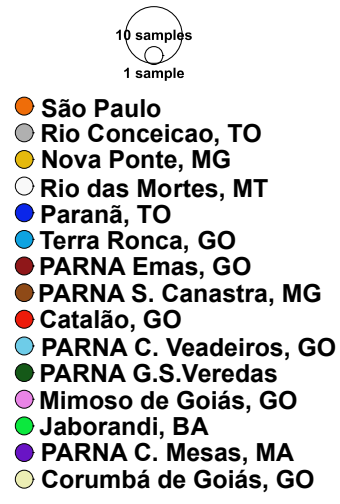

PARNA C. Mesas, MA

Figura 3.3: Redes de haplótipos com base nos marcadores ADH (A), Bfib (B) e cyt-b (C). Cada círculo representa um haplótipo. Quanto maior o tamanho do círculo maior o número de amostras apresentando o mesmo haplótipo. Cores representam localidades de coleta de acordo com a legenda a direita. Traços nos braços que ligam haplótipos representam números de mutações 


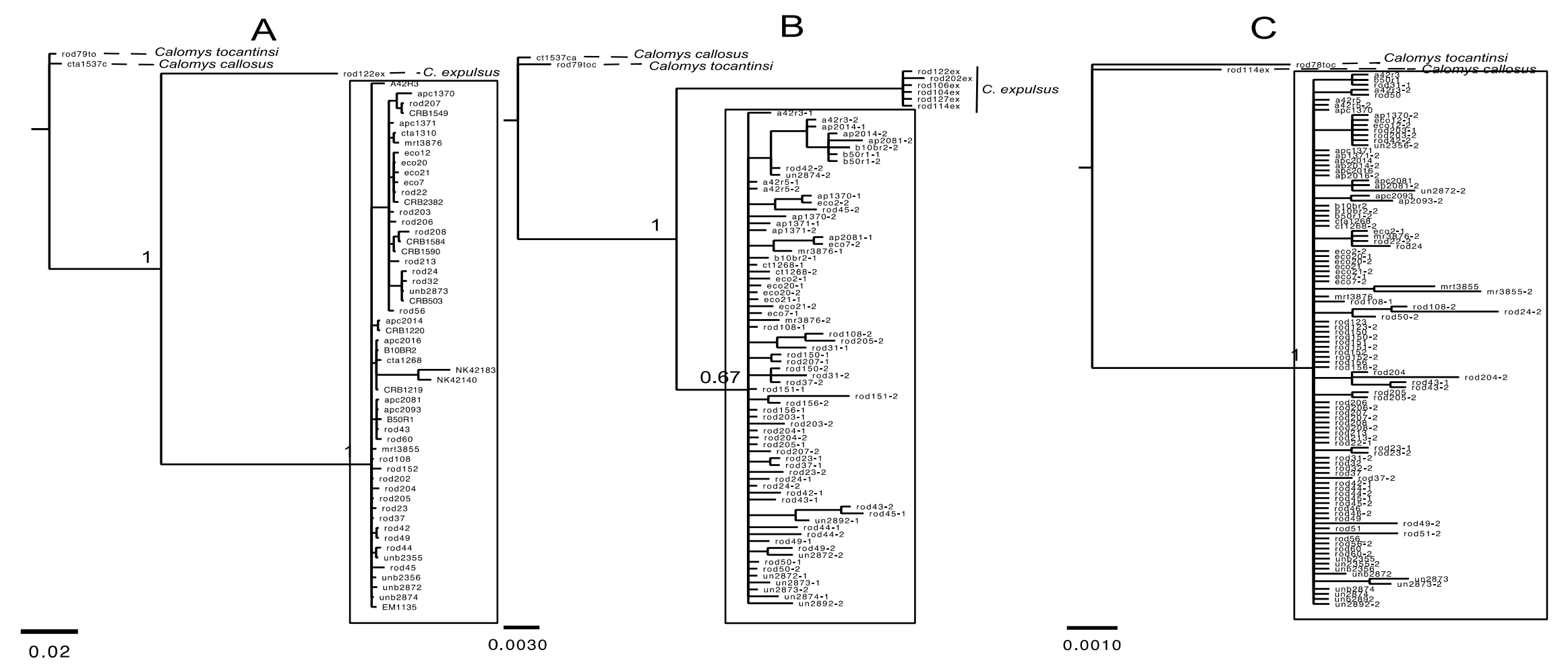

Figura 4.3: Filogenias resultantes da análise bayesianas com base em sequências do cyt-b (A), ADH (B) e Bfib (C). Retângulos indicam exemplares de Calomys tener (grupo interno). Probabilidade posterior (pp) para o monofiletismo de C. tener: $\mathrm{pp}=1 \mathrm{para}$ cyt-b e ADH e pp=0.67 Bfib. 


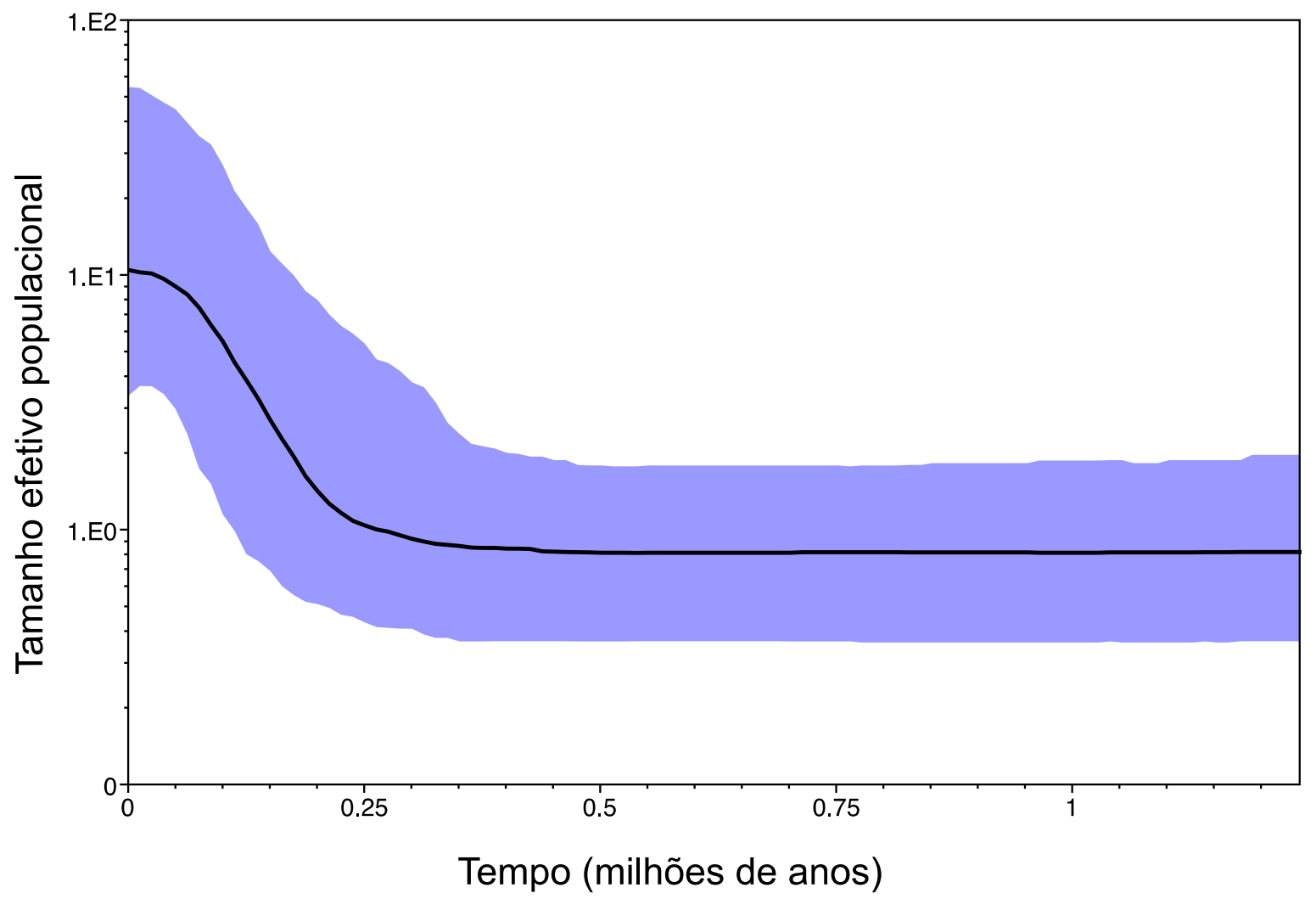

Figura 5.3: Tamanho efetivo populacional através do tempo estimado com sequências do cyt-b de $C$. tener com base em Bayesian Skyline Plots. Área em azul representa intervalo de $95 \%$ de HPD. 


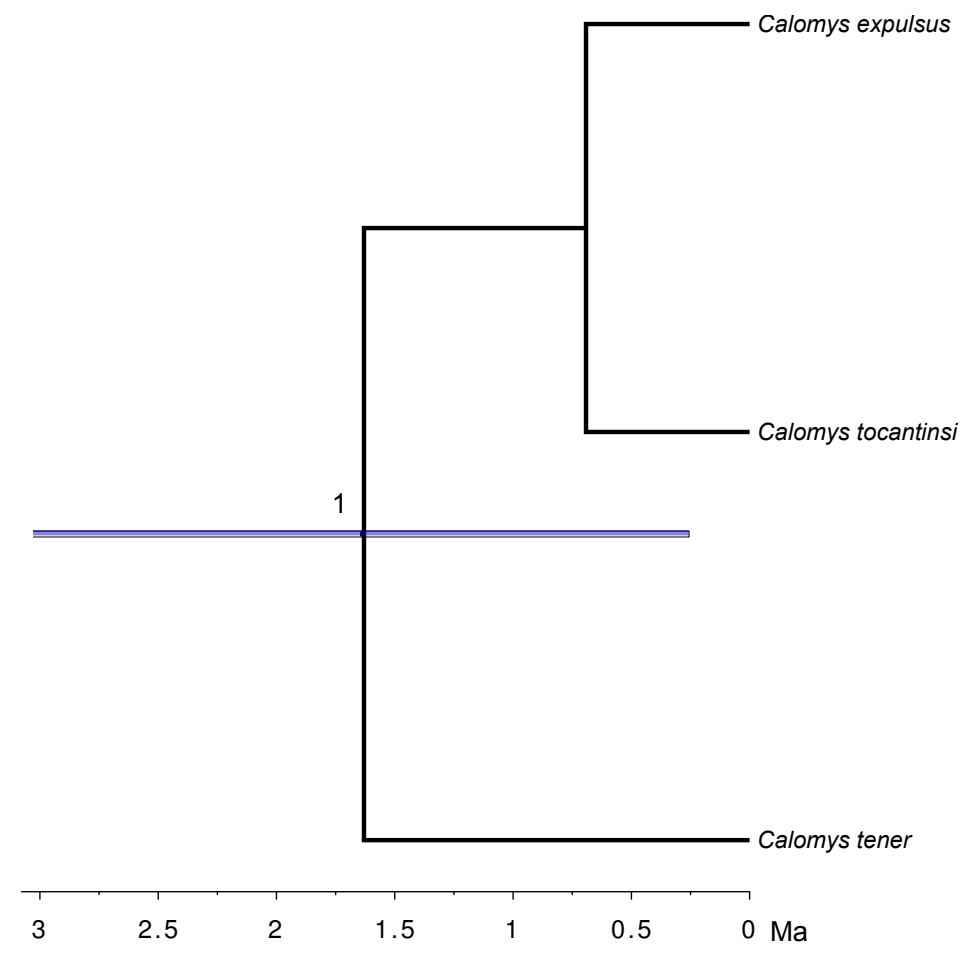

Figura 6.3: Árvore de espécies utilizando sequências de todos os marcadores (cyt-b, ADH e Bfib) e datação molecular. Número próximo ao nó significa probabilidade posterior. Probabilidade abaixo de 0,9 não apresentada.

Tabela 1.3: Valores das estatísticas $D$ de Tagima, $F s$ de Fu e $R_{2}$ de Ramos-Onsins e Rozas, que testam desvios do modelo neutro de evolução. Asterisco indica probabilidade $<0,05$.

\begin{tabular}{llll}
\hline Gene & $D$ & $F s$ & $R_{2}$ \\
\hline Cyt-b & $-1.58^{*}$ & $-17.31^{*}$ & $0.05^{*}$ \\
ADH & $-2.57^{*}$ & $-29.33^{*}$ & $0.02^{*}$ \\
Bfib & -1.05 & -64.01 & $0.06^{*}$ \\
\hline
\end{tabular}




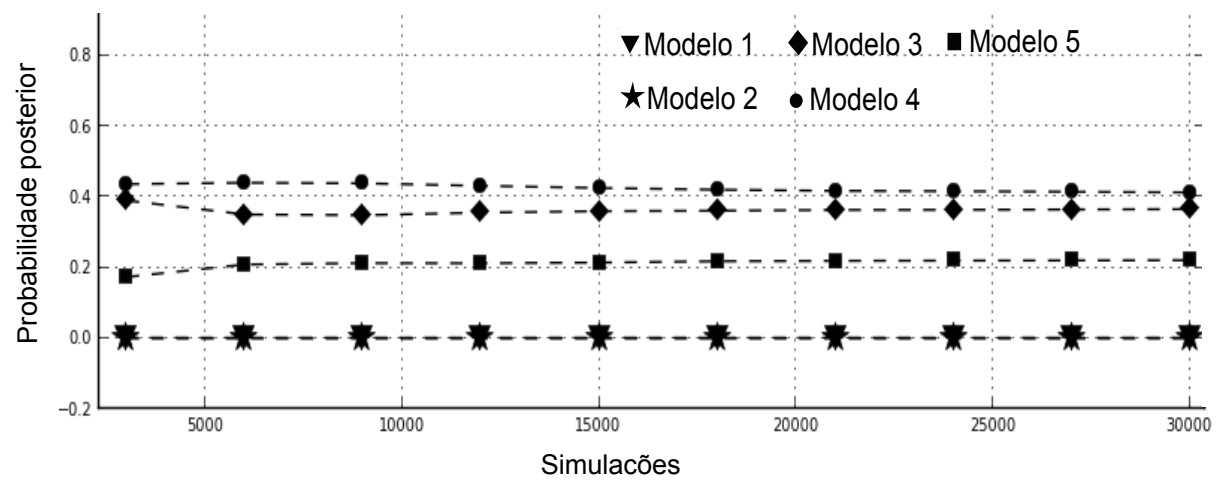

Figura 7.3: Plots do algoritmo de regressão logística para cada cenário demográfico estimado no programa DIYABC. Modelos 3 e 4 com maiores valores de probabilidade posterior. 


\section{Discussão}

Nenhuma análise implementada no presente estudo demonstrou algum tipo de estruturação geográfica ou genética em populações de C. tener. Assim, pode-se sustentar que esta espécie é resultante de uma radiação rápida, onde uma linhagem expande sua distribuição geográfica em um curto espaço de tempo. Alternativamente, é possível sugerir que contatos secundários possam ter ocorrido entre populações anteriormente isoladas reestabelecendo assim o fluxo gênico. Ambos cenários evolutivos podem ser explicados da seguinte forma com base nos resultados obtidos no presente estudo: a linhagem de $C$. tener surgiu por volta de 1,7 milhões de anos atrás derivada de um ancestral adaptado para viver em habitats abertos (assim como todos os representantes da tribo Phyllotini - Salazar-Bravo et al. 2013); (1) ocupou a região atual do Cerrado com baixa densidade populacional até a intensificação das queimadas (32.000 anos atrás, Ledru 2002) e a presença do homem há 12.000 anos atrás (Barbosa \& Schmitz 2008) que permitiram uma colonização rápida de novos habitats disponíveis; ou (2) ocupou a região atual do Cerrado em várias populações isoladas e a intensificação de queimadas (32.000 anos atrás, Ledru 2002) e a presença do homem (12.000 anos atrás, Barbosa \& Schmitz 2008) permitiu a conexão dos habitats propícios para a ocorrência de C. tener, reestabelecendo o fluxo gênico entre as populações.

Não existem estudos biogeográficos de vertebrados no Cerrado que testem a influência de queimadas e a presença humana como fatores determinantes para a diversificação dos organismos. Este assunto parece ser subestimado frente a diversos indicadores de que queimadas naturais e provocadas pelo homem tem papel determinante como força evolutiva (Bond \& Keeley 2005; Keeley et al. 2011). No Brasil, pesquisas indicam que organismos vegetais com especiação in situ no Cerrado demonstram adaptações fisiológicas e anatômicas para tolerar o stress de queimadas (Simon \& Pennington 2012). Além disso, a própria fisionomia da paisagem do Cerrado é dramaticamente alterada sob diferentes regimes de queima (Coutinho 1982; Eiten 1972; Oliveira-Filho \& Ratter 2002). Diante do efeito do fogo, vertebrados exibem diferentes respostas ecológicas em termos de composição e abundância de espécies (Briani et al. 2004; Henriques et al. 2007; Pantoja 2007). Em uma perspectiva histórica, o fogo tem efeito direto na evolução e distribuição de mamíferos pastadores em áreas de campos e pradarias (Anderson 2006). Adicionalmente, o componente antrópico é outro causador de fogo que deve ser 
mencionado, visto que a produção de fogo é uma das primeiras ferramentas que humanos pré-históricos utilizaram para alterar seus habitats (Bowman et al. 2011). Em savanas da Austrália há registros de uso do fogo pelo povo aborígene desde 4.000 anos atrás (Bowman 1998), enquanto no Brasil povos indígenas queimam áreas naturais até os dias de hoje (Mistry et al. 2005). Neste contexto, é certo que a influência do fogo sobre os organismos distribuídos no Cerrado não pode ser ignorada em estudos biogeográficos históricos.

Uma série de estudos que propõem cenários paleoambientais com base em registros palinológicos, de carvão vegetal e arqueológicos estão disponíveis. Como exemplo, Behling $(1995,2003)$ sugere que no começo do Holoceno uma região a apenas $250 \mathrm{~km}$ da costa do Brasil era caracterizada por formação vegetal savânica e frequentemente atingida por fogo. Bueno et al. (2013) por sua vez, indicam uma série de sítios do Brasil central com registros de assentamentos de humanos pré-históricos e registros de carvão vegetal desde o final do Pleistoceno até o Holoceno recente. $\mathrm{Na}$ mesma direção, Gouveia et al. (2002) sugerem a ocorrência frequente de fogo numa região do centro-oeste do Brasil durante o Holoceno médio, enquanto que ao norte do Maranhão uma vegetação de savana e registro de fogo são conhecidos durante o Holoceno tardio/médio (Pessenda et al. 2004). Essa fração de estudos selecionados demonstram uma série de registros de fogo e ocupações humanas pré-históricas que faziam uso de queimadas durante o final do Pleistoceno e durante todo Holoceno. Frente a tais evidências, é razoável que a ocorrência de fogo deva ser levada em conta para a formulação de hipóteses sobre história demográfica e biogeografia histórica de organismos de diversificação recente, assim como realizado no presente estudo.

Um conjunto de evidências obtidas no presente estudo sugerem que $C$. tener teve um aumento demográfico considerável durante o Quaternário tardio. Sugere-se que a presença de fogo no Cerrado em períodos secos e a presença humana neste bioma possam ter sido fatores determinantes para o crescimento demográfico da espécie. Por fim, chama-se a atenção de que este é o primeiro estudo a testar modelos demográficos, com base em métodos de $A B C$, em conjunto como o potencial efeito de queimadas sobre a evolução de pequenos mamíferos no Cerrado. Fenômenos associados a atividade humana, como as queimadas em regiões naturais suscetíveis, como o Cerrado, e a presença de tribos humanas pré-históricas devem ser considerados em hipóteses biogeográficas históricas. 


\section{Referências bibliográficas}

Amman, B. R., Hanson, J. D., Longhofer, L. K. \& Bradley, R. D. (2006). Intron 2 (ADH1-I2) of the alcohol dehydrogenase gene: a nuclear DNA marker for mammalian systematics. Occasional Papers, Museum of Texas Tech University, 256, $1-16$.

Anderson, R. C. (2006). Evolution and origin of the Central Grassland of North America: climate, fire, and mammalian grazers. Journal of the Torrey Botanical Society, 133, 626-647.

Bandelt, H. J., Forster, P., \& Röhl, A. (1999). Median-joining networks for inferring intraspecific phylogenies. Molecular Biology and Evolution, 16, 37-48.

Barbosa, A. S., \& Schimitz, P. I. (1998). Ocupação indígena no Cerrado: esboço de uma história. In S. SANO \& S. ALMEIDA (Eds). Cerrado: ambiente e flora. Brasília: EMBRAPA-CPAC, 3-45.

Beaumont, M. A., Zhang, W., \& Balding, D. J. (2002). Approximate bayesian computation in gopulation Genetics. Genetics, 162, 2025-2035.

Behling, H. (1995). A high resolution Holocene pollen record from Lago do Pires, SE Brazil: vegetation, climate and fire history. Journal of Paleontology, 14, 253268.

Behling, H. (2003). Late glacial and Holocene vegetation, climate and fire history inferred from Lagoa Nova in the southeastern Brazilian lowland. Vegetation History Archaeobotany, 12, 263-270.

Bond, W. J., \& Keeley, J. E. (2005). Fire as a global "herbivore": the ecology and evolution of flammable ecosystems. TRENDS in Ecology and Evolution Vol.20, 20, 387-394.

Bonvicino, C. R., Oliveira, J. A. D. \& D’Andrea, P. S. (2008). Guia dos roedores do Brasil, com chaves para gêneros baseadas em caracteres externos. Rio de Janeiro: Centro Pan-Americano de Febre Aftosa-OPAS/OMS, 120.

Bouckaert, R., Heled, J., Kuhnert, D., Vaughan, T., Wu, C., Xie, D., ... Drummond, A. J. (2014). BEAST 2: A software platform for bayesian evolutionary analysis. Plos Computational Biology, 10, 1-6.

Bowman, D. M. J. S. (1998). Tansley Review No. 101. The impact of Aboriginal landscape burning on the Australian biota. New Phytologist, 140, 385-410.

Bowman, D. M. J. S., Balch, J., Artaxo, P., Bond, W. J., Cochrane, M. A., Antonio, C. M. D., ... Swetnam, T. W. (2011). The human dimension of fire regimes on 
Earth. Journal of Biogeography, 38, 2223-2236.

Briani, D. C., Palma, A. R. T., Vieira, E. M., \& Henriques, R. P. B. (2004). Post-fire succession of small mammals in the Cerrado of central Brazil. Biodiversity and Conservation, 13, 1023-1037.

Bueno, L., Dias, A. S., \& Steele, J. (2013). The late Pleistocene/early Holocene archaeological record in Brazil: a geo-referenced database. Quaternary International, 301, 74-93.

Cole, M. M. (1960). Cerrado, Caatinga and Pantanal: the distribution and origin of the savanna vegetation of Brazil. The Geographical Journal, 126, 168-179.

Corander, J., Marttinen, P., Sirén, J., \& Tang, J. (2008). Enhanced Bayesian modelling in BAPS software for learning genetic structures of populations. BMC Bioinformatics, 9, 1-14.

Cornuet, J., Pudlo, P., Veyssier, J., Dehne-Garcia, A., Gautier, M., Leblois, R., ... Estoup, A. (2014). DIYABC v2.0: a software to make approximate Bayesian computation inferences about population history using single nucleotide polymorphism, DNA sequence and microsatellite data. Bioinformatics, 30, 1187-1189.

Costa, B. M. (2011). Queimadas e lagartos do Cerrado: efeitos diretos e indiretos. Dissertação de Mestrado, Universidade de Brasília, Brasília - Distrito Federal.

Coutinho, L. M. (1982). Fire in the Ecology of the Brazilian Cerrado. In J. G. Goldammer (Ed.), Fire in the Tropical Biota: Ecosystem Processes and Global Challenges (pp. 82-105). Berlin, Heidelberg: Springer Berlin Heidelberg.

Darriba, D., Taboada, G.L., Doallo, R. \& Posada, D. (2012) Darriba, D., Taboada, G.L., Doallo, R. \& Posada, D. (2012) jModelTest 2: more models, new heuristics and parallel computing. Nature Methods, 9, 772-772.

Edgar, R.C. (2004). MUSCLE: a multiple sequence alignment method with reduced time and space complexity. BMC Bioinformatics, 32, 1792-1797.

Eiten, G. (1972). The Cerrado vegetation of Brazil. Botanical Review, 38, 201-341.

Freire, G. de B. (2010). A influência de diferentes regimes de queima sobre a comunidade de aranhas cursoriais do cerrado de Brasília/DF. Tese. Universidade de Brasília.

Fu, Y. X. (1997). Statistical Tests of Neutrality of Mutations against Population Growth, Hitchhiking and Background Selection. Genetics, 147, 915-925.

Gouveia, S. E. M., Pessenda, L. C. R., Aravena, R., Boulet, R., Scheel-Ybert, R., Bendassoli, J. A., ... Freitas, H. A. (2002). Carbon isotopes in charcoal and soils 
in studies of paleovegetation and climate changes during the late Pleistocene and the Holocene in the southeast and centerwest regions of Brazil. Global and Planetary Change, 33, 95-106.

Guarnizo, C. E., Werneck, F. P., Giugliano, L. G., Santos, M. G., Fenker, J., Sousa, L., .. Colli, G. R. (2016). Cryptic lineages and diversification of an endemic anole lizard (Squamata, Dactyloidae) of the Cerrado hotspot. Molecular Phylogenetics and Evolution, 94, 279-289.

Gutiérrez, E. E., Anderson, R. P., Voss, R. S., Ochoa-G, J., Aguilera, M., \& Jansa, S. A. (2014). Phylogeography of Marmosa robinsoni: insights into the biogeography of dry forests in northern South America. Journal of Mammalogy, 95, 1175-1188.

Hasegawa, M., Kishino, K., \& Yano, T.(1985). Dating the human-ape splitting by a molecular clock of mitochondrial DNA. Journal of Molecular Evolution 22, $160-174$.

Heled, J., \& Drummond, A. J. (2010). Bayesian inference of species trees from multilocus data. Molecular Biology and Evolution, 27, 570-580.

Henriques, R. P. B., Briani, D. C., Palma, A. R. T., \& Vieira, E. M. (2007). A simple graphical model of small mammal succession after fire in the Brazilian cerrado/Un modèle graphique simple de repeuplement par les petits mammifères du cerrado brésilen après brûlis, 70, 226-230.

Huelsenbeck, J.P. \& Ronquist, F. (2001) MRBAYES: Bayesian inference of phylogeny. Bioinformatics, 17, 754-755.

Keeley, J. E., Pausas, J. G., Rundel, P. W., Bond, W. J., \& Bradstock, R. A. (2011). Fire as an evolutionary pressure shaping plant traits. Trends in Plant Science, 16, 406-411.

Kumar, S., \& Subramanian, S. (2002). Mutation rates in mammalian genomes. Proceedings of National Academy Society, 99, 803-808.

Ledru, M.-P. (2002). Late Quaternary history and evolution of the cerrados as revealed by palynological records. In S. O. Oliveira \& R. J. Marquis (Eds.), The cerrados of Brazil: ecology and natural history of a neotropical savanna (pp. 33-50). New York, NY.

Ledru, M.-P., Salgado-labouriau, L., \& Lorscheitter, L. (1998). Vegetation dynamics in southern and central Brazil during the last 10,000 yr B.P. Review of Palaeobotanuy and Palynology, 99, 131-142. 
Leigh, J. W. \& Bryant, D. (2015). PopART: full-feature software for haplotype network construction. Methods in Ecology and Evolution, 6, 1110-1116.

Librado, P., \& Rozas, J. (2009). DnaSP v5 : a software for comprehensive analysis of DNA polymorphism data. Bioinformatics, 25, 1451-1452.

Mistry, J., Berardi, A., Andrade, V., Txicaprô, K., Phocrok, K., \& Leonardos, O. (2005). Indigenous Fire Management in the cerrado of Brazil: The Case of the Krahô of Tocantins. Human Ecology, 33, 365-386.

Nascimento, F. F. Do, Pereira, L. G., Geise, L., Bezerra, A. M. R., D’Andrea, P. S., \& Bonvicino, C. R. (2011). Colonization process of the Brazilian common vesper mouse, Calomys expulsus (Cricetidae, Sigmodontinae): a biogeographic hypothesis. The Journal of Heredity, 102, 260-268.

Nascimento, F. F., Lazar, A., Menezes, A. N., Durans, A. D. M., Moreira, J. C., Salazar-Bravo, J., ... Bonvicino, C. R. (2013). The Role of Historical Barriers in the Diversification Processes in Open Vegetation Formations during the Miocene/Pliocene Using an Ancient Rodent Lineage as a Model. PloS One, 8, 113.

Oliveira-Filho, A. T., \& Ratter, J. T. (2002). Vegetation physiognomies and woody flora o the cerrado biome. In P. S. Oliveira \& R. J. Marquis (Eds.), The Cerrados of Brazil, ecology and natural history of a neotropical savanna (pp. 91-120). New York, NY: Columbia University Press.

Pantoja, D. L. (2007). Efeitos do fogo sobre a taxocenose de lagartos em áreas de Cerrado. Tese. Universidade de Brasília.

Pessenda, L. C. R., Ribeiro, A. de S., Gouveia, S. E. M., Aravena, R., Boulet, R., \& Bendassolli, J. A. (2004). Vegetation dynamics during the late Pleistocene in the Barreirinhas region, Maranhão State, northeastern Brazil, based on carbon isotopes in soil organic matter. Quaternary Research, 62, 183-193.

Rambaut, A. \& Drummond, A.J. (2007) Tracer. Ver. 1.4. Available from: http://beast.bio.ed.ac.uk/Tracer (accessed 1 November 2013)

Ramos-Onsins, S. E. \& Rozas, J. (2002). Statistical Properties of New Neutrality Tests Against Population Growth. Molecular Biology and Evolution, 19, 20922100.

Salazar-Bravo, J., Pardiñas, U. F. J., \& D’Elía, G. (2013). A phylogenetic appraisal of Sigmodontinae (Rodentia, Cricetidae) with emphasis on phyllotine genera: systematics and biogeography. Zoologica Scripta, 42, 250-261.

Simon, M. F., \& Pennington, T. (2012). Evidence for adaptation to fire regimes in the 
tropical savannas of the Brazilian Cerrado. International Journal of Plant Sciences, 173, 711-723.

Smith, M. F., \& Patton, J. L. (1993). The diversification of South American murid rodents: evidence from mitochondrial DNA sequence data for the akodontine tribe. Biological Journal of the Linnean Society, 50, 149-177.

Stephens M, Smith N. J., \& Donnelly, P. (2001) A new statistical method for haplotype reconstruction from population data. The American Journal of Human Genetics, 68, 978-989.

Tajima, F. (1989). Statistical Method for Testing the Neutral Mutation Hypothesis by DNA Polymorphism. Genetics, 123, 585-595.

Tamura, K., Peterson, D., Peterson, N., Stecher, G., Nei, M. \& Kumar, S. (2011) MEGA5: molecular evolutionary genetics analysis using maximum likelihood evolutionary distance, and maximum parsimony methods. Molecular Biology and Evolution, 28, 2731-2739.

Vieira, E. M., \& Marinho Filho, J. (1998). Pre- and post-fire habitat utilization by rodents of Cerrado from central Brazil. Biotropica, 30, 491-496.

Wickliffe, J. K., Hoffman, F. G., Carroll, D. S., Dunina-Barkovs- kaya, Y. V., Bradley, R. D. \& Baker, R. J. (2003). Intron 7 (Fgb-i7) of the Fibrinogen, B Beta Polypeptide (Fgb): a nuclear DNA phylogenetic marker for mammals. Occasional Papers, Museum of Texas Tech University, 219, 1-6. 
Anexo 1.3: Lista dos exemplares de $C$. tener utilizados nas análises incluindo a identificação da amostra (número de tombo, de coleta ou de acesso ao GenBank), localidade e coordenadas geográficas. São apresentados ainda as informações relativas às espécies utilizadas como grupo externo.

\begin{tabular}{|c|c|c|c|c|}
\hline \multirow{2}{*}{$\begin{array}{l}\text { Identificação da } \\
\text { amostra }\end{array}$} & \multirow{2}{*}{$\begin{array}{l}\text { Localidade } \\
\text { Anhembi }\end{array}$} & \multirow{2}{*}{$\begin{array}{l}\text { Estado } \\
\mathrm{SP}\end{array}$} & \multicolumn{2}{|c|}{ Coordenadas } \\
\hline & & & -22.78621 & -48.13119 \\
\hline APC1370 & Rio da Conceição & TO & -11.32091 & -46.78655 \\
\hline APC1371 & Rio da Conceição & TO & -11.32091 & -46.78655 \\
\hline APC2014 & São Carlos & $\mathrm{SP}$ & -21.97507 & -47.87897 \\
\hline APC2016 & São Carlos & SP & -21.97507 & -47.87897 \\
\hline APC2081 & São Carlos & SP & -21.97507 & -47.87897 \\
\hline APC2093 & São Carlos & $\mathrm{SP}$ & -21.97507 & -47.87897 \\
\hline B10BR2 & Bofete & SP & -23.10712 & -23.10712 \\
\hline B50R1 & Bofete, & $\mathrm{SP}$ & -23.10712 & -23.10712 \\
\hline UFES-CTA 1268 & Nova Ponte & MG & -19.22538 & -47.703761 \\
\hline UFES-CTA 1310 & Nova Ponte & MG & -19.22538 & -47.703761 \\
\hline eco12 & Rio das Mortes & MT & -14.77937 & -52.661249 \\
\hline eco20 & Rio das Mortes & MT & -14.77937 & -52.661249 \\
\hline eco21 & Rio das Mortes & MT & -14.77937 & -52.661249 \\
\hline eco07 & Rio das Mortes & MT & -14.77937 & -52.661249 \\
\hline MRT 3855 & Paranã & TO & -12.63331 & -47.85550 \\
\hline MRT 3876 & Paranã & TO & -12.63331 & -47.85550 \\
\hline ROD 108 & Fazenda Trijunção & BA & -14.88291 & -45.94247 \\
\hline ROD 152 & PARNA Chapada dos Veadeiros & GO & -14.03844 & -47.62379 \\
\hline ROD 202 & PARNA Chapada dos Veadeiros & GO & -14.03844 & -47.62379 \\
\hline ROD 203 & PARNA Chapada dos Veadeiros & GO & -14.03844 & -47.62379 \\
\hline ROD 204 & PARNA Chapada dos Veadeiros & GO & -14.03844 & -47.62379 \\
\hline ROD 205 & PARNA Chapada dos Veadeiros & GO & -14.03844 & -47.62379 \\
\hline ROD 206 & Parque Estadual Terra Ronca & GO & -13.61543 & -46.38954 \\
\hline ROD 207 & Parque Estadual Terra Ronca & GO & -13.61543 & -46.38954 \\
\hline ROD 208 & Parque Estadual Terra Ronca & GO & -13.61543 & -46.38954 \\
\hline ROD 213 & PARNA Chapada da Mesas & MA & -7.2402 & -47.143 \\
\hline ROD 22 & PARNA de EMAS & GO & -18.25405 & -52.75162 \\
\hline ROD 23 & PARNA de EMAS & GO & -18.25405 & -52.75162 \\
\hline
\end{tabular}


Anexo 1.3: Continuação

\begin{tabular}{|c|c|c|c|c|}
\hline \multirow{2}{*}{$\begin{array}{l}\text { Número } \\
\text { ROD } 24\end{array}$} & \multirow{2}{*}{$\begin{array}{l}\text { Localidade } \\
\text { PARNA de EMAS }\end{array}$} & \multirow{2}{*}{$\begin{array}{l}\text { Estado } \\
\text { GO }\end{array}$} & \multicolumn{2}{|c|}{ Coordenadas } \\
\hline & & & -18.25405 & -52.75162 \\
\hline ROD 32 & PARNA de EMAS & GO & -18.25405 & -52.75162 \\
\hline ROD 37 & PARNA de EMAS & GO & -18.25405 & -52.75162 \\
\hline ROD 42 & PARNA Serra da Canastra & MG & -20.29740 & -46.52211 \\
\hline ROD 43 & PARNA Serra da Canastra & MG & -20.29740 & -46.52211 \\
\hline ROD 44 & PARNA Serra da Canastra & MG & -20.29740 & -46.52211 \\
\hline ROD 45 & PARNA Serra da Canastra & MG & -20.29740 & -46.52211 \\
\hline ROD 49 & PARNA Serra da Canastra & MG & -20.29740 & -46.52211 \\
\hline ROD 50 & PARNA Serra da Canastra & MG & -20.29740 & -46.52211 \\
\hline ROD 51 & PARNA Serra da Canastra & MG & -20.29740 & -46.52211 \\
\hline ROD 56 & PARNA Serra da Canastra & MG & -20.29740 & -46.52211 \\
\hline ROD 60 & PARNA Serra da Canastra & MG & -20.29740 & -46.52211 \\
\hline UNB2355 & PARNA Serra da Canastra & MG & -20.29740 & -46.52211 \\
\hline UNB2356 & PARNA Serra da Canastra & MG & -20.29740 & -46.52211 \\
\hline UNB2872 & Catalão & GO & -17.80908 & -47.74128 \\
\hline UNB2873 & Catalão & GO & -17.80908 & -47.74128 \\
\hline UNB2874 & Catalão & GO & -17.80908 & -47.74128 \\
\hline AF385597 & Tupi Paulista & SP & -21.3829 & -51.5754 \\
\hline AF385596 & Tupi Paulista & SP & -21.3829 & -51.5754 \\
\hline DQ447301 & Jaborandi & $\mathrm{BA}$ & -14.0716 & -45.4498 \\
\hline DQ447300 & Jaborandi & BA & -14.0716 & -45.4498 \\
\hline DQ447298 & Jaborandi & $\mathrm{BA}$ & -14.0716 & -45.4498 \\
\hline DQ447297 & Pedreira & SP & -22.7418 & -46.8952 \\
\hline DQ447296 & Pedreira & SP & -22.7418 & -46.8952 \\
\hline DQ447295 & Corumbá de Goiás & GO & -15.9249 & -48.8121 \\
\hline DQ447294 & Campinas & $\mathrm{SP}$ & -22.9098 & -47.0625 \\
\hline DQ447302 & Mimoso de Goiás & GO & -15.0588 & -48.1620 \\
\hline Grupo externo & Número GenBank, tombo ou & & & \\
\hline Calomys callosus & UFES-CTA 1537 & & & \\
\hline Calomys tocantinsi & ROD 78,79 & & & \\
\hline Calomys expulsus & ROD $114,122,106,104,127$ & & & \\
\hline
\end{tabular}

Acrônimos Anexo 1: UFES-CTA: coleção de tecidos animais da Universidade

Federal do Espírito Santo; ROD: coleção de tecidos de mamíferos do Laboratório de 
Genética e Biodiversidade da Universidade de Brasília; eco: coleção do autor (a ser depositada na Coleção de Mamíferos da UnB); UNB: coleção de mamíferos da Universidade de Brasília; A42R3, B10BR2, B50R1, MRT e APC: caderno de campo de Ana Paula Carmignotto.

Anexo 2.3: Nome e sequências dos iniciadores utilizados no estudo, indicando referencias que delinearam os iniciadores.

\begin{tabular}{|c|c|c|}
\hline Primer & Sequência & Referência \\
\hline $\begin{array}{l}\mathrm{ADH} 2340- \\
\text { I }\end{array}$ & 5' GTAATCAAGTGCAAAGCAGCTG & Amman et al. 2006 \\
\hline $\begin{array}{l}\text { ADH2340- } \\
\text { II }\end{array}$ & 5' TAACCACGTGGTCATCTGAGCG & Amman et al. 2006 \\
\hline $\mathrm{Fgb}-17 \mathrm{U}$ & $\begin{array}{l}\text { 5'- } \\
\text { GGGGAGAACAGAACCATGACCATCCAC }\end{array}$ & Wickiffe et al. 2003 \\
\hline Fgb-17L & $\begin{array}{l}\text { 5'- } \\
\text { ACCCCAGTAFTATCTGCCATTCGGATT }\end{array}$ & Wickiffe et al. 2003 \\
\hline MVZ05 & $\begin{array}{l}\text { 5'- } \\
\text { CGAAGCTTGATATGAAAAACCATCGTTG }\end{array}$ & $\begin{array}{l}\text { Smith \& Patton } \\
1993\end{array}$ \\
\hline MVZ16 & $\begin{array}{l}\text { 5'- } \\
\text { AAATAGGAARTATCAYTCTGGTTTRAT }\end{array}$ & $\begin{array}{l}\text { Smith \& Patton } \\
1993\end{array}$ \\
\hline
\end{tabular}




\section{CONSIDERAÇÕES FINAIS}

Os dados aqui apresentados indicam que organismos distribuídos em diferentes fitofisionomias do Cerrado e Caatinga sofreram eventos de diversificação situados em períodos históricos distintos. Por exemplo, eventos cladogenéticos que levaram a episódios de especiação em Phyllomys foram reconhecidos durante o Mioceno, Plioceno e Pleistoceno, correspondendo a aproximadamente um período entre 10 milhões e 12 mil anos atrás. Por outro lado, populações de Gracilinanus agilis apresentam expansão populacional durante o último 1 milhão de anos, enquanto que populações de Calomys tener parecem sofrer eventos de expansão nos últimos 32 mil anos até o presente.

Estes resultados sugerem que as fitofisionomias que formam um mosaico no Cerrado evoluíram de maneira independente ao longo do tempo, indicando que episódios geológicos, climáticos e antrópicos tem implicações particulares para cada fitofisionomia. Tendo em vista que cada fitofisionomia é única em termos de habitats disponíveis, as linhagens de organismos que nelas habitam sofrem de maneira desigual diante das pressões evolutivas. Isto fica mas claro se supormos que as matas de galeria, habitat de espécies de Phyllomys, expandiram em momentos históricos mais úmidos, permitindo o contato entre matas de galerias do cerrado e biomas florestais adjacentes e ocasionando trocas faunísticas. As matas secas por outro lado, estão distribuídas em algumas regiões estáveis ao longo do tempo e outras menos estáveis, implicando no isolamento de diferentes populações de G. agilis típicas deste ambiente. Por último, eventos de queimadas são mais frequentes em habitats abertos, como os campos e cerrados onde encontram-se populações de $C$. tener e, portanto, um crescimento demográfico nas populações desta espécie, conhecida por colonizr áreas recém queimadas, é esperado a partir do momento em que as queimadas ficaram mais frequentes no Cerrado.

Por fim, a presente tese contribui com novas hipóteses biogeográficas para o Cerrado e Caatinga, algumas das quais implicam em relações com os biomas vizinhos, Amazônia e Floresta Atlântica. Além disso, é proposto que os ambientes considerados secos do interior do Brasil abrigam espécies ainda desconhecidas da ciência, e que a diversidade destes ambientes é apenas marginalmente conhecida. Sendo assim, é demanda evidente que mais estudos biogeográficos, de sistemática e taxonômicos sejam conduzidos nos sistemas naturais do interior do Brasil, principalmente diante do cenário atual de acelerada destruição de habitas e formações naturais. 